Aus der Abteilung Medizinische Mikrobiologie

(Prof. Dr. med. U. Groß)

im Zentrum Hygiene und Humangenetik

der Medizinischen Fakultät der Universität Göttingen

\title{
Stamm- und wirtszellabhängige Apoptose-Induktion durch Campylobacter jejuni
}

\author{
INAUGURAL - DISSERTATION \\ zur Erlangung des Doktorgrades \\ der Medizinischen Fakultät \\ der Georg-August-Universität zu Göttingen
}

vorgelegt von

Friedrich Schöttelndreier

aus

Stadthagen

Göttingen 2011 
Dekan:

1. Berichterstatter:

2. Berichterstatter/in:

3. Berichterstatter/in:

Tag der mündlichen Prüfung:
Prof. Dr. med. C. Frömmel

Prof. Dr. med. U. Groß

Prof. Dr. biol. hum. M. Schön

Prof. Dr. med. M. Opperman

22. November 2011 


\section{Inhaltsverzeichnis}

Verzeichnis der Abbildungen und Tabellen............................... 5

Abkürzungsverzeichnis......................................................... 6

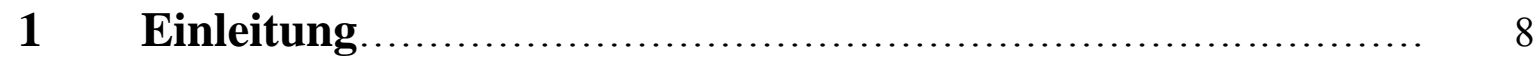

1.1 Campylobacter jejuni - Geschichte und Klassifikation...................... 8

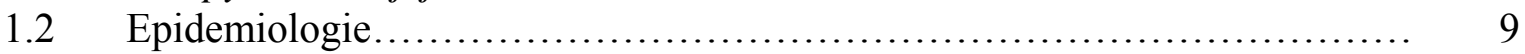

$1.3 \quad$ Ökologie und Infektionswege .......................................... 10

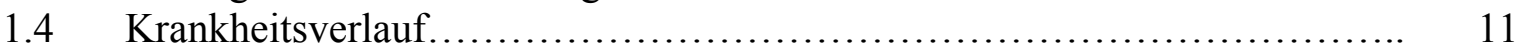

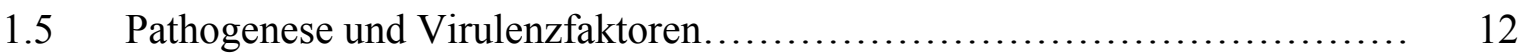

$1.6 \quad$ Cytolethal distending toxin................................................ 14

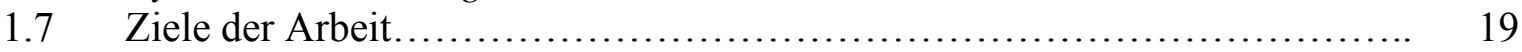

$2 \quad$ Material und Methoden................................................. 21

$2.1 \quad$ Material................................................................... 21

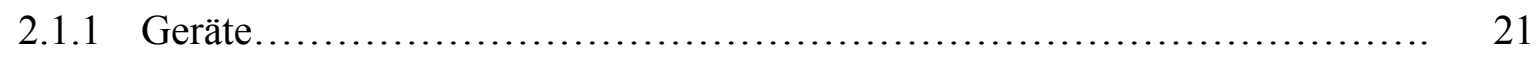

2.1.2 Verbrauchsmaterialien............................................... 22

2.1.3 Zellkultur, Medien und Zusätze........................................... 22

2.1.4 Bakterienkultivierung, Medien und Zusätze................................. 23

2.1.5 Chemikalien, Enzyme, Puffer.............................................. 24

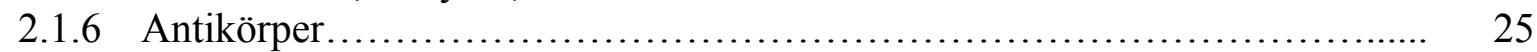

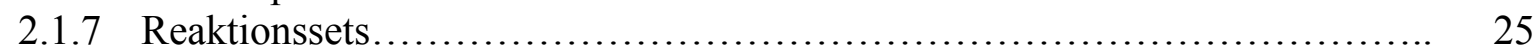

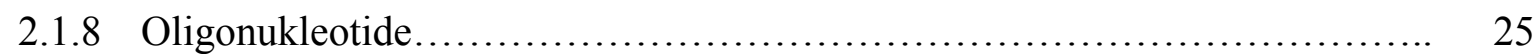

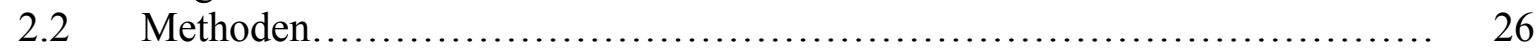

2.2.1 Bakterienkultivierung.................................................. 26

2.2.1.1 Biochemische Charakterisierung ......................................... 26

2.2.1.2 Medien und Wachstumsbedingungen.................................. 26

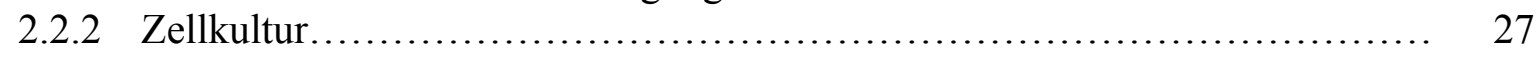

2.2.2.1 Caco-2-Zellen - Medien, Wachstumsbedingungen und Passagierung........... 27

2.2.2.2 Primäre intestinale Hühnerzellen - Medien, Wachstumsbedingungen und

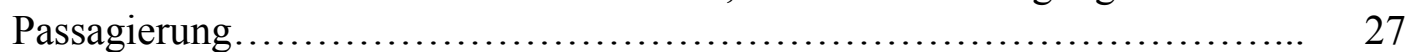

2.2.3 Bestimmung der bakteriellen Invasionseffizienz............................ 28

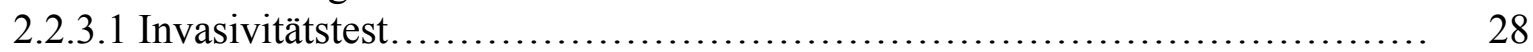

2.2.3.2 Doppelimmunfluoreszenztest............................................ 29

2.2.4 Herstellung des Campylobacter-jejuni-Lysates.............................. $\quad 30$

2.2.5 Apoptoseversuche ....................................................... 31

2.2.5.1 Infektion mit Campylobacter-jejuni-Isolaten................................ 31

2.2.5.2 Inkubation mit Campylobacter-jejuni-Lysat............................... 32

2.2.5.3 Caspase-3-Aktivitätstest................................................... 32

2.2.5.4 Apoptose- und Mitoseuntersuchungen im Doppelimmunfluoreszenztest....... 33

2.2.6 Molekularbiologie......................................................... 34

2.2.6.1 Bakterielle $c d t$-Transkription unter zellfreien Bedingungen.................... 34

2.2.6.2 Kinetik der bakteriellen $c d t$-Transkription nach Infektion..................... 38

2.2.6.3 Bakterielle $c d t$-Transkription nach Infektion verschiedener Wirtszellen........ 39

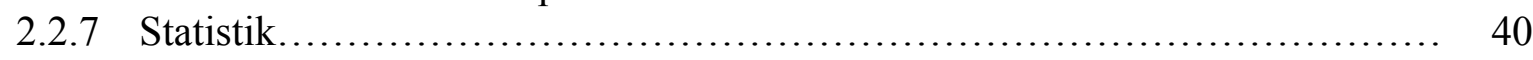

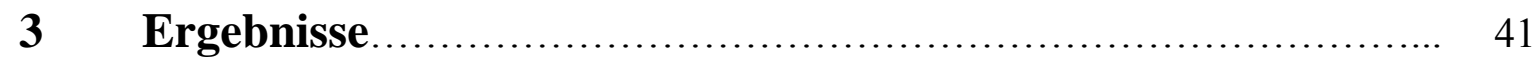

$3.1 \quad$ Invasivitätsexperimente ................................................... 41

3.2 Caspase-3-Aktivitäten nach Infektion...................................... 44

3.3 Caspase-3-Aktivitäten nach Inkubation mit bakteriellem Lysat.................. 47 
3.4 Bestimmung der Mitose- und Apoptose-Raten im Immunfluoreszenzverfahren....................................... 50

3.5 Molekularbiologie - Vergleich der cdt-Transkription unter zellfreien Bedingungen.................................................. 57

3.6 Molekularbiologie - Kinetik der cdt-Transkription nach Infektion....................................................... 60

3.7 Molekularbiologie - Vergleich der $c d t$-Transkription in verschiedenen Wirtszellen.......................................................... 62

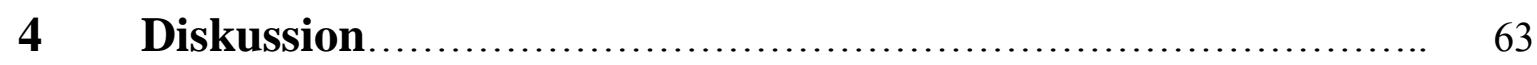

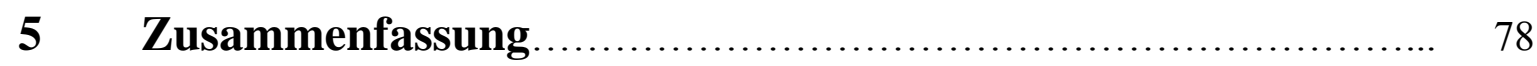

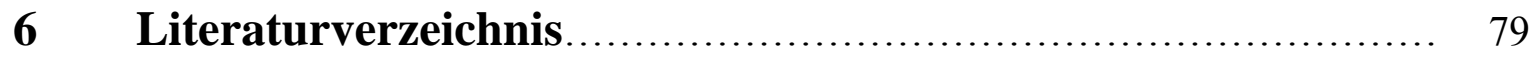




\section{Verzeichnis der Abbildungen und Tabellen}

\section{Abbildungsverzeichnis}

Abbildung 1 Elektronenmikroskopische Darstellung von Campylobacter jejuni..... 8

Abbildung 2 Campylobacter jejuni - Transmissionsmodell.......................... 11

Abbildung 3 Schematische Darstellung von Toxinkomplex, Translokation und zytopathischen Effekten des Cdt.............................. 17

Abbildung 4 Mittelwerte der Invasionseffizienzen (Invasionstest)................ 42

Abbildung 5 Mittelwerte der Invasionseffizienzen (IFT)........................ 43

Abbildung 6 Relative Zellzahlen der infizierten Proben........................... 45

Abbildung 7 Relative Caspase-3-Aktivitäten der infizierten Proben................. 46

Abbildung 8 Inkubation von primären Hühnerdarmzellen mit bakteriellem Lysat.... 48

Abbildung 9 Inkubation von Caco-2-Zellen mit bakteriellem Lysat.................. 49

Abbildung 10 Immunofluoreszenzverfahren, Apoptose- und Mitose-Raten (24h)..... 51

Abbildung 11 Immunofluoreszenzverfahren, Apoptose- und Mitose-Raten (48h)..... 53

Abbildung 12 Beispielhafte fluoreszenz- und phasenkontrastmikroskopische

Aufnahmen der untersuchten Zellen.............................. 57

Abbildung 13 Beispielhafte Darstellung des LightCycler-Analysesoftwareprogramms 58

Abbildung 14 Vergleich der $c d t$-Transkription unter zellfreien Bedingungen........... 59

Abbildung 15 Kinetik der $c d t$-Transkription des Referenzstammes 81-176.......... 60

Abbildung 16 Kinetik der cdt-Transkription des Referenzstammes 81-176

(photometrisch)............................................ 61

\section{Tabellenverzeichnis}

Tabelle $1 \quad$ Verwendete Primernukleotidsequenzen............................... 25

Tabelle $2 \quad$ PCR-Protokolle: Programm 16S.................................. 36

Tabelle 3 PCR-Protokolle: Programme OneStep 16S, OneStep AC und OneStep B 38

Tabelle 4 Mittelwerte der Invasionseffizienzen (Invasionstest).................... 43

Tabelle 5 Anteil apoptotischer und mitotischer Caco-2-Zellen auf Einzelzellebene. 54

Tabelle 6 cdt-Transkription des hochinvasiven Stammes av-518 24h nach Infektion 62 


\section{Abkürzungsverzeichnis}

Abb.

BHI

bp

BSA

${ }^{\circ} \mathrm{C}$

ca.

CDC25C

CDK-1-P

cDNA

Cdt

CHAPS

Chk2

$\mathrm{cm}^{2}$

cp

Cy3

d.h.

DMEM

DMSO

DNA

DNase

EDTA

EIA

ELISA

et al.

FCS

g

$\mathrm{h}$

HEPES

IFT

Ig

$\mathrm{kb}$

$\mathrm{kDa}$

lag

$\log$

$\mathrm{M}$

MEM

$\mathrm{mg}$
Abbildung

Brain Heart Infusion

Basenpaare

bovines Serum-Albumin

Grad Celsius

circa

Protein-Tyrosin-Phosphatase 25 (cell division cycle)

cyclin-dependent kinase 1 (phosphoryliert)

zur RNA komplementäre DNA

Cytolethal distending toxin

Propansulfonat

checkpoint kinase 2

Quadratzentimeter

crossing point

Indocarbocynin

das heißt

Dulbecco's Modified Eagle Medium

Dimethylsulfoxid

Desoxyribonukleinsäure (deoxyribonucleic acid)

Desoxyribonuklease

Ethylendiamintetraacetat

Enzymimmunoassay

Enzyme-linked Immunosorbent Assay

und andere (et alii)

fötales Kälberserum (fetal calf serum)

Formelzeichen für Fallbeschleunigung

Stunde (hora)

N-(2-Hydroxyethyl)Piperazin-N'-(2-Ethansulfonsäure)

Immunfluoreszenztest

Immunglobulin

Kilobasenpaare

Kilo-Dalton

kurze Phase ohne Wachstum, Latenzphase

logarithmisch

molar

Minimum Essential Medium

Milligramm 
Abkürzungsverzeichnis

\begin{tabular}{|c|c|}
\hline $\min$ & Minute \\
\hline $\mathrm{ml}$ & Milliliter \\
\hline $\mathrm{mM}$ & millimolar \\
\hline MOI & Multiplicity of Infection \\
\hline mRNA & messenger-Ribonukleinsäure \\
\hline MUC & Zelloberflächenmuzine \\
\hline$\mu g$ & Mikrogramm \\
\hline$\mu l$ & Mikroliter \\
\hline$\mu \mathrm{m}$ & Mikrometer \\
\hline NEA & Nicht essentielle Aminosäuren \\
\hline OD & optische Dichte \\
\hline OMV's & outer membrane vehicles \\
\hline PARP & Poly(ADP-Ribose)Polymerase (=DNA-Reparaturenzym) \\
\hline PBS & Phosphat-gepufferte Kochsalzlösung \\
\hline PCR & Polymerasekettenreaktion (polymerase chain reaction) \\
\hline PFA & Paraformaldehyd \\
\hline PFGE & pulsed field gel electrophoresis \\
\hline $\mathrm{pH}$ & pondus hydrogenii \\
\hline PIC & protease inhibitor cocktail \\
\hline RNA & Ribonukleinsäure \\
\hline rpm & Umdrehungen pro Minute (engl.: rotations per minute) \\
\hline rRNA & reverse Ribonukleinsäure \\
\hline RT-PCR & Reverse-Transkriptase-PCR \\
\hline s.o. & siehe oben \\
\hline Tab. & Tabelle \\
\hline $\mathrm{U}$ & Unit (Einheit für Enzymaktivität) \\
\hline UV & Ultraviolett \\
\hline v.a. & vor allem \\
\hline vgl. & vergleiche \\
\hline $\mathrm{V}$ & Volt \\
\hline z.B & zum Beispiel \\
\hline
\end{tabular}




\section{$1 \quad$ Einleitung}

\subsection{Campylobacter jejuni - Geschichte und Klassifikation}

Das Genus Campylobacter gehört zur Familie der Campylobacteriaceae und somit zur Klasse der Epsilonproteobacteria und besteht momentan (Stand: April 2010) aus dreißig Spezies und dreizehn Subspezies, welche alle natürliche Bewohner des Intestinaltrakts von Geflügel und warmblütigen Nutztieren sind. Die dortigen mikroaerophilen Bedingungen und hohen Körpertemperaturen stellen ideale Voraussetzungen für ein kontinuierliches Wachstum dieser anspruchsvollen Keime bereit (Abu-Halaweh et al. 2005). Es handelt sich um schlanke, spiralig gekrümmte, gramnegative, nicht sporenbildende Stäbchen von einer Länge zwischen $0,2 \mu \mathrm{m}$ und $0,8 \mu \mathrm{m}$, die durch eine einzige oder multiple polare Flagellen an einem oder beiden Enden (Ursing et al. 1994) eine hohe Beweglichkeit besitzen (Abb.1). Die optimalen Kulturbedingungen liegen bei einem Sauerstoffgehalt der Atmosphäre zwischen 5\% und 10\% und einer Temperatur zwischen $30^{\circ} \mathrm{C}$ und $42^{\circ} \mathrm{C}$, wohingegen der Keim recht empfindlich gegenüber Lagerung bei Raumtemperatur, Trockenheit und oxidativem Stress ist. Es gibt keine einheitlich anerkannte Standardmethode zur Kultivierung von Campylobacter spp. aus unterschiedlichen Quellen, jedoch existieren verschiedene kommerzielle selektive Nährmedien, um ein Überwachsen von Proben durch die fäkale Hintergrundflora zu unterdrücken.

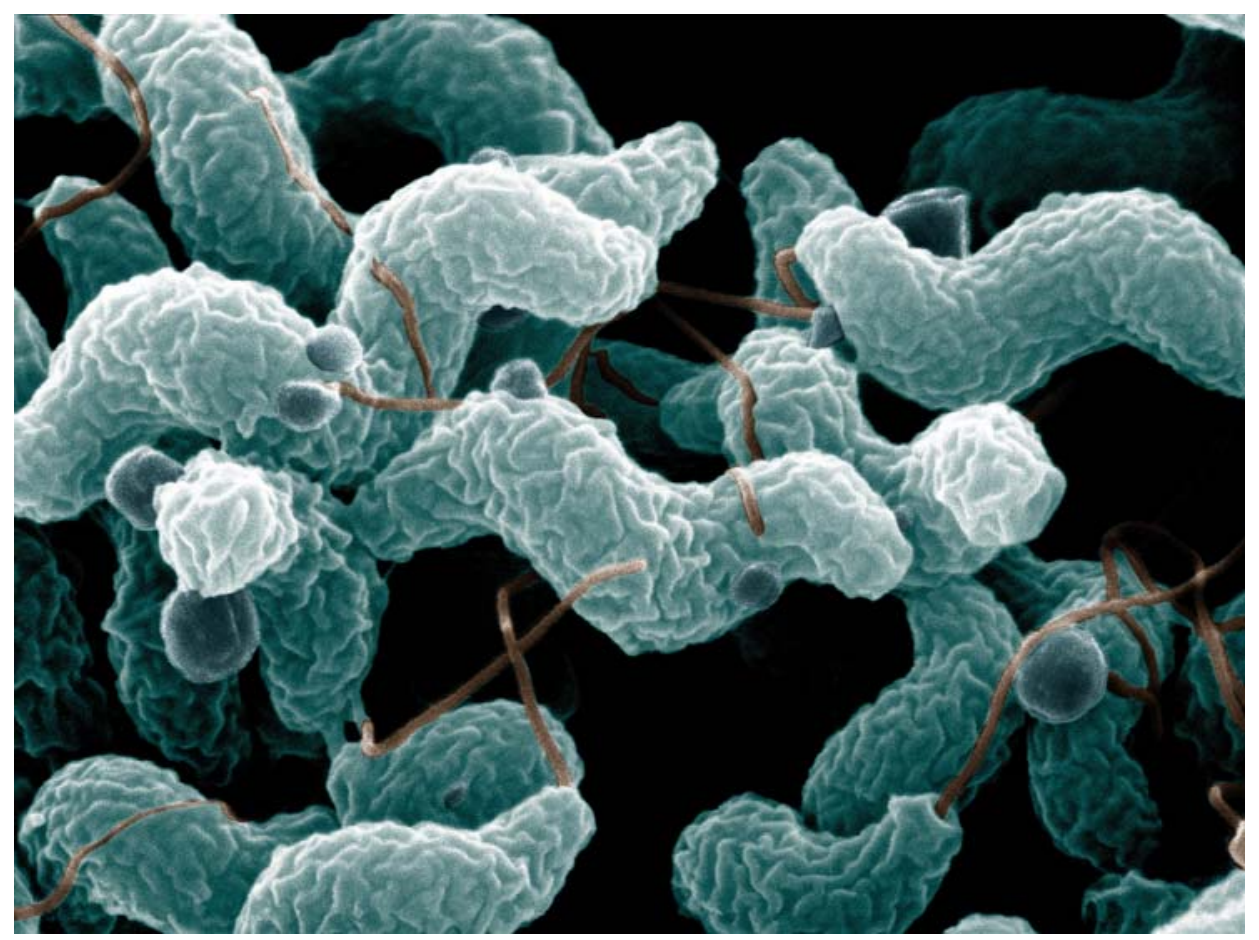

Abbildung 1: Elektronenmikroskopische Darstellung von Campylobacter jejuni (Quelle: http://www.wikipedia.de/Campylobacter/jejuni; 03.01.09) 
Die vermutliche Erstbeschreibung dieses Keimes erfolgte bereits 1886 durch niemand Geringeren als Theodor Escherich, welcher ihn im Colon von Säuglingen nachwies, die an einer, wie er es nannte, „Cholera infantum“ verstorben waren (vermutliche Unterform C. fetus). Eine Kultivierung gelang ihm allerdings noch nicht (Kist 1985). So gerieten diese frühen Erkenntnisse in Vergessenheit und der Keim trat in den nachfolgenden Jahrzehnten zunächst nur bei Rindern und Schafen ins Blickfeld, bei denen er durch Infektion trächtiger Nutztiere zum Abort und damit zu hohen wirtschaftlichen Verlusten führte. Erst 1947 gelang in Frankreich die erste Isolierung von dem nach damaliger Nomenklatur so genannten Vibrio fetus aus dem Blut einer Schwangeren, die einen septischen Abort erlitten hatte (Vinzent et al. 1947). Bis zur generellen Anerkennung der inzwischen neuklassifizierten Campylobacter als fäkale Pathogene und Verursacher von Enteritiden beim Menschen sollte es allerdings noch bis in die späten siebziger Jahre dauern, als verbesserte Isolations- und Kultivierungsverfahren einen sicheren Nachweis zusätzlich zur Mikroskopie erlaubten (Skirrow 1977). Seit dieser Zeit gelang, vor allem durch die Einführung neuer molekulargenetischer Methoden, die Unterscheidung weiterer Spezies neben den bis dato bekannten Campylobacter fetus, Campylobacter coli, Campylobacter sputorum und dem uns im Besonderen interessierenden Campylobacter jejuni. Auch die Entdeckung und Abgrenzung des verwandten, als Verursacher von Magengeschwüren große medizinische Bedeutung besitzenden Helicobacter pylori als eigenes Genus erfolgte erst 1984 und fand ihren Abschluss 1991 mit einer kompletten Revision der Taxonomie und Nomenklatur des Genus Campylobacter und verwandter Bakterien (Vandamme et al. 1991). Im Jahre 2000 erfolgte schließlich die Publikation der kompletten Genomsequenz von Campylobacter jejuni und eröffnete damit das Tor für weitergehende molekulargenetische Untersuchungen (Parkhill et al. 2000).

\subsection{Epidemiologie}

Campylobacter ist derzeit, noch vor Salmonella, der zahlenmäßig bedeutendste bakterielle Enteritiserreger in Deutschland und besitzt daher ebenfalls eine immense volkswirtschaftliche Bedeutung. Die Anzahl der gemeldeten Erkrankungsfälle ist weiterhin ansteigend und betrug im Jahre 200962.789 Fälle im Vergleich zu 31.397 gemeldeten Salmonelleninfektionen (Epidemiol Jahrb 2009). Hierbei handelt es sich meist um sporadische Erkrankungen. Nur etwa 4\% der übermittelten Infektionen stehen in Zusammenhang mit einem bekannten Ausbruchsgeschehen (Epidemiol Bull 36/2007). Über 90\%, nach einigen Studien sogar über 99\% (Allos 2001), der Erkrankungen des Menschen werden durch Campylobacter jejuni verursacht, aber auch Infektionen mit anderen Spezies wie C. coli, C. lari, C. hyointestinalis, 
C. upsaliensis und C. fetus werden gelegentlich beobachtet. Alle Altersklassen sind betroffen, jedoch ergeben sich zwei Erkrankungsgipfel bei Kindern unter 4 Jahren sowie jungen Erwachsenen zwischen 15 und 39 Jahren. Wie auch bei anderen lebensmittelbedingten Durchfallerregern zeigen sich außerdem ausgeprägte Sommergipfel von Infektionen durch Campylobacter spp., was auf eine Abhängigkeit von Temperatur und klimatischen Bedingungen, aber auch auf einen Zusammenhang mit Veränderungen des Freizeitverhaltens (Grillen, Picknicks etc.) schließen lässt. Der kontinuierliche Anstieg der Meldezahlen ist aber sicherlich ebenso auf neue und vermehrt eingesetzte Nachweismethoden, wie den AntigenNachweis im Stuhl mittels ELISA oder EIA, zurückzuführen, mit denen inzwischen der Nachweis auch nicht mehr vitaler Erreger gelingt (Epidemiol Bull 36/2007).

\section{3 Ökologie und Infektionswege}

Zu kommerziellen Zwecken gezüchtetes Geflügel, einschließlich Schlacht- und Legehennen sowie Truthähnen und Enten, ist oft in einem hohen Grade mit Campylobacter spp. kontaminiert, obwohl diese Tiere im Falle einer Infektion ab einem Alter von wenigen Tagen (Welkos 1984) in der Regel keine klinischen Zeichen einer Erkrankung zeigen. In durchschnittlich 40\% der untersuchten einheimischen Masthähnchenbestände können Campylobacter spp. mit einem ebenfalls jahreszeitlich bedingten Kontaminationsgipfel von über $70 \%$ in den Sommermonaten August und September nachgewiesen werden. Im Vereinigten Königreich beträgt dieser Anteil sogar über 80\% (Corry und Atabay 2001). Der Nachweis im Geflügel hängt damit zusammen, dass Campylobacter jejuni, u.a. aufgrund der erhöhten Körpertemperatur, zur natürlichen Darmflora von Vögeln gezählt wird. Die Nachweisraten von Campylobacter spp. in Geflügelfleisch im Rahmen der amtlichen Überwachung betragen immerhin noch regelmäßig über 30\%, was die allgemein anerkannte These von Geflügel als primärer Infektionsquelle unterstützt. Hähnchenfleisch ist hierbei häufiger betroffen als Putenfleisch. Bei über zwei Dritteln der Isolate handelt es sich um Campylobacter jejuni (Epidemiol Bull 36/2007). Zur Aufnahme in den Organismus kommt es durch den Verzehr von unzureichend erhitztem oder rekontaminiertem Geflügelfleisch bei mangelhafter Küchenhygiene, wobei sich in Experimenten eine geringe Infektionsdosis von etwa 500 Keimen als ausreichend erwiesen hat (Black et al. 1988).

Neben Geflügel als Hauptreservoir sollen auch Rind, Schwein, Schaf, Ziege und Meeresfrüchte bei der Übertragung auf den Menschen eine signifikante Rolle spielen (Abb.2). Deren Anteil ist aber vermutlich weitaus geringer, wie eine Untersuchung aus dem Jahr 2006 zeigt, in welcher nur $0,7 \%$ der untersuchten Schweinefleischproben sowie $1,9 \%$ der 
untersuchten Vorzugsmilchproben bzw. 0,98\% der untersuchten „Rohmilch-ab-Hof“-Proben mit Campylobacter spp. kontaminiert waren (Epidemiol Bull 36/2007). Als weitere potenzielle Ansteckungsquellen werden mit Fäkalien aus Tiermastbetrieben kontaminiertes Trink- und Oberflächenwasser sowie Kontakt zu Haus- und Heimtieren vermutet. Im Gegensatz zu anderen Darmpathogenen wie Shigella oder Gardia treten dauerhaft bestehende Infektionsketten zwischen Menschen äußerst selten auf und sind aus epidemiologischer Sicht von nur geringer Relevanz (Friedman et al. 2000).

\section{Geflügelfleisch}

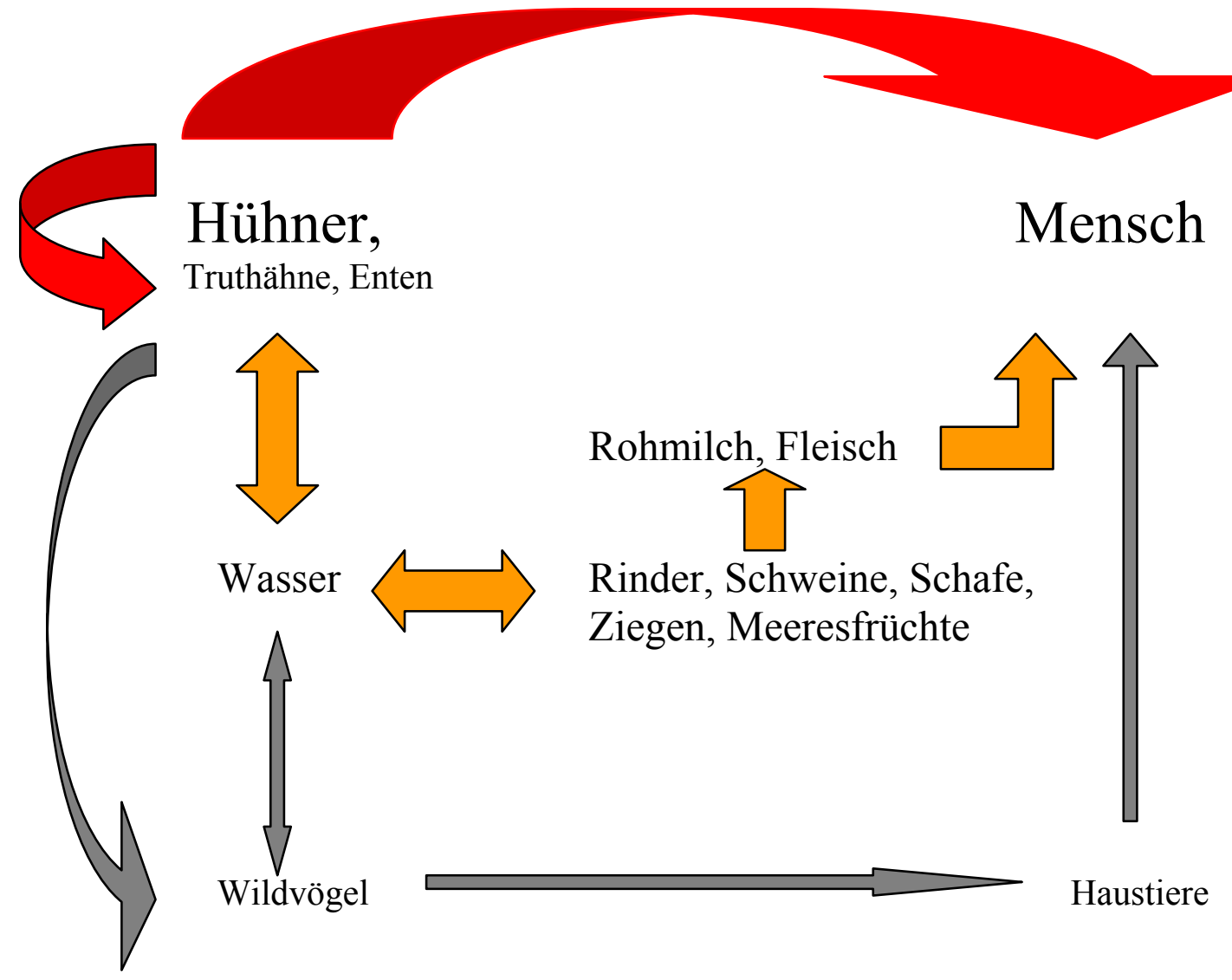

Abbildung 2: Campylobacter jejuni - Transmissionsmodell; adaptiert nach Friedman et al. 2000, S.130

\subsection{Krankheitsverlauf}

Eine Infektion mit Campylobacter spp. kann beim Menschen von einem nahezu asymptomatischen Verlauf bis hin zu einem breiten Spektrum von klinischen Symptomen führen, ist in der Regel aber selbstlimitierend und bedarf nur einer symptomatischen Behandlung. Häufige Beschwerden sind Fieber, abdominelle Krämpfe (oft in die rechte Fossa iliaca ausstrahlend) und Diarrhoe (nicht selten auch blutig oder leukozytär) und dauern von 
wenigen Tagen bis hin zu einer Woche. Eine Campylobacter-Enteritis kann damit die Symptome einer Appendizitis imitieren und Fehldiagnosen führen oftmals zur unnötigen operativen Entfernung des Wurmfortsatzes. Des Weiteren können in seltenen Fällen auch schwerwiegendere Komplikationen wie Persistenz der Diarrhoe, Bakteriämie, Endokarditis, Meningitis oder Harnwegsinfekte auftreten (Blaser 1995). Besonders ältere oder immungeschädigte Patienten (z.B. durch HIV, Diabetes mellitus oder chronischen Alkoholismus) scheinen hier gefährdet (Perlman et al. 1988) und benötigen dann eine antibiotische Therapie. Mittel der Wahl bei systemischen Infektionen sind Erythromycin oder Fluorochinolone (Hof und Dörries 2005). Insbesondere für Campylobacter fetus besteht zudem eine Prädisposition für plazentare und fetale Gewebe nach vermuteter hämatogener Aussaat aus dem Intestinaltrakt. Der Verlauf bei der Mutter ist gewöhnlich milde, doch selbst unter angemessener antimikrobieller Therapie beträgt die durchschnittliche Mortalität bei Feten und Neugeborenen noch über 70\% (Lastovica und Skirrow 2000). Eine typische Spätkomplikation, ähnlich wie bei anderen Durchfallerregern, ist das Auftreten einer reaktiven Arthritis bis zu sechs Wochen nach vorausgegangener Infektion. Der Besitz des HLA-B27-Gewebeantigens ist hierbei stark prädisponierend (Skirrow und Blaser 2000). Auch das Guillain-Barré-Syndrom (GBS), welches durch eine autoimmunologische Demyelinisierung und damit progredient aufsteigende Lähmung peripherer Nerven gekennzeichnet ist und unbehandelt innerhalb weniger Tage bis zur vollständigen Atemlähmung führen kann, ist eindeutig mit einer abgelaufenen Campylobacter-Enteritis assoziiert. Der vermutete Pathomechanismus besteht in einer molekularen Mimikry zwischen bestimmten Lipopolysaccharidstrukturen des Bakteriums und den Gangliosiden der Schwann'schen Zellen der Nervenscheiden. Schätzungsweise einer von 1000 klinisch manifesten Enteritis-Fällen entwickelt 7 bis 21 Tage nach Infektion ein GBS. Jedoch werden nur bestimmte Penner-Serotypen von Campylobacter jejuni (z.B. O19) hierfür verantwortlich gemacht (Nachamkin et al. 2000).

\subsection{Pathogenese und Virulenzfaktoren}

Die Pathogenese der von Campylobacter jejuni verursachten Enteritiden ist noch unzureichend verstanden, zum einen aufgrund des Fehlens eines geeigneten Kleintiermodells für die Infektion, zum anderen aufgrund der Resistenz des Organismus gegenüber genetischer Manipulation (van Vliet und Ketley 2001). Dennoch wurden in den letzten Jahren einige Fortschritte erzielt und mehrere gesicherte und potenzielle Virulenzfaktoren konnten identifiziert werden. Hierzu gehören verschiedene Gene, welche die flagellare Motilität und 
die Fähigkeit des Keimes zur Kolonisation der Mukusbarriere, Adhärenz und Invasion von Enterozyten regulieren (Ketley 1997). Die relativen Adhäsions- und Invasionsraten variieren teilweise sehr deutlich zwischen verschiedenen Isolaten. Von Patienten mit schwerwiegenden Symptomen wie Fieber und Diarrhoe isolierte Stämme zeigen in Zellkulturexperimenten eine höhere Adhärenz als solche von Individuen ohne diese Symptome (Fauchere et al. 1986). Aus der Umwelt isolierte Stämme erweisen sich als deutlich weniger invasiv gegenüber HeLaZellen als klinische Isolate (Newell et al.1985). Der Eintritt in die Zellen erlaubt dem Bakterium sowohl die angeborene Immunantwort des Wirtes mit Komplementaktivierung und Phagozytose als auch die spezifische Antwort in Form von Antikörpern bei zuvor bereits exponierten Individuen zu umgehen (Konkel et al. 2000). Dies geschieht rezeptorvermittelt nach Anlagerung an die Zelloberfläche unter Vermittlung von Mikrotubulus- und (nach anderen Autoren zusätzlich) Aktin-abhängigen Mechanismen (Van Deun et al. 2008, Biswas et al. 2003). Des Weiteren ist der Keim in der Lage, längere Zeit sowohl innerhalb von epithelialen Zellen als auch von Monozyten zu überleben und sich dort sogar zu replizieren (Hickey et al. 2005).

Das vermutete Haupttoxin von Campylobacter jejuni ist das Cytolethal distending toxin (Cdt), welches von Isolaten nahezu jeglicher Herkunft produziert wird (On et al. 2006). Weiterhin berichtet eine Vielzahl von Studien von der Produktion diverser zusätzlicher mutmaßlicher Hämolysine sowie Entero- und Zytotoxine durch Campylobacter spp. in Tiermodell und Zellkulturexperimenten (z.B. On et al. 2006, Coote et al. 2007, Kalischuk et al. 2007). Aufgrund von großen Abweichungen in den verwendeten Stämmen, Zelllinien, Kulturbedingungen und Verfahren, ist ein direkter Vergleich dieser Ergebnisse jedoch schwierig (Pickett 2000). Weder die entsprechenden Gensequenzen der vermuteten choleraartigen oder hitze-labilen Enterotoxine noch die entsprechenden Antikörper gegen diese wurden entdeckt (Olsvik et al. 1984). Des Weiteren konnten weder mit Kulturüberständen noch mit Lysat von Cdt-negativen Mutanten der Referenzstämme Campylobacter jejuni 81176 und 11168 gegenüber HeLa- und $\mathrm{CHO}-Z$ ellen signifikante zytotoxische Effekte nachgewiesen werden (Pickett et al. 1996, Purdy et al. 2000, Jain et al. 2009). Auch in einem Säuglingsmaus-Modell zeigte eine Exposition gegenüber verschiedenen Cdt-negativen Campylobacter-Isolaten keinerlei klinische Symptomatik und allenfalls nur leichte histologische Reizerscheinungen des Colon descendens im Gegensatz zur schweren Inflammation des gesamten Gastrointestinaltraktes in der toxinproduzierenden Vergleichsgruppe (Jain et al. 2008). In einem Frettchen-Tiermodel waren Cdt-Minus- 
Mutanten hingegen jedoch weiterhin in der Lage, Krankheitssymptome hervorzurufen (Scott und Tribble 2000). Auch erscheinen mit großer Regelmäßigkeit immer wieder Berichte über die Isolierung von Cdt-negativen Campylobactern von betroffenen Patienten mit enteritischen Beschwerden (AbuOun et al. 2005, Bang et al. 2001, Jain et al. 2009). Trotzdem wird nach bisherigem Wissensstand nur das Cdt als einziges gesichert wirksames Toxin von Campylobacter jejuni angesehen, obwohl nicht ausgeschlossen werden kann, dass einige Stämme zusätzliche Toxine produzieren (Pickett 2000).

\subsection{Cytolethal distending toxin}

Cdt wird neben Campylobacter jejuni von einer Reihe weiterer gramnegativer Bakterien wie Haemophilus ducreyi, Aggregatibacter (früher Actinobacillus) actinomycetocomitans, Escherichia coli, Salmonella Typhi, Helicobacter spp. und Shigella spp. produziert und soll dort zur Pathogenese und Progredienz von Erkrankungen wie dem Ulcus molle, Parodontose und diversen anderen gastrointestinalen Krankheitsbildern beitragen. Die Gensequenzen dieser Toxine zeigen zwar Homologien, aber auch signifikante Unterschiede zueinander (Pickett et al. 1996), die Schlüsselsequenzen mit funktionellen Bedeutungen scheinen jedoch hochgradig konserviert zu sein ( $\mathrm{Hu} \mathrm{X}$ et al. 2006).

Die Erstbeschreibung von Cdt bei Campylobacter jejuni erfolgte 1988 durch Johnson und Lior. Sie berichteten von Experimenten mit HeLa-, CHO-, Hep-2 und Vero-Zellen, in denen drei bis vier Tage, nachdem diese zuvor mit bakteriellen Kulturüberständen behandelt worden waren, langsame Zellschwellung gefolgt von Chromatinkondensation, nukleärer Fragmentation und schließlich Zelltod eintraten. Wurde das Toxin hingegen konfluenten Zellschichten beigegeben, wurden weder Zelltod noch Kernkondensation beobachtet. Das Toxin erwies sich als hitze-instabil, protease-sensibel und konnte von den verwendeten Stämmen selbst nach multiplen Passagen reproduziert werden (Johnson und Lior 1988).

Die Cdt-Gene scheinen universell im Genom von Campylobacter jejuni, Campylobacter coli und zumindest einigen weiteren Campylobacter spp. repräsentiert zu sein, obwohl die Toxinproduktion beziehungsweise Toxinaktivität, in der Regel bestimmt als höchster Titer eines bakteriellen Lysats, welches Zellschwellungen verursacht, zwischen verschiedenen Spezies aber auch verschiedenen Stämmen großen Unterschieden unterworfen zu sein scheint (Pickett et al. 1996). Auch Stämme von Campylobacter jejuni, welche aus unterschiedlichen geographischen Gebieten und Wirtstieren isoliert worden sind, besitzen in der Regel das Toxin. So fanden sich die Toxingene in einer Untersuchung von Eyigor et al. in sämtlichen 
von 70 untersuchten Isolaten aus Hühnchenkadavern, wobei von diesen immerhin 69 auch ein aktives Toxin produzierten (Eyigor et al. 1999).

Die drei in einem polycistronischen Operon aneinandergrenzend angeordneten Gene (Jeon et al. 2005) $c d t A, c d t B$ und $c d t C$, kodieren für drei Polypeptide mit Molekülmassen von jeweils etwa 26, 30 und $20 \mathrm{kDa}$. Diese bilden einen tripartiten Komplex, für dessen volle zytotoxische Aktivität alle drei Untereinheiten benötigt werden. Untersuchungen des von $c d t A$ genaufwärts liegenden Sequenzbereichs zeigten eine etwa $80 \mathrm{bp}$ große nichtkodierende Region, in der durch DNA-Vergleiche zunächst aber keine bekannten Promotorsequenzen gefunden wurden (Pickett et al. 1996). Im weiteren Verlauf konnte in diesem Bereich jedoch durch Primer Extension Assays eine potentielle Promotorsequenz mit Homologien zur „Konsens-Sequenz“ des $\sigma^{70}$ Promotors von Campylobacter jejuni identifiziert werden (Jeon et al. 2005). Beim $\sigma^{70}$ Promotor handelt es sich um den Hauptfaktor für die Transkription der sogenannten bakteriellen housekeeping-Gene. Er ist essentiell für das Überleben aller bekannten Eubakterien (Wösten et al. 1998).

Der Wirkmechanismus des Cytolethal distending toxins war lange Zeit unbekannt und ist auch heute noch nicht vollständig aufgeklärt. Fest steht, dass proliferierende eukaryontische Zellen in verschiedenen Phasen des Zellzyklus' permanent blockiert werden und in Abhängigkeit von Zelltyp und Zellzyklus in einem Zeitraum von einigen Stunden bis zu wenigen Tagen zu Grunde gehen. Menschliche Fibroblasten, wie z.B. HFF-Zellen, werden sowohl in der $\mathrm{G}_{1}$ - als auch der $\mathrm{G}_{2}$-Phase des Zellzyklus arretiert, während andere Zelltypen, wie z.B. HeLa-Zellen, ausschließlich in der $\mathrm{G}_{2}$-Phase blockiert werden (Thelestam und Frisan 2004, Jain et al. 2009). Der postulierte Aktionsweg des Toxins läuft folgendermaßen ab: Nach Synthese der Untereinheiten und Formation des Cdt-Komplexes im Periplasma der bakteriellen Zelle wird dieser über Vesikel der äußeren bakteriellen Membran, sogenannte OMVs, ins extrazelluläre Medium sekretiert (Lindmark et al. 2009). Dies geschieht wahrscheinlich durch posttranslationale Spaltung von CdtA an seiner N-terminalen Signalsequenz (Ueno et al. 2006). Zuvor scheint ein Großteil des Toxins jedoch an der äußeren Membran assoziiert vorzuliegen, wie Immunfärbungen verschiedener bakterieller Fraktionen zeigen (Hickey et al. 2000). Die katalytische Untereinheit CdtB besitzt funktionelle und strukturelle Homologität mit der mammalischen DNAse I, wohingegen CdtA und $C d t C$ lectinartige Bereiche mit Ähnlichkeit zu den rezeptorbindenden Komponenten des Pflanzengiftes Ricin haben (Nesic et al. 2004). CdtA und CdtC sorgen durch Bindung an die 
zelluläre Oberfläche für den Transport des wirksamen Toxinbestandteiles CdtB in die Zielzelle. Damit gehört Cdt zu den „AB $\mathrm{AB}_{2}$-Toxinen“, wie ebenfalls auch das Cholera-, Pertussis- und Diphtherietoxin. Für Cdt aus E. coli und A. actinomycetocomitans wurden zwei mutmaßliche Wirtszell-Rezeptoren identifiziert. Zusätzlich sollen cholesterolreiche zytoplasmatische membrane lipid rafts am Transport von $C d t B$ in die Zielzelle beteiligt sein (Boesze-Battaglia et al. 2006). Ob diese verschiedenen Mechanismen nebeneinander existieren oder zellspezifisch bzw. Cdt-spezifisch sind, bedarf weiterer Untersuchungen. Während $C d t A$ und $C d t C$ an der Membran verbleiben, wird $C d t B$ wahrscheinlich durch rezeptorvermittelte Endozytose mittels clathrin-coated pits (Cortes-Bratti et al. 2000) in die Zelle aufgenommen und durch den Golgi-Apparat zum endoplasmatischen Retikulum und von dort retrograd zum Nukleus transportiert (Heywood et al. 2005) (Abb.3).

Der Eintritt in den Kern wird durch eine nukleäre Translokations-Signaldomäne (nuclear translocation signaldomain, NTS) vermittelt (Smith und Bayles 2006). Dort verursacht CdtB limitierte Doppelstrangbrüche der DNA, die zur Autophosphorylierung der ataxiatelangiectasia mutated kinase (ATM) führen, welche wiederum Chk2 durch Phosphorylierung aktiviert. Es ist erwähnenswert, dass Cdt unter den bisher entdeckten bakteriellen Toxinen als einziges als DNase agiert (Guerra et al. 2005), auch wenn seine Aktivität nur 0.01\% der bovinen DNase I beträgt (Elwell und Dreyfus 2000).

Aktiviertes Chk2-P phosphoryliert CDC25C, welches hierdurch seine Phosphataseaktivität verliert, und nun nicht mehr den Cyklin B/CDK1-P-Komplex dephosphorylieren kann. Hiermit entsteht ein Block am Kontrollpunkt für die Fortführung des Zellzyklus von der $\mathrm{G}_{2^{-}}$ in die M-Phase (Smith und Bayles 2006).

Auf einem alternativen Weg aktiviert die ATM zusätzlich das p53 (Cortes-Bratti et al. 2001), welches infolgedessen die Produktion des cyklinabhängigen Kinaseinhibitors p21 steigert. Dieser inhibiert die Dephosphorylierung des Cyklin-E/CDK2-Komplexes und blockiert somit das Fortschreiten des Zellzyklus von der $\mathrm{G}_{1^{-}}$in die S-Phase (Smith und Bayles 2006). Es ist außerdem möglich, dass p53 zusätzlich auch an der Regulierung des $\mathrm{G}_{2}$-Kontrollpunktes beteiligt ist (Taylor und Stark 2001). 


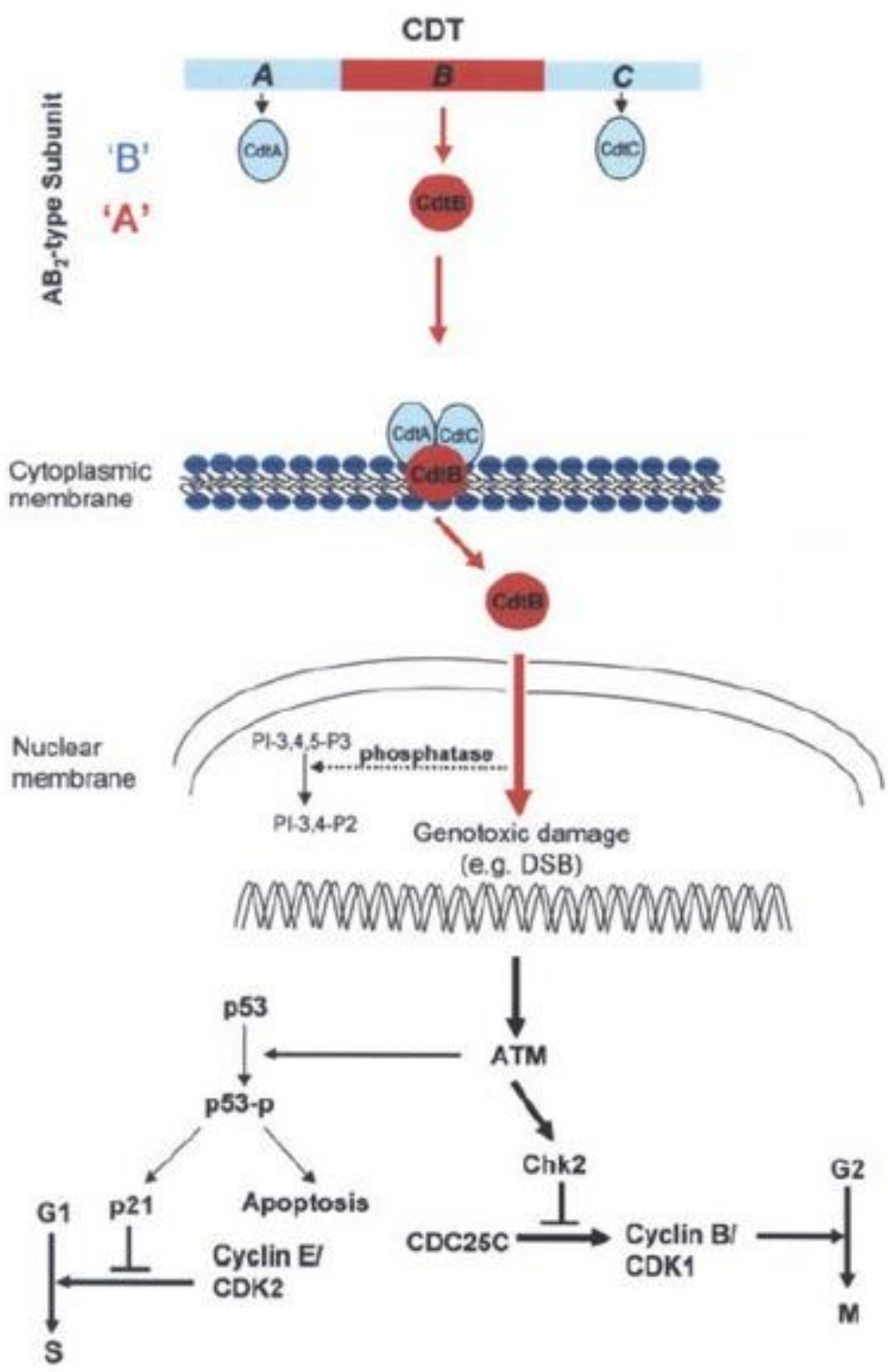

Abbildung 3: Schematische Darstellung von Toxinkomplex, Translokation und zytopathischen Effekten des Cdt (Ge et al. 2008, S. 1600)

Die molekularen Pfade, die zum Cdt-induzierten Zellzyklusarrest führen, sind damit identisch mit den durch ionisierende Strahlung induzierten Kontrollpunktantworten (Cortes-Bratti et al. 2001). Die Position des Blocks ist von der Art der Zielzelle abhängig und führt entweder nur zur Verhinderung des $\mathrm{G}_{2}$-Übergangs (z.B. epitheliale Zellen, Lymphozyten) oder zur Verhinderung sowohl des $\mathrm{G}_{1}$ - als auch des $\mathrm{G}_{2^{-}}$Übergangs (z.B. Fibroblasten). Da die meisten in Untersuchungen des Toxins verwendeten Zelllinien über kein funktionsfähiges p53 verfügen, wurde zunächst ein exklusiver Arrest am $\mathrm{G}_{2}$-Kontrollpunkt angenommen. Neue Studien behaupten weiterhin, dass Cdt auch als Phosphatidylinositol-3,4,5-TriphosphatPhosphatase arbeiten kann, und somit nicht nur seine DNase-Aktivität, sondern auch seine Phosphataseaktivität über diese Signalwege zu einem $\mathrm{G}_{2} / \mathrm{M}$-Arrest in bestimmten Zelllinien führen kann (Shenker et al. 2007). 
Unabhängig davon, welcher Signalweg letztendlich gewählt wird, setzt der irreversible und unphysiologische dauerhafte Zellzyklusarrest an den genannten Kontrollpunkten über Mechanismen, die gegenwärtig noch unzureichend verstanden sind (Whitehouse et al. 1998), in einem zweiten Schritt das Apoptoseprogramm der Zelle in Gang. Dies dauert in Abhängigkeit von Zielzelle und Kinetik des Zellzyklus mehrere Stunden bis Tage, währenddessen die Zelle sich langsam aufzublähen scheint. Lymphozyten erweisen sich in Zellkulturexperimenten empfindlicher gegenüber dem Toxin als epitheliale Zellen und zeigen einen rascheren Übergang von $\mathrm{G}_{2}$-Arrest zur Apoptose ohne Zellschwellung (Hickey et al. 2000, Shenker et al. 2001).

Apoptose ist ein genetisch regulierter, energieabhängiger Prozess, der eine wichtige Rolle bei der Eliminierung überflüssiger Zellen während der Entwicklung und Aufrechterhaltung der Homöostase des Organismus spielt (Ren und Savill 1998). Sie ist charakterisiert durch zelluläre Kondensation, Degradation der Nukleinsäuren und Fragmentation der Zelle in apoptotische Körperchen bei bestehender Membranintegrität. Verschiedene Signalwege, darunter die Aktivierung von sogenannten Todesrezeptoren oder die Permeabilisierung der mitochondrialen Membran mit konsekutiver Freisetzung von pro-apoptotischen Faktoren wie Cytochrom C, können zur Aktivierung der zellulären Caspasekaskade führen. Caspasen sind Cysteinproteasen, die durch proteolytische Spaltung aktiviert werden. Am Ende der Caspasekaskade steht als Effektor die Caspase-3. Diese spaltet sowohl das Inhibitorprotein der Caspase-aktivierten Deoxyribonuclease (CAD) als auch das DNA-Reparaturenzym PARP und leitet somit die oligonukleosomale Degradation der DNA und damit den Zelltod ein. Die Anwendung von Apoptoseinhibitoren hat keinen Einfluss auf die Induktion des Zellzyklusarrestes durch Cdt, verhindert aber das konsekutiv folgende Auftreten von DNAFragmentationen, was darauf schließen lässt, dass diese nicht durch direkte Wirkung des Toxins (DNAse-Aktivität), sondern sekundär durch Aktivierung von endogenen DNAsen im Rahmen der Apoptosekaskade geschehen (Shenker et al. 2006).

Der Beitrag des Toxins zur Pathogenese der durch Campylobacter jejuni verursachten Enteritis scheint somit plausibel, indem es seine Wirkung auf die sich schnell teilenden und differenzierenden Zellen in den Krypten des Darmes ausübt und damit die Entwicklung zu den für die physiologischen absorptiven Vorgänge benötigten reifen Enterozyten unterbricht (Pickett 2000). Frisch kultivierte Zellen, welche vermehrt aktiven Wachstums- und Proteinsynthesevorgängen unterliegen, erscheinen zudem gegenüber den zytotoxischen 
Einflüssen des Toxins empfänglicher als teilungsinaktive semikonfluente Zellschichten (Jain et al. 2009). Eine somit resultierende zeitweilige Disruption und Erosion der normalen, proliferierenden Darmschleimhaut würde konsekutiv zu einer entzündlichen Reaktion führen, welche die von Campylobacter jejuni verursachten blutigen und leukozytären Durchfälle erklärt. Mit der Unterbrechung der Integrität der Darmwand wird ebenfalls einem systemischen Befall Tür und Tor geöffnet. So sind Cdt-Mutanten unbeeinflusst in ihren enterischen Kolonisationsfähigkeiten, zeigen in Tierexperimenten jedoch verringertes Invasionsvermögen in Blut, Milz- und Lebergewebe (AbuOun et al. 2005, Purdy et al. 2000, Van Deun et al. 2008). Auch die, aus Zellkulturexperimenten zu vermutende, apoptotische Wirkung in vivo auf die Effektorzellen der humoralen und zellulären Immunität mit konsekutivem Unterlaufen beziehungsweise Modulation der Immunantwort scheint plausibel, obwohl Campylobacter jejuni in der Regel keine chronifizierenden Infektionen verursacht wie die ebenfalls Cdt-produzierenden A. actinomycetocomitans (Parodontose) und H. ducreyi (Ulcus molle). Eine zeitweilige Unterdrückung und Verlangsamung lokaler Abwehrmechanismen durch Verhinderung der, für eine effektive Immunantwort notwendigen, Fähigkeit von Lymphozyten zur Proliferation lässt sich mit dem in der Regel selbstlimitierenden Charakter einer Campylobacter-Enterits jedoch durchaus in Einklang bringen.

\subsection{Ziele der Arbeit}

Campylobacter jejuni besiedelt den Intestinaltrakt einer Vielzahl von Geflügel- und Säugetierarten. In den meisten Spezies, wie auch dem Huhn als postulierter Hauptinfektionsquelle, tritt kommensale Kolonisation, jedoch keine Inflammation oder blutiger Durchfall wie bei menschlichen Infektionen auf. Dem Cytolethal distending toxin (Cdt) wird ein großer Beitrag zu dieser Pathogenese durch Induktion von Apoptose in exponierten Zellpopulationen zugeschrieben.

Diese Arbeit folgt der generellen Fragestellung, ob es eine Adaptation von Campylobacter jejuni im eigentlichen Wirt bezüglich Apoptose-Induktion durch Cdt gibt, beziehungsweise ob die Herkunft von Campylobacter-Wildtypisolaten (Mensch versus Huhn) oder die Art der befallenen Wirtszelle (humanes Darmepithel versus Hühner-Darmepithel) einen Einfluss auf die bakterielle Toxin-Transkription und die daraus resultierenden zytotoxischen Effekte hat. In diesem Fall könnte dies zur unterschiedlichen Ausprägung der Symptomatik einer Infektion des Intestinaltraktes mit Campylobacter jejuni zwischen Mensch und Huhn 
beitragen. Um dies näher zu untersuchen, sollen menschliche Darmepithelzellen der Zelllinie Caco-2- und primäre Hühnerdarmepithelzellen mit unterschiedlichen CampylobacterWildtypisolaten, gewonnen sowohl aus Hühnerbeständen als auch aus menschlichem Patientengut, infiziert werden. Weiterhin soll die intrazelluläre bakterielle cdt-Transkription mittels RT-PCR verglichen werden. Zusätzlich soll die Apoptose-Induktion in beiden Zellpopulationen unter diesen Bedingungen sowie unter Inkubation mit Lysat der zu untersuchenden bakteriellen Isolate mittels Caspase-3-Test und IFT verglichen werden, um dadurch Rückschlüsse auf die tatsächliche Toxinproduktion und-wirkung zu gewinnen. Durch Analyse und Vergleich dieser Effekte und die zusätzliche Mitführung eines Cdtnegativen Wildtypisolates gelingt es hoffentlich, die beschriebene Fragestellung einer weiteren Klärung zuzuführen. 


\section{Material und Methoden}

\subsection{Material}

\subsubsection{Geräte}

Akku-Pipette

Brutschränke

Fluoreszenzphotometer

Fluoreszenz-/Phasenkontrastmikroskop

Gasbrenner

Geldokumentationsanlage

Gelelektrophoresekammern für Agarose-Gele

Inkubatorboxen

Lightcycler

Magnetrührer

PCR-Thermocycler

$\mathrm{pH}-$ Meter

Photometer

Pipetten

Plattenphotometer

Spannungsgeber für

Gelelektrophoresekammer

Sterilbank

Thermomixer

Ultraschall-Homogenisator

UV-Strahler

Vortexer

Waagen

Wasserbad
Modell pipetus-akku, Hirschmann Laborgeräte, Eberstadt

Modell Cell 240, Heraeus, Hanau

Victor3, Wallac 1420, Perkin-Elmer, Finnland

Axionet 200/Axiostar plus, Zeiss, Jena

FlammyS, SchüttLabortechnik, Göttingen

BioDoc II, Biometra, Göttingen

peqlap Biotechnologie $\mathrm{GmbH}$, Erlangen

Serie Anaerocult, MerckChemicals, USA

Roche, Basel, Schweiz

RCT basic, IKA Labortechnik, Staufen

Modell T3, Biometra, Göttingen

MJ Research PTC100, GMI Inc., USA

Modell 766 Calimatic, Knick, Berlin

Ultrospec 1000, Pharmacia Biotech, Freiburg

Modell Research, Eppendorf, Hamburg

Modell Refecrence, Eppendorf, Hamburg

MRX TC Revelation, Dynex, USA

EPS 500/400, Pharmacia Fine Chemicals, Schweden

BDK-S 1800, BDK Luft- und ReinraumTechnik, Sonnenbühl

Modell Compact, Eppendorf, Hamburg

Modell Sonifier 250, Branson, USA

Modell LK 30, Benda, Wiesloch

Reax Top, Heidolph, Kelheim

CP 2245, Sartorius, Göttingen

GFL, Burgwedel 
Zellkulturmikroskop

Zentrifugen
Modell DM IL, Leica, Heidelberg

Modell 5415 R, Eppendorf, Hamburg

Megafuge 2.0 RS, Heraeus, Hanau

Megafuge 2.0, Heraeus, Hanau

\subsubsection{Verbrauchsmaterialien}

Verbrauchsmaterialien wurden von folgenden Firmen bezogen:

\section{Bakterienkultur/Invasivitätstest:}

Falcon-Tubes, 15ml/50ml (Sarstedt, Nümbrecht); Pasteurkapillaren, 230mm (WG, Mainz); Photometerküvetten, $1.5 \mathrm{ml}$ halbmikro (Brand GmbH, Wertheim); Tupfer (Copan Diagnostics, USA); Impfschlingen, $1 \mu 1 / 10 \mu 1$ (Sarstedt, Nümbrecht)

\section{Caspase-3-Test:}

96-Napf-PS-Microplatten, F-Form (Greiner bio-one GmbH, Frickenhausen)

\section{Doppel-IFT:}

Deckgläser (Menzel Gläser, Braunschweig); Objektträger (Knittel Gläser, Braunschweig)

\section{PCR/RT-PCR:}

LightCycler-Kapillaren (Roche, Schweiz); PCR-Cups (Eppendorf, Wessling-Berzdorf)

\section{Zellkultur:}

Eppendorf-Cups (Eppendorf, Wessling-Berzdorf); Filter tips (Sarstedt, Nümbrecht); 26mm Syringe Filter, $0.20 \mu \mathrm{m}$ Micron Membran (Corning Incorporated, USA); Bottle Top Filter, $0.22 \mu \mathrm{m}$ CA (Corning Incorporated, USA); 6-Napf-/24-Napf-Platten (Greiner bio-one GmbH, Frickenhausen); Neubauer-Zählkammer (Marienfeld, Lauda-Königshofen); Zellkulturflaschen, Serie Cellstar, $25 \mathrm{~cm}^{2} / 75 \mathrm{~cm}^{2} / 175 \mathrm{~cm}^{2}$ (Greiner bio-one $\mathrm{GmbH}$, Frickenhausen)

\subsubsection{Zellkultur, Medien und Zusätze}

\section{Zelllinien}

Caco-2-Zellen

primäre intestinale Hühnerzellen

(primary intestinal chicken cells, PIC)

\section{Medien und Zusätze}

„Dulbecco`s Modified Eagle

Medium“(DMEM)

Natrium-Pyruvat

Natriumhydrogencarbonat $\left(\mathrm{NaHCO}_{3}\right)$

\author{
(ATCC, USA) \\ (I. Hänel, FLI, Jena)
}

mit $580 \mathrm{mg} / 1 \mathrm{~L}-$ Glutamin, $4.5 \mathrm{~g} / 1$

D-Glukose, $3.7 \mathrm{~g} / 1 \mathrm{NaHCO}_{3}$, $8 \mathrm{mg} / \mathrm{l}$ Phenol Rot

$100 \mathrm{mM}$

$7.5 \%$ 
Nicht Essentielle Aminosäuren (NEA)

Penicillin/Streptomycin (Pen-Strep)

Gentamicin

Fötales Kälberserum (FCS)

EDTA (Versen)

Trypsin

PBS (phosphate buffered saline)

Trypsin-EDTA $0.05 \%(1 \mathrm{x})$

Chicken Serum

Insulin (Rind), Pulver

Kollagen Typ II (Huhn)

Minimum Essential Medium (MEM)

Chicken embryonal extract 100fach - Konzentrat

$10.000 \mathrm{U} / \mathrm{ml} ; 10.000 \mu \mathrm{g} / \mathrm{ml}$

$10 \mathrm{mg} / \mathrm{ml}$

inaktiviert durch 45 min Inkubation bei $56^{\circ} \mathrm{C}$

$1 \%$, in PBS ohne $\mathrm{Ca}^{2+}, \mathrm{Mg}^{2+}$

$0.25 \%$, in PBS ohne $\mathrm{Ca}^{2+}, \mathrm{Mg}^{2+}$

(jeweils Biochrom, Berlin)

(GIBCO Cell Culture Products, USA)

$>27$ USP units/mg

mit Earle's Salts und L-Glutamin (jeweils Sigma-Aldrich Germany, München)

(MP Biomedicals, USA)

\subsubsection{Bakterienkultivierung, Medien und Zusätze}

\section{Bakterienstämme}

Campylobacter jejuni jejuni

$\begin{array}{ll}\text { Stamm 81-176 } & \text { (M. Kist, Freiburg) } \\ \text { Stamm av-518 } & \text { (I. Hänel, FLI, Jena) } \\ \text { Stamm av-245 } & \text { (I. Hänel, FLI, Jena) } \\ \text { Stamm B/IV/509 } & \text { (I. Hänel, FLI, Jena) }\end{array}$

Die verwendeten humanen Campylobacter-Isolate entstammen einer institutseigenen Stammsammlung, gewonnen aus einem Patientenkollektiv mit schwerer intestinaler Symptomatik. 
Medien und Zusätze

BBL CampyPak Plus

Brain Heart Infusion (BHI)

Columbia Blut-Agar (5\% Schafsblut)

Einfriermedium:
(Becton Dickinson, USA)

(Bacto, Australien)

(BioMerieux, Nürtingen)

65\% Glycerol

$0.1 \mathrm{M} \mathrm{MgSO}_{4}$

25mM Tris- $\mathrm{HCl}(\mathrm{pH} 8.0)$

\subsubsection{Chemikalien, Enzyme, Puffer}

Ac-DEVD-AMC (5 mg)

Bovines-Serum-Albumin

(Fraktion V, 100g)

HEPES-Pufferlösung (1 M)

Hoechst-Farbstoff 33258

Propansulfonat (CHAPS)

Dimethylsulfoxid (DMSO)

Proteasen-Inhibitor-Cocktail „complete“,
(Bachem, Weil am Rhein)

(Biomol, Hamburg)

(Biochrom, Berlin)

(Invitrogen, Karlsruhe)

(Sigma, Taufkirchen)

(Sigma, Steinheim)

(Roche, Penzberg)

Mini, EDTA-free (PIC)

Die verwendeten Chemikalien und Lösungsmittel wurden, soweit im Text nicht anders gekennzeichnet, von den Firmen Fluka (Seelze), Merck (Darmstadt), Roth (Karlsruhe) und Sigma-Aldrich (Deisenhofen) bezogen. Sämtliche Lösungen wurden mit doppelt destilliertem Wasser angesetzt.

MDB-Puffer:

10 mM HEPES (pH 7.0)

$40 \mathrm{mM} \beta$-Glycerophosphat

$50 \mathrm{mM} \mathrm{NaCl}$

$2 \mathrm{mM} \mathrm{MgCl}_{2}$

5 mM EGTA

Reaktionspuffer für Caspase-3-Test:

MDB-Puffer

$0,1 \mathrm{mg} / \mathrm{ml} \mathrm{BSA}$

$0,1 \%(\mathrm{w} / \mathrm{v})$ CHAPS in MDB

$10 \mu \mathrm{M}$ DEVD-AMC
NP-40 Lyse-Puffer:

$150 \mathrm{mM} \mathrm{NaCl}$

$50 \mathrm{mM}$ TrisHCl

$1 \%$ Triton $\mathrm{X}-100(\mathrm{pH} 8.0)$
TAE-Puffer:

$40 \mathrm{mM}$ Tris

$1 \%$ Essigsäure

1 mM EDTA (pH 8,0) 
TES-Puffer:

$50 \mathrm{mM}$ Tris

5 mM EDTA (pH 8.0)

$50 \mathrm{mM} \mathrm{NaCl}(\mathrm{pH} 8.0)$ 10x Auftragspuffer:

TES-Puffer

$0.07 \%$ Bromphenolblau

$33 \%$ Glycerin

$7 \%$ SDS

\subsubsection{Antikörper}

Maus-IgG1-Anti-Campylobacter jejuni (ATCC 29428)

(BioTrend, Köln)

Cy2-konjugiertes Esel-anti-Maus-IgG F(ab')2-Fragment

(Dianova, Hamburg)

Cy3-konjugiertes Esel-anti-Maus-IgG F(ab')2-Fragment

(Dianova, Hamburg)

\subsubsection{Reaktionssets}

Campylobacter-Spezies-Bestimmung:

API CAMPY Testsystem

(BioMerieux, Frankreich)

\section{Proteinmengenbestimmung:}

BCA Protein Assay Kit

(Pierce,USA)

DNA-Isolierung:

QIAamp DNA Mini Kit

(Qiagen, Hilden)

\section{LightCycler-PCR:}

LightCycler FastStart DNA Master ${ }^{\text {PLUS }}$ SYBR Green I

(Roche, Mannheim)

One-Step-RT-PCR:

QuantiFast SYBR Green RT-PCR Kit (für LightCycler)

(Qiagen, Hilden)

Qiagen OneStep RT-PCR Kit

(Qiagen, Hilden)

\section{RNA-Isolierung:}

RiboPure Bacteria RNA Isolation Kit

(Ambion, USA)

\subsubsection{Oligonukleotide}

Tabelle 1: Verwendete Primernukleotidsequenzen, vollständig bezogen von Sigma (Steinheim).

\begin{tabular}{|c|c|c|c|}
\hline Gen & Sequenz $\left(5^{`}->3{ }^{`}\right)$ & Name & $\begin{array}{c}\text { Produkt- } \\
\text { Länge }\end{array}$ \\
\hline \multirow{2}{*}{ Campylobacter $16 \mathrm{~S}$ ribosomale RNA } & 5`-ATCTAATGGCTTAACCATTAAAC & $\mathrm{F} 2$ & \multirow{2}{*}{$855 \mathrm{bp} *$} \\
\hline & 5 -GGACGGTAACTAGTTTAGTATTCC & CamRev & \\
\hline \multirow{2}{*}{$c d t A$} & 5`-GGAAATTGGATTTGGGGCTATACT & Afw & \multirow{2}{*}{$164 \mathrm{bp} * *$} \\
\hline & 5'-ATCACAAGGATAATGGACAAT & Arev & \\
\hline \multirow{2}{*}{$c d t B$} & 5'-CCAACAGGACGCCATGTGCA & Bfw & \multirow{2}{*}{$200 \mathrm{bp}^{* *}$} \\
\hline & 5'-CTTGAAACTGTAGTAGGTGGAG & Bfev & \\
\hline
\end{tabular}




\begin{tabular}{|l|l|c|c|}
\hline \multirow{2}{*}{$c d t C$} & 5 & Cfw2 & \multirow{2}{*}{$200 \mathrm{bp}^{* *}$} \\
\cline { 2 - 3 } & $5^{\prime}$-TTGCACTCCTACTGGAGATTTG & Crev & \\
\hline
\end{tabular}

*bestimmt nach dem Genom von Campylobacter jejuni jejuni NCTC 11168

**bestimmt nach dem Genom von Campylobacter jejuni jejuni 81-176

verwendete Molekulargewichtsmarker:

100 bp DNA Ladder

(MBI Fermentas, St. Leon-Rot)

\subsection{Methoden}

\subsubsection{Bakterienkultivierung}

\subsubsection{Biochemische Charakterisierung}

Aus einer Kollektion von 24 Campylobacter-Wildtypisolaten, sämtlich isoliert aus einem Patientenkollektiv mit schwerer klinischer Symptomatik, erfolgte eine Vorauswahl nach biochemischer Charakterisierung mittels eines handelsüblichen Spezies-Differenzierungs-Kits (API CAMPY, BioMerieux). Ausgewählt wurden drei Isolate, die sich eindeutig als Campylobacter jejuni subspez. jejuni 1 bestimmen ließen, und im Folgenden mit den Klassifizierungen hu-1, hu-2, hu-4 versehen wurden.

\subsubsection{Medien und Wachstumsbedingungen}

Die verwendeten Bakterienstämme wurden für jeweils 48 Stunden auf Columbia Blut Agar (5\% Schafsblut, BioMerieux) bei $42^{\circ} \mathrm{C}$ unter mikroaerophilen Bedingungen $\left(5 \% \mathrm{O}_{2}, 10 \%\right.$ $\mathrm{CO}_{2}, 85 \% \mathrm{~N}_{2}$ ) kultiviert. Diese Atmosphäre wurde generiert in versiegelten Inkubationsboxen unter Verwendung des BBL CampyPak Plus (Becton Dickinson). Tiefgefroren gelagert wurden die Stämme bei $-80^{\circ} \mathrm{C}$ in einer Mischung aus $70 \%$ BHI (Bacto) und $30 \%$ Einfriermedium.Um für die Zellkulturexperimente jeweils einen möglichst hohen Anteil lebendiger, teilungsfähiger und in einer vergleichbaren Wachstumsphase befindlicher Bakterien zu erhalten, wurden hierbei Kulturen von 24 Stunden Dauer verwendet. 


\subsubsection{Zellkultur}

\subsubsection{Caco-2-Zellen - Medien, Wachstumsbedingungen und Passagierung}

Die Caco-2-Zellen wurden je nach Bedarf in $75-\mathrm{cm}^{2}$ - oder $175-\mathrm{cm}^{2}$-Zellkulturflaschen bei $37^{\circ} \mathrm{C}$ unter $5 \% \mathrm{CO}_{2}$ kultiviert. Verwendet wurde DMEM-Medium mit Zusätzen von 10\% FCS, 1\% Penicillin/Streptomycin und 1\% NEA. Nach jeweils 2 bis 3 Tage wurden die Zellen im Verhältnis 1:2 gesplittet. Hierfür wurde das verbrauchte Medium abgesaugt, der Zellrasen mit EDTA (Versen) gespült und anschließend mit Trypsin (0,25\%) unter leichtem Beklopfen der Flasche abgelöst. Die Zellsuspension wurde in angewärmtem Medium aufgenommen, für 5 Minuten unter $400 \mathrm{~g}$ zentrifugiert, der Überstand abgesaugt und die Zellen nach Auflösung des Sediments in frischem Medium erneut ausgesät. Zur längerfristigen Lagerung in flüssigem Stickstoff wurden Zellen aus einer konfluenten $75-\mathrm{cm}^{2}$-Flasche nach Zentrifugation in einer Mischung aus 40\% Zellmedium, 40 \% FCS und 20\% DMSO in 1,5ml Kryoröhrchen übernommen und tiefgefroren. Nach dem Auftauen eines Röhrchens in einem Wasserbad bei $37^{\circ} \mathrm{C}$ wurden die Zellen in eine $75-\mathrm{cm}^{2}$-Flasche überführt, $60 \mathrm{ml}$ Medium hinzugegeben und das Medium nach Anwachsen der Zellen erneut gewechselt, um die toxischen Effekte des Einfriermediums zu verdünnen.

\subsubsection{Primäre intestinale Hühnerzellen - Medien, Wachstumsbedingungen und Passagierung}

Die primären Hühnerdarmzellen benötigten zusätzlich eine spezielle Kollagenbeschichtung von $6-10 \mu \mathrm{g} / \mathrm{cm}^{2}$ für die verwendeten $25-\mathrm{cm}^{2}-Z e l l k u l t u r f l a s c h e n$. Hierzu wurde eine Stammlösung aus $1 \mathrm{mg} / \mathrm{ml}$ Kollagen in destilliertem Wasser angesetzt, mittels 1M Essigsäure auf einen $\mathrm{pH}-$ Wert von 3 eingestellt und bei $2-8^{\circ} \mathrm{C}$ für mehrere Stunden unter gelegentlichem Schütteln gelagert, bis sich das Kollagen aufgelöst hatte. Nun wurden je nach Bedarf $1 \mathrm{ml}$ Stammlösung mit 8ml destilliertem Wasser, 1ml PBS (10xfach) und $23 \mu \mathrm{l} \mathrm{NaOH} \mathrm{(1M)}$ vermengt und diese Arbeitslösung nach sorgfältiger Durchmischung durch einen $0.2 \mu \mathrm{m}$ Filter sterilfiltriert. Zur Beschichtung der 25- $\mathrm{cm}^{2}$-Zellkulturflaschen wurde je $1 \mathrm{ml}$ Arbeitslösung pro Flasche durch Schwenken sorgfältig verteilt und diese bei $37^{\circ} \mathrm{C}$ für 3 bis 4 Stunden inkubiert. Danach wurde die überstehende Flüssigkeit vorsichtig abgenommen und die Flaschen über Nacht unter UV-Licht getrocknet. Bei $4^{\circ} \mathrm{C}$ konnten die Flaschen dann für einige Wochen gelagert werden. Vor Gebrauch mussten sie noch mit PBS gespült werden. Das für die primären Hühnerdarmzellen verwendete MEM-Medium enthielt zusätzlich 2,2g/1 $\mathrm{NaHCO}_{3}$, $1 \%$ NEA, 5\% FCS, 5\% Chicken Serum, 0.5\% Chicken embryonal extract, 1\% Natrium- 
Pyruvat und $100 \mathrm{IE} / 1$ Insulin (Rind). Diese Zellen wurden ebenfalls bei $37^{\circ} \mathrm{C}$ unter $5 \% \mathrm{CO}_{2}$ inkubiert und etwa zweimal pro Woche nach Erreichen eines konfluenten Zellrasens im Verhältnis 1:3 gesplittet. Hierzu wurden die Zellen nach Abnahme des Mediums mit vorgewärmtem Trypsin-EDTA (0.05\%) abgelöst, für 2 Minuten bei $110 \mathrm{~g}$ zentrifugiert und nach vorsichtigem Auflösen des Sediments in frischem Medium erneut ausgesät. Die verwendeten primären Hühnerdarmzellen befanden sich bei Erhalt in der Regel zwischen der dritten und sechsten Passage. Da die maximale Passagedauer bei diesen Zellen auf etwa 13 Zyklen limitiert ist, mussten die entsprechenden Experimente nach Erreichen der benötigten Zellzahlen zügig durchgeführt werden.

\subsubsection{Bestimmung der bakteriellen Invasionseffizienz}

\subsubsection{Invasivitätstest}

Für den Vergleich der Invasionraten der untersuchten Isolate wurde der Gentamicin Survival Assay, ein wegen seiner Einfachheit häufig verwendetes Instrument für die Messung der Invasion von Bakterien in eukaryontische Zellen, den Bedürfnissen des Versuchansatzes entsprechend adaptiert (Elsinghorst 1994, Hänel et al. 2004).

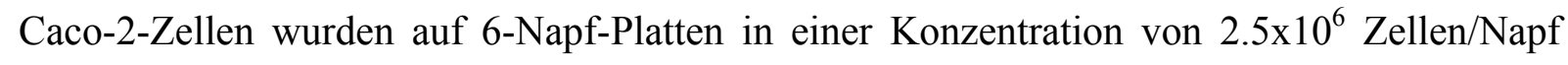
ausgesät und für 24 Stunden bis zum Erreichen einer konfluenten Zellschicht inkubiert. Vor jedem Experiment wurde die aktuelle Zellzahl durch Zählen einer Kontrollprobe bestimmt. Weiterhin wurde der Zellrasen zweimal mit PBS (1x) gewaschen und 2ml MEM-Medium (vergleichbare Bedingungen in Experimenten mit Caco-2 und Hühnerdarmzellen) beigegeben. $\mathrm{Hu}$ und Kopecko (1999) zeigten in Untersuchungen mit INT407 Zellen, dass die Invasionseffizienz von Campylobacter jejuni mit steigender MOI abnimmt, vermutlich aufgrund von Autoagglutination bei höheren Dichten. Die absolute Anzahl internalisierter Bakterien erreicht jedoch ihr Maximum bei einer MOI von $2 \times 10^{2}$ nach einer Inkubationszeit von 2 Stunden. Weiterhin zeigen sich in der mid-log Phase befindliche Bakterien um den Faktor drei bis fünf invasiver gegenüber solchen in der frühen stationären Phase. Aufgrund dieser Untersuchungsergebnisse wurden 24-stündige Bakterienkulturen in 0.9\% NaCl-Lösung überführt und vorsichtig aufgelöst. Bei einer optischen Dichte von 0.5 und einer Wellenlänge von 660nm entspricht dies ungefähr $1.5 \times 10^{9}$ Bakterien/ml (Russel und Blake 1994). Dieser Wert deckte sich gut mit den Ergebnissen aus eigenen Verdünnungsserien zwischen 1x10 ${ }^{9}$ und $2.625 \times 10^{9}$ Bakterien $/ \mathrm{ml}$. In Abhängigkeit von der bestimmten Zellzahl wurden den Näpfen nun die, einer MOI von 300 entsprechenden, erstellten Bakterienlösungen 
hinzugefügt, vorsichtig gemischt und 2 Stunden inkubiert. Nach dreimaligem Waschen mit PBS wurde den Zellen $3 \mathrm{ml}$ Medium mit Gentamicin $(100 \mu \mathrm{g} / \mathrm{ml})$ beigegeben und für weitere 2 Stunden inkubiert, um alle, bis zu diesem Zeitpunkt noch nicht invadierten, extrazellulären Bakterien abzutöten. Danach wurden die Zellen erneut dreimal mit PBS gewaschen, um eventuell verbliebene Reste des Antibiotikums zu entfernen, und anschließend in 1\% Triton X-100 in PBS (Szymanski et al. 1995) für 5 Minuten bei Raumtemperatur lysiert. Das Lysat wurde mehrfach auf- und abpipettiert, um Verklumpungen und Zelldetritus aufzulösen. Nun wurden die freigesetzten Bakterien, einer Verdünnungsreihe in physiologischer Kochsalzlösung folgend, auf Columbia Blut Agar ausplattiert und die Kolonienzahl nach 48 Stunden Inkubation unter den oben genannten Bedingungen ausgezählt. Abschließend konnte die Invasionsrate in Abhängigkeit von der bestimmten Kolonienzahl, der Zellzahl und dem Verdünnungsfaktor berechnet werden.

Die gleiche Versuchsanordnung wurde mit primären Hühnerdarmzellen durchgeführt. Hierfür wurden 500.000 Zellen pro Napf auf zuvor mit Kollagen beschichteten 6-Napfplatten ausgesät und für 48 Stunden bis zum Erreichen einer konfluenten Zellschicht inkubiert. Aufgrund der benötigten großen Zellmenge wurde eine Pool aus mehreren 25- $\mathrm{cm}^{2}$ Zellkulturflaschen verwendet.

\subsubsection{Doppelimmunfluoreszenztest}

Als zweite, direktere Methode zur Bestimmung von Unterschieden im Invasionsvermögen der untersuchten Stämme wurde ein Doppelimmunfluoreszenzverfahren gewählt.

Hierzu wurden wurden je 200.000 Caco-2-Zellen in 24-Napf Platten, in die zuvor 13mm Deckgläser gelegt worden waren, ausgesät und für 24 Stunden bis zum Erreichen der einer konfluenten Zellschicht inkubiert. Nach Medienwechsel (je 0.5ml) wurden die Zellen mit einer MOI von 300 (siehe oben) infiziert, für 2 Stunden inkubiert, dreimal mit PBS gewaschen und für weitere 2 Stunden in Medium (je 1ml), dem 100 $\mu \mathrm{g} / \mathrm{ml}$ Gentamicin beigefügt waren, inkubiert. Danach wurden die Zellen erneut dreimal mit PBS gewaschen, um möglichst viele, außen an der Zellwand verbliebene, abgetötete Bakterien zu entfernen, und für 10 Minuten mit 4\% PFA (in PBS) fixiert. Dieser und alle folgenden Schritte erfolgten bei Raumtemperatur. Nun wurden die unspezifischen Proteinbindungsstellen durch 30-minütige Behandlung mit 1\% BSA (in PBS) gesättigt und nach einem weiteren Waschgang mit PBS der Primärantikörper (Maus-IgG1-Anti-Campylobacter jejuni) in einer Verdünnung von 
1:500 in 1\% BSA (in PBS) hinzugegeben. Nach einer halben Stunde wurde erneut dreimal mit PBS gewaschen, um ungebundene Antikörper $\mathrm{zu}$ entfernen, und dann der erste Zweitantikörper (Cy2-konjugiertes Esel-anti-Maus-IgG) in einer Verdünnung von 1:100 in $1 \%$ BSA (in PBS) beigefügt. Alle folgenden Inkubationsschritte erfolgten unter Ausschluss von Licht. Nach weiteren 30 Minuten wurde erneut dreimal gewaschen und die Zellen nun für eine halbe Stunde mit 1\% Triton X-100 (in 1\% BSA/PBS) behandelt, um die Zellwände für die folgenden Antikörper-behandlungen durchlässig zu machen. Es folgten zwei Waschgänge mit PBS, eine zweite Inkubation mit dem Primärantikörper für 45 Minuten, drei weitere Waschgänge, Inkubation mit dem zweiten Sekundärantikörper (Cy3-konjugiertes Esel-antiMaus-IgG) in einer Verdünnung von 1:400 in 1\% BSA (in PBS) für 45 Minuten und zuletzt wiederum drei Waschgänge. Nun wurden die Zellkerne mit HOECHST-Farbstoff 33258 in einer Konzentration von 50ng/ml (in PBS) für 1 Stunde angefärbt. Abschließend wurde ein letztes Mal mit PBS gewaschen, die Deckgläser mittels Mowiol auf Objektträgern fixiert und über Nacht bei $4^{\circ} \mathrm{C}$ getrocknet.

Die Präparate wurden unter dem Fluoreszenz-/Phasenkontrastmikroskop begutachtet, um die Menge der internalisierten Bakterien und die Zellzahl pro Gesichtsfeld zu bestimmen. Extrazelluläre Bakterien lieferten hierbei nur ein Signal durch den Cy2-Farbstoff, intrazelluläre hingegen zusätzlich durch $\mathrm{Cy} 3$, weshalb zur Bestimmung der Menge der intrazellulären Bakterien letztere Anzahl von ersterer subtrahiert werden musste (vergleiche Byrne et al. 2007). Die Zellzahl ergab sich aus Addition der mittels HOECHST gefärbten Zellkerne.

Wiederum wurde die gleiche Versuchsanordnung auf kollagenbeschichteten Deckgläsern mit primären Hühnerdarmzellen durchgeführt. 50.000 Zellen pro Napf wurden in MEM-Medium ausgesät und 48 Stunden bis zum Erreichen einer konfluenten Zellschicht inkubiert. Als problematisch erwiesen sich die zahlreichen Waschschritte, da die Zellen trotz Kollagenbeschichtung auf der Glasoberfläche der Deckgläser nur schlecht anhafteten und sich der Zellrasen folglich oftmals zusammenzog oder ablöste.

\subsubsection{Herstellung des Campylobacter-jejuni-Lysates}

Kulturen der verwendeten Stämme wurden nach 24-stündiger Inkubation (Columbia Blut Agar, mikroaerophilen Bedingungen, $42^{\circ} \mathrm{C}$ ) abgenommen und in physiologischer Kochsalzlösung aufgelöst. Nach Einstellung einer optischen Dichte von 0.5 bei $660 \mathrm{~nm}$ 
wurden die Bakterien lysiert. Dies erfolgte mit Hilfe des Sonifier 250 UltraschallHomogenisators (Branson, USA) auf Stufe 5 über einen Zeitraum von 10 Minuten. Die Proben wurden hierbei auf Eis gelagert, um eine Inaktivierung des bakteriellen Toxins durch Hitzeentwicklung zu verhindern (Schulze et al. 1998). Die Lysate wurden durch einen $0.22 \mu \mathrm{m}$-Filter sterilfiltriert und für den späteren Gebrauch bei $-80^{\circ} \mathrm{C}$ gelagert (vergleiche Van Deun et al 2007).

Eine Proteinmengenbestimmung wurde durchgeführt, um sowohl die Proben untereinander als auch die im Verlauf der Experimente wiederholt neu hergestellen Lysate vergleichen und auf eine einheitliche Konzentration einstellen zu können. Die photometrische Bestimmung des Proteingehaltes erfolgte mit einem BCA-Proteintest (Pierce, siehe Herstellerangaben) in einer 96-Loch-Platte. Als Standards diente eine BSA-Konzentrationsreihe mit 200, 400, 600, 800, 1000, $1200 \mu \mathrm{g} \mathrm{BSA} / \mathrm{ml}$. Von Standards und Proben wurden je eine Doppelbestimmungen durchgeführt und die Absorption bei einer Wellenlänge $550 \mathrm{~nm}$ gemessen. Für die Auswertung wurde mit den BSA-Standards mit Hilfe von EXCEL eine Eichgerade erstellt. Anhand einer Geradengleichung konnte der Proteingehalt der Campylobacter-Lysate bei bekannter Absorption errechnet werden.

\subsubsection{Apoptoseversuche}

\subsubsection{Infektion mit Campylobacter-jejuni-Isolaten}

Caco-2-Zellen wurden (wie in 2.2.3.1 beschrieben) vorbereitet. Verwendet wurde für beide Zelltypen MEM-Medium, um vergleichbare Bedingungen zu gewährleisten. In Vorversuchen und aus der Literatur (Siegesmund et al. 2004) wurden Messpunkte bestimmt, ab denen Effekte feststellbar waren.

Nach Infektion mit einer MOI von 300 und zweistündiger Invasionszeit wurde dreimal mit PBS gewaschen, 3ml Medium plus Gentamicin $(100 \mu \mathrm{g} / \mathrm{ml})$ hinzugegeben und für weitere 2 Stunden inkubiert (Van Deun et al. 2008). Es folgten drei weitere Waschschritte, um abgetötete Bakterien und Reste des Antibiotikums zu entfernen, und Zugabe von $2 \mathrm{ml}$ antibiotikafreiem Medium. Die Negativkontrollen unterliefen derselben Behandlung. Die Zellen wurden nach 24 und 48 Stunden Inkubation zur Caspase-3-Aktivitätsbestimmung (siehe unten) durch Abtrypsinieren geerntet. Abgestorbene Zellen wurden vorher durch zweimaliges Waschen mit PBS entfernt. Medienwechsel erfolgten alle 24 Stunden unter 
Zugabe von $20 \mu \mathrm{g} / \mathrm{ml}$ Gentamicin, um die ab diesem Zeitpunkt in einigen Proben aus lysierten Zellen freigesetzten und extrazellulär auftretenden Bakterien abzutöten und zu entfernen.

\subsubsection{Inkubation mit Campylobacter-jejuni-Lysat}

Caco-2-Zellen und primären Hühnerdarmzellen wurden (wie in 2.2.3.1 beschrieben) vorbereitet. Verwendet wurde für beide Zelltypen MEM-Medium, um vergleichbare Bedingungen zu gewährleisten. In Vorversuchen wurden Zeitpunkte und Verdünnungsstufen des (in 2.2.4.1 hergestellten) Bakterienlysates bestimmt, ab denen Effekte nachweisbar waren. Nach Wechsel von 2ml frischem MEM-Medium (ohne Antibiotika) wurden je 666 $\mu 1$ Lysat der ausgewählten Stämme (Verdünnung 1:4, entspricht 2.5 $\times 10^{8}$ Bakterien) zugefügt und vermischt. In den Negativkontrollen wurden stattdessen $666 \mu$ physiologische Kochsalzlösung zugesetzt. Die Zellen wurden nach 24 bzw. 48 Stunden Inkubation zur Caspase-3-Aktivitätsbestimmung (siehe unten) durch Abtrypsinieren geerntet. Abgestorbene Zellen wurden vorher durch zweimaliges Waschen mit PBS entfernt.

\subsubsection{Caspase-3-Aktivitätstest}

Der Caspase-3-Aktivitätstest diente zur Bestimmung der Capase-3-Aktivität in den Caco-2und den primären Hühnerdarmzellen in den unter 2.5.1 und 2.5.2 beschriebenen Versuchsansätzen.

Messprinzip: Aktivierte Caspase-3 spaltet von einem spezifischen Substrat mit der Aminosäuresequenz Asp-Glu-Val-Asp (DEVD) fluorogenes 7-Amido-4-Methylcoumarin (AMC) ab. Die Abspaltung des AMC-Moleküls durch die Caspase wird fluoreszenzphotometrisch quantifiziert. Das Fluoreszenzsignal ist proportional zur Anzahl der abgespalteten AMC-Molekülen und somit proportional zur Caspase-3-Aktivität (Fischer et al. 2001).

Nach Abtrypsinierung der Zellen wurden diese bei 400g zentrifugiert, der Überstand verworfen und das Sediment nach Überführung in ein neues Eppendorf-Cup in 1ml PBS (1x) resuspendiert. Die Zellzahl wurde mittels einer Neubauer-Zählkammer bestimmt. Anschließend wurde mit 6000 Umdrehungen pro Minute für 3 Minuten bei $4^{\circ} \mathrm{C}$ zentrifugiert,

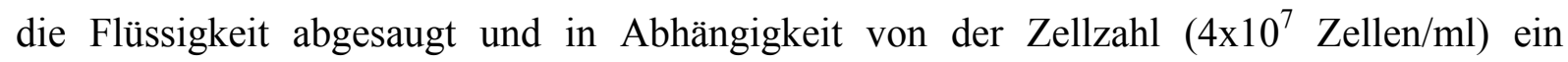
Gemisch aus 25 Teilen NP-40 Lysepuffer auf 1 Teil PIC zugegeben. In den Versuchsansätzen 
mit primären Hühnerdarmzellen wurde aufgrund der geringen Zellzahl die doppelte Menge Lysepuffer/PIC verwendet. Die Proben wurden 15 Minuten auf Eis gelagert und zwischenzeitlich zweimal „gevortext“. Abschließend wurde bei 13.200g zentrifugiert, der Überstand abgenommen und bis zur Messung bei $-80^{\circ} \mathrm{C}$ gelagert.

Triplikate von $10 \mu \mathrm{l}$ des Überstandes wurden in $90 \mu \mathrm{l}$ Reaktionspuffer mit DEVD-AMC aufgenommen. Als Leerwert dienten $10 \mu \mathrm{l}$ destilliertes Wasser mit $90 \mu \mathrm{l}$ Reaktionspuffer. Freies AMC in den Proben wurde in einer 96-Loch-Platte in Abständen von 5 min über 1 Stunde bei $37{ }^{\circ} \mathrm{C}$ (Exzitation: 380/10 nm, Emission: $460 \mathrm{~nm}$, Messzeit pro Probe: 0,5 s) quantifiziert. $\mathrm{Zu}$ den Messzeitpunkten wurde die Fluoreszenz in den Ansätzen als Mittelwert des Triplikates bestimmt. Nach Abzug des Leerwertes wurde die Caspase-3-Aktivität als Steigung im linearen Bereich zwischen 10 und 60 Minuten beziehungsweise als Differenz der beiden Messwerte dargestellt.

\subsubsection{Apoptose- und Mitoseuntersuchungen im Doppelimmunfluoreszenztest}

Caco-2-Zellen und primäre Hühnerdarmzellen wurden (wie in 2.2.3.2 beschrieben) vorbereitet. Verwendet wurde für beide Zelltypen MEM-Medium, um vergleichbare Bedingungen zu gewährleisten. Es wurden je 3 Versuchsansätze für die ausgewählten repräsentativen Stämme hu-3, av-518, 81-176 und die Negativkontrolle durchgeführt:

In Ansatz a) erfolgte nach Medienwechsel $(0.5 \mathrm{ml})$ die Zugabe von $166 \mu$ l Bakterienlysat (Verdünnung 1:4) bzw. physiologischer Kochsalzlösung.

In Ansatz b) wurden die Zellen mit einer MOI von 300 infiziert (und nachfolgend wie in 2.2.3.2 beschrieben behandelt). Nach Abtötung der extrazellularen Bakterien erfolgten drei Waschgänge mit PBS und die Zugabe von Inkubationsmedium plus $20 \mu \mathrm{g} / \mathrm{ml}$ Gentamicin, um die möglicherweise aus lysierten Zellen freigesetzte Campylobacter abzutöten.

In Ansatz c) wurden dem Inkubationsmedium nach Infektion und Abtötung der extrazellulären Bakterien zusätzlich $166 \mu$ Bakterienlysat bzw. $0.9 \% \mathrm{NaCl}$ zugefügt, um eventuelle additive Effekte nachzuweisen.

Nach 24, 48 und 72 Stunden wurde die Inkubation gestoppt und Doppelimmun-fluoreszenz/HOECHST-Färbungen der Präparate hergestellt (siehe 2.2.3.2). Unter dem Fluoreszenz- 
/Phasenkontrastmikroskop wurden Apoptose- und Mitosefiguren ausgezählt. Zusätzlich wurde im Ansatz b) auf Einzelzellebene der apoptotischen bzw. mitotischen Zellen untersucht, ob diese infiziert waren.

\subsubsection{Molekularbiologie}

\subsubsection{Bakterielle cdt-Transkription unter zellfreien Bedingungen}

\section{RNA-Isolierung}

Vierundzwanzigstündige Bakterienkulturen wurden von Columbia Blutagarplatten abgenommen und die bakterielle Gesamt-RNA mit dem RiboPure-Bacteria-Kit (Ambion) entsprechend den Angaben des Herstellers isoliert. Alle folgenden Zentrifugationsschritte erfolgten bei $4^{\circ} \mathrm{C}$ und $13.200 \mathrm{~g}$. Die Proben wurden durch „Vortexen“ in $350 \mu 1$ RNA-Wiz für 15 Sekunden resuspendiert und danach zusammen mit $250 \mu 1$ eisgekühlten Zirconia Beads in $0.5 \mathrm{ml}$ Schraubverschlussröhrchen gegeben. Die Röhrchen wurden manuell kopfüber auf dem Vortexer platziert und für 10 Minuten auf höchster Stufe behandelt, um die bakteriellen Zellwände aufzusplitten. Danach wurde für 5 Minuten zentrifugiert, der Überstand in ein $1.5 \mathrm{ml}$ Tube überführt und mit 0.2 Volumenanteilen Chloroform vermischt. Nach zehnminütiger Inkubation bei Raumtemperatur war es nun möglich, die wässrige und die organische Phase durch fünfminütige Zentrifugation zu trennen. Die obere, wässrige Phase mit der teilweise aufgereinigten RNA wurde in frische Röhrchen überführt und mit 0.5 Volumenanteilen Ethanol (100\%) vermischt. Dieses Gemisch wurde in neue Sammelröhrchen samt Glasfiberfilterpatronen gegeben und erneut für eine Minute zentrifugiert. Im Folgenden wurden den Filterpatronen jeweils einmal $700 \mu \mathrm{l}$ Waschlösung 1 bzw. zweimal $500 \mu 1$ Waschlösung 2/3 zugegeben, für 1 Minute zentrifugiert und der Durchfluss verworfen. Abschließend wurden die Filterpatronen in neue Sammelröhrchen überführt, je zweimal $50 \mu 1$ auf $95^{\circ} \mathrm{C}$ erhitzte Auswaschlösung beigefügt und zentrifugiert, um die RNA auszulösen. Man erhielt auf diese Weise jeweils etwa $90 \mu$ l RNA-Lösung. Die Lösungen wurden abschließend noch einem DNAse-Verdau unterzogen, um eventuell verbliebene DNA-Reste abzubauen. Hierzu wurden pro Probe $10 \mu \mathrm{l}$ DNAse-Puffer mit $4 \mu \mathrm{l}$ DNAse $1(2 \mathrm{U} / \mu \mathrm{l})$ zugegeben und für 30 Minuten bei $37^{\circ} \mathrm{C}$ inkubiert. Die DNAse 1 wurde durch zweiminütige Behandlung mit $20 \mu 1$ Inaktivierungsreagenz ausgeschaltet, welches durch einminütige Zentrifugation und Überführen des Überstandes entfernt werden konnte. Konzentration und Reinheit der RNA wurde bestimmt (siehe unten) und die Proben bei $-80^{\circ} \mathrm{C}$ gelagert. 


\section{Photometrische Bestimmung von Konzentration und Reinheit}

Die Konzentration einer RNA-Lösung lässt sich gemäß dem Lambert-Beer'schen Gesetz photometrisch bestimmt. Die Absorption einer 1:10 Verdünnung wurde bei 260nm mittels

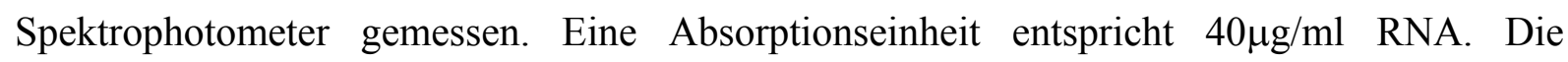
Konzentration ergibt sich aus der optischen Dichte multipliziert mit 40 und dem Faktor der Verdünnung:

RNA-Konzentration $[\mu \mathrm{g} / \mathrm{ml}]=$ OD260 x 40[ $\mu \mathrm{g} / \mathrm{ml}] \times$ Verdünnungsfaktor

Die Reinheit der isolierten RNA wurde mit dem Verhältnis der Absorption bei 260nm zur Absorption bei $280 \mathrm{~nm}$ bestimmt. Dieser Wert sollte zwischen 1.8 und 2.1 liegen, aber auch außerhalb dieses Bereiches sind erfolgreiche weitere Anwendungen gegebenenfalls möglich (siehe Herstellerangaben, RiboPure Bacteria RNA Isolation Kit).

\section{Kontrolle auf potentielle DNA-Kontamination}

Die Proben wurden mittles LightCycler auf kontaminierende Rest-DNA untersucht. Als Negativkontrolle diente $\mathrm{H}_{2} \mathrm{O}$ (PCR-grade), als Positivkontrolle eine Verdünnungsreihe genomischer bakterieller DNA des Stammes 81-176 (isoliert mittels QIAamp DNA Mini Kit, Qiagen, Protokoll siehe Herstellerangabe). Unter Verwendung des FastStart DNA Master ${ }^{\text {PLUS }}$ SYBR Green I - Kits (Roche) wurden jeweils $4 \mu \mathrm{l}$ Enzymmix mit je $0.2 \mu \mathrm{l}$ der Primeroligonukleotide F2 und CamRev (50pmol/ $\mu \mathrm{l}), 5.6 \mu \mathrm{l}_{2} \mathrm{O}$ und $10 \mu \mathrm{l}$ der RNA-Probe gemischt und in Glaskapillaren (Roche) pipettiert. Die Primernukleotide F2 und CamRev umfassen eine für Campylobacter jejuni/coli spezifische Sequenz, die für 16S-rRNA kodiert (Bang et al. 2001, Abu-Halaweh et al. 2005). Der LightCycler wurde nach Zentrifugation der Glaskapillaren (2500rpm, ca. 5 Sekunden) mit diesen bestückt und das Programm 16S (Tab.2) gestartet.

Im Anschluss an die PCR wurden die Reaktionsansätze durch Zentrifugation (2500 rpm, ca. 5 Sekunden) aus den Glaskapillaren befreit. Die Analyse mittels der Gerätesoftware erlaubt bereits eine recht spezifische Untersuchung der entstandenen PCR-Produkte zum Vergleich mit Positiv- und Negativkontrollen. Dennoch wurden die Reaktionsansätze zur Kontrolle auf $1.5 \%$ igem Agarosegel aufgetragen. 
Tabelle 2: PCR-Protokolle: Programm 16S

\begin{tabular}{|c|c|c|c|c|c|c|}
\hline PCR-Schritt & $\begin{array}{c}\text { Segment } \\
\text { Nummer }\end{array}$ & $\begin{array}{c}\text { Zieltemp. } \\
\left({ }^{\circ} \mathbf{C}\right)\end{array}$ & $\begin{array}{c}\text { Zeit } \\
(\mathbf{s e k})\end{array}$ & $\begin{array}{c}\text { Erhitzen/Abkühlen } \\
\left({ }^{\circ} \mathbf{C} / \mathbf{s e k}\right)\end{array}$ & $\begin{array}{c}\text { 2. Zieltemp. } \\
\left({ }^{\circ} \mathbf{C}\right)\end{array}$ & $\begin{array}{c}\text { Schrittgröße } \\
\left({ }^{\circ} \mathbf{C}\right)\end{array}$ \\
\hline Denaturierung & 1 & 95 & 600 & 20 & 0 & 0 \\
\hline \multirow{4}{*}{$\begin{array}{c}\text { Amplifikation } \\
(40 \text { Zyklen) }\end{array}$} & 1 & 95 & 10 & 20 & 0 & 0 \\
\cline { 2 - 7 } & 2 & 55 & 5 & 20 & 50 & $\begin{array}{c}1 \\
\text { (mit 0 Zyklen } \\
\text { Verzögerung })\end{array}$ \\
\hline \multirow{3}{*}{ Schmelzkurve } & 2 & 72 & 20 & 20 & 0 & 0 \\
\cline { 2 - 7 } & 3 & 95 & 0 & 20 & 0 & 0 \\
\hline \multirow{2}{*}{ Kühlung } & 1 & 40 & 15 & 20 & 0 & 0 \\
\hline
\end{tabular}

\section{Agarosegelelektrophorese}

DNA-Fragmente lassen sich ihrer Größe nach auf Agarosegel elektrophoretisch auftrennen (Mülhardt 2002). Das Agarosegel (1.5\%) wurde in 1 x TAE-Puffer in einer Mikrowelle aufgelöst und nach dem Abkühlen auf ca. $60{ }^{\circ} \mathrm{C}$ wurden $0,1 \mu \mathrm{g} / \mathrm{ml}$ Ethidiumbromid zugegeben. Das Gel wurde in eine Flachgelapparatur mit einem Kamm luftblasenfrei gegossen und zum Abkühlen ruhen gelassen. Das erstarrte Gel wurde in einer Gelkammer mit 1 x TAE-Puffer überschichtet und der Kamm entfernt. Die (DNA-)Proben sowie ein DNAMolekulargewichtsstandard (MBI Fermentas) wurden jeweils mit einem 10 x Auftragspuffer versetzt und auf das Gel aufgetragen. Die Elektrophorese erfolgte bei 150V für 30 Minuten. Durch Interkalation des Ethidiumbromids in die DNA konnte diese auf einem Transilluminator mittels Anregung durch UV-Licht sichtbar gemacht und fotografiert werden.

\section{LightCycler One-Step RT-PCR}

Die verwendete Methode zum Vergleich der Toxintranskription bestand aus zwei Abschnitten. Einer quantitativen real-time-PCR für das housekeeping-Gen (Campylobacter jejuni 16S-rRNA) und einer darauffolgenden quantitativen real-time-PCR für die untersuchten Toxingene in den nach 16S-rRNA normierten Proben.

Hierzu mussten die isolierten RNA-Proben jeweils zuerst durch reverse Transkription in einzelsträngige, komplementäre cDNA umgeschrieben werden, bevor mittels LightCycler eine quantitative real-time-PCR durchgeführt werden konnte. Verwendet wurde der QuantiFast SYBR Green RT-PCR Kit (Qiagen). Beide Reaktionen fanden hierbei im selben Ansatz statt (One-Step). Dieses Verfahren wurde trotz erheblich höherer Kosten gewählt, da 
einerseits die Sensitivität höher als im zuvor erprobten Two-Step-Verfahren war und andererseits durch die Reduktion der Arbeitsschritte die Streubreite der erzielten Ergebnisse reduziert wurde.

Zur Normierung auf 16S-rRNA im ersten Arbeitsschritt wurden zu $8.8 \mu$ l der Proben je $10 \mu 1$ Master Mix, $0.5 \mu 1$ Enzym (RT) und je $0.2 \mu 1$ der Primernukleotide F2 und CamRev gegeben. Nach Zentrifugation der Glaskapillaren und Bestückung des LightCyclers wurde das Programm OneStep 16S (Tab.3) gestartet. Mittels Analyseprogramm konnte die Anzahl der Zyklen bis zum Erreichen des Schwellenwertes, der für eine Detektion des PCR-Produktes über den Fluoreszenzhintergrund hinaus notwendig ist, errechnet werden. Diese werden als Crossing Point $(C P)$ einer bestimmen cDNA-Probe bezeichnet - je niedriger der Crossing Point, desto höher der cDNA-Gehalt einer Probe. Unter idealen Reaktionsbedingungen verdoppelt sich die DNA-Menge pro PCR-Zyklus, weshalb aus der Differenz der Crossing Points die relativen Konzentrationsunterschiede der cDNA berechnet werden können:

Faktor des Konzentrationsunterschiedes $=2^{(*)} \Delta(\mathrm{CP})$

*nach empirischen Ergebnissen aus Verdünnungsreihen ist ein Exponent von 1.8 als eher zutreffend anzunehmen

Die Proben wurden entsprechend der errechneten Faktoren verdünnt, um gleiche 16S-rRNAKonzentrationen und damit gleiche Ausgangsmengen an bakteriellem Material zu erhalten. Der Ablauf wurde mehrfach wiederholt, um die Angleichungen zu optimieren und eventuelle Ausreißer zu kompensieren.

Im zweiten Abschnitt folgten die quantitativen real-time-PCR-Untersuchungen der normierten Proben für die Toxingene $c d t A, c d t B$ und $c d t C$. Pipettierschema und Versuchsablauf glichen dem oben beschriebenen Ansatz, verwendet wurden die entsprechenden Primeroligonukleotide Afw, Arev, Bfw, Brev, Cfw und Crev2 und die PCRProgramme OneStep AC beziehungsweise OneStep B (Tab.3). Die Spezifität der Reaktionsprodukte wurde jeweils mittels Agarosegelelektrophorese überprüft. 
Tabelle 3: PCR-Protokolle: Programme OneStep 16S, OneStep AC und OneStep B, Unterschiede zueinander jeweils nur im Amplifikationsschritt

\begin{tabular}{|c|c|c|c|c|c|c|}
\hline PCR-Schritt & $\begin{array}{c}\text { Segment } \\
\text { Nummer }\end{array}$ & $\begin{array}{c}\text { Zieltemp. } \\
\left({ }^{\circ} \mathrm{C}\right)\end{array}$ & $\begin{array}{c}\text { Zeit } \\
(\mathrm{sek})\end{array}$ & $\begin{array}{c}\text { Erhitzen/Abkühlen } \\
\left({ }^{\circ} \mathrm{C} / \mathrm{sek}\right)\end{array}$ & $\begin{array}{c}2 . \text { Zieltemp. } \\
\left({ }^{\circ} \mathrm{C}\right)\end{array}$ & $\begin{array}{c}\text { Schrittgröße } \\
\left({ }^{\circ} \mathrm{C}\right)\end{array}$ \\
\hline
\end{tabular}

\begin{tabular}{|c|c|c|c|c|c|c|}
\hline $\begin{array}{c}\text { Reverse } \\
\text { Transkription }\end{array}$ & 1 & 50 & 3000 & 20 & 0 & 0 \\
\hline \hline Denaturierung & 1 & 95 & 300 & 20 & 0 & 0 \\
\hline
\end{tabular}

Amplifikationsschritt : OneStep 16S
\begin{tabular}{|c|c|c|c|c|c|c|}
\hline \multirow{2}{*}{$\begin{array}{c}\text { Amplifikation: } \\
\text { 16S }\end{array}$} & 1 & 95 & 10 & 20 & 0 & 0 \\
\cline { 2 - 7 }$(40$ Zyklen) & 2 & 55 & 10 & 20 & 0 & 0 \\
\cline { 2 - 7 } & 3 & 72 & 30 & 20 & 0 & 0 \\
\hline
\end{tabular}

Amplifikationsschritt: OneStep AC
\begin{tabular}{|c|c|c|c|c|c|c|}
\hline \multirow{2}{*}{$\begin{array}{c}\text { Amplifikation: } \\
\text { cdtA / cdtC } \\
(45 \text { Zyklen) }\end{array}$} & 1 & 95 & 10 & 20 & 0 & 0 \\
\cline { 2 - 7 } & 3 & 55 & 10 & 20 & 0 & 0 \\
\hline
\end{tabular}

Amplifikationsschritt : OneStep B

Amplifikationsschritt : OneStep B
\begin{tabular}{|c|c|c|c|c|c|c|}
\hline $\begin{array}{c}\text { Amplifikation: } \\
\text { cdtB }\end{array}$ & 1 & 95 & 10 & 20 & 0 & 0 \\
\cline { 2 - 7 }$(50$ Zyklen) & 2 & 65 & 5 & 20 & 61 & $\begin{array}{c}1 \\
\text { (mit 5 Zyklen } \\
\text { Verzögerung) }\end{array}$ \\
\cline { 2 - 7 } & 3 & 72 & 10 & 20 & 0 & 0 \\
\hline
\end{tabular}

\begin{tabular}{|c|c|c|c|c|c|c|}
\hline \multirow{3}{*}{ Schmelzkurve } & 1 & 95 & 0 & 20 & 0 & 0 \\
\cline { 2 - 7 } & 2 & 65 & 15 & 20 & 0 & 0 \\
\cline { 2 - 7 } & 3 & 95 & 0 & 0.2 & 0 & 0 \\
\hline Kühlung & 1 & 40 & 10 & 20 & 0 & 0 \\
\hline
\end{tabular}

\subsubsection{Kinetik der bakteriellen cdt-Transkription nach Infektion}

Caco-2-Zellen wurden nach der in 2.2.3.1 beschriebenen Methode (2.5x106 Zellen, MOI 300) mit Campylobactern des Stammes 81-176 infiziert. Ziel des Experimentes war es herauszufinden, ob sich die Toxintranskription der intrazellulären Bakterien in Abhängigkeit vom Zeitpunkt nach Infektion verändert. Verwendet wurde MEM-Medium. Nach Abtötung der extrazellulären Bakterien und dreimaligem Waschen mit PBS wurde Inkubationsmedium plus Gentamicin $(20 \mu \mathrm{g} / \mathrm{ml})$ zugefügt, um eventuell nachfolgend freigesetzte Bakterien abzutöten. $\mathrm{Zu}$ den Messpunkten (3, 4, 6, 8, 12 und 24 Stunden nach Beginn der Invasion) wurden die infizierten Zellen durch Abschaben geerntet, nachdem sie zuvor dreimal mit PBS 
gewaschen worden waren. Als Vergleichskontrolle diente die zur Infektion der Zellen verwendete Bakterienlösung. Die Proben wurden bei $-80^{\circ} \mathrm{C}$ tiefgefroren und die RNA am nächsten Tag isoliert und auf Rest-DNA untersucht (siehe 2.2.6.1). Der Vergleich der Toxintranskription zu den gewählten Messpunkten erfolgte nach Standardisierung auf 16SrRNA mittels LightCycler One-Step RT-PCR.

Als zweites, semiquantitatives Verfahren kam die photometrische Messung der Bandenstärke auf Agarosegel nach konventioneller One-Step RT-PCR zur Anwendung. Hierbei wurden die RNA-Proben mit dem Qiagen OneStep RT-PCR Kit (siehe Herstellerprotokoll), ähnlich der oben beschriebenen Methode, im Thermocycler (Primernukleotide: F2 und CamRev; Programm: OneStep16S) in cDNA umgeschrieben und mittels PCR amplifiziert. Nach Agarosegelelektrophorese erfolgte die Messung der Bandenstärke des PCR-Produktes mit der Gerätesoftware der Geldokumentationsanlage (BioDoc II, Biometra). Die photometrisch bestimmte Bandenstärke sollte hierbei in proportionaler Beziehung zur Ausgangsmenge an cDNA stehen. Die entsprechenden Verdünnungen der RNA-Lösungen wurden erstellt und der Versuchsablauf mehrfach wiederholt, um möglichst gute Angleichungen zu erhalten. Nun wurden mit den normierten Proben die Messungen für die Toxingene $c d t A, c d t B$ und $c d t C$ (Primernukleotide: Afw, Arev, Bfw, Brev, Cfw, Crev2; Programme: OneStep AC, OneStep B) durchgeführt. Die Spezifität der Reaktionsprodukte wurde jeweils mittels Agarosegelelektrophorese überprüft.

\subsubsection{Bakterielle $c d t$-Transkription nach Infektion verschiedener Wirtszellen}

Caco-2-Zellen und primäre Hühnerdarmzellen wurden (wie in 2.2.3.1 beschrieben) vorbereitet und mit den Campylobacter-Isolaten hu-3, av-518 und 81-176 (je ein Isolat aus Patientengut und Huhn sowie der Referenzstamm) infiziert. Diese Stämme erwiesen sich unter den gewählten Bedingungen als am invasivsten, was den Toxintranskriptionsvergleich (die Cdt-mRNA-Mengen befand sich in den Proben am unteren Ende der Nachweisgrenze) erst ermöglichte. Entsprechend dem Versuchsablauf in 2.2.6.2 wurden die Zellen nach 24 Stunden abgenommen und die Toxintranskription mit dem in 2.2.6.1 beschriebenen Verfahren verglichen. Als Vergleichskontrolle dienten die zur Infektion der Zellen verwendeten Bakterienlösungen. Die Spezifität der Reaktionsprodukte wurde jeweils mittels Agarosegelelektrophorese überprüft. 


\subsubsection{Statistik}

Die statistischen Berechnungen wurden auf einem Personal-Computer durchgeführt. Mittelwerte, Standardabweichungen, Eichgeraden sowie Rechnungen zur Kinetik und Aktivität der Caspase-3 wurden mit EXCEL 2002 angefertigt. Sämtliche Versuche wurden, soweit im Text nicht anders angegeben, mindestens dreimal durchgeführt. Graphiken wurden ebenfalls mit EXCEL erstellt. 


\section{Ergebnisse}

\subsection{Invasivitätsexperimente}

Um beurteilen zu können, ob Unterschiede in Caspase-3-Aktivität und Apoptose-Rate der infizierten Zellen auf unterschiedliche Toxinaktivtäten der untersuchten Bakterienisolate zurückzuführen sind, sollten alle potenziell beeinflussenden Faktoren unter den verschiedenen Proben möglichst vergleichbar sein. Signifikante Differenzen in Invasionsvermögen, intrazellulärem Überleben und intrazellulärer Replikation könnten einen solchen Ansatz schon im Voraus in Frage stellen.

In den im Vorfeld durchgeführten Invasionstests zeigten sich sehr schnell deutliche Unterschiede in der Invasioneffizienz der untersuchten Bakterienisolate (Abb.4). Der vom Huhn isolierte Stamm av-518 erwies sich hierbei unter den gewählten Bedingungen für Caco-2-Zellen als mit Abstand am invasivsten; er erreichte eine Invasionseffizienz von etwa 2,1\%, d.h. 2,1\% der verwendeten Bakterien erreichten eine Internalisierung in die Caco-2Zellen. In einer zweiten Kohorte mit einer etwa zehnfach schwächeren Invasionseffizienz folgten die beiden menschlichen Isolate hu-2, hu-3 und der Referenzstamm 81-176. Nochmals eine etwa zehnfach schwächere Invasionseffizienz zeigten die Stämme hu-1, av-245 und B/IV/509. Die Invasionseffizienz der untersuchten Isolate gegenüber primären Hühnerdarmzellen erschien im Vergleich zu menschlichen Caco-2-Zellen jeweils geringer. Jedoch traten bei diesen Zellen im Verlauf der Versuche Probleme bezüglich Adhärenz an Zellkulturoberflächen und Verklebungen während des Lysevorganges auf, weshalb nur eine geringe Zahl gültiger Experimente durchgeführt werden konnte. Die für die Interaktion der Campylobacter-Stämme mit Hühnerdarmzellen erhaltenen Messwerte sind also unter Vorbehalt zu betrachten und liegen unter in-vivo-Bedingungen wahrscheinlich deutlich höher. Dennoch erwies sich auch für diese Zellen der Stamm av-518 mit einer Invasionseffizienz von etwa $0,72 \%$ deutlich als am invasivsten. Die übrigen Isolate zeigten ebenfalls entsprechend geringere Invasionseffizienzen, die sich jedoch auch mit der für Caco-2-Zellen beobachteten Einteilung in drei Kohorten von unterschiedlichem Invasionsvermögen zur Deckung bringen lassen.

Aufgrund der geschilderten Handhabungsprobleme ist das angewandte Verfahren nicht unkritisch zu sehen. Auch ergaben sich teilweise ausgeprägte Differenzen zu vergleichenden 
Experimenten des FLI Jena (Hänel et al. 2006), welche mit denselben Isolaten unter leicht veränderten Bedinungen (MOI von 100) durchgeführt wurden. Eine Trennung der Isolate in drei Gruppen von deutlich unterschiedlichem Invasionsvermögen lässt sich jedoch nicht von der Hand weisen. Weiterhin scheint die Speziesherkunft der verwendeten Isolate (Mensch versus Huhn) keine Vorhersagen über deren Invasionsvermögen zu erlauben, obwohl das untersuchte Kollektiv naturgemäß zu klein ist, um dies mit Sicherheit behaupten zu können.

\section{Invasionstest}

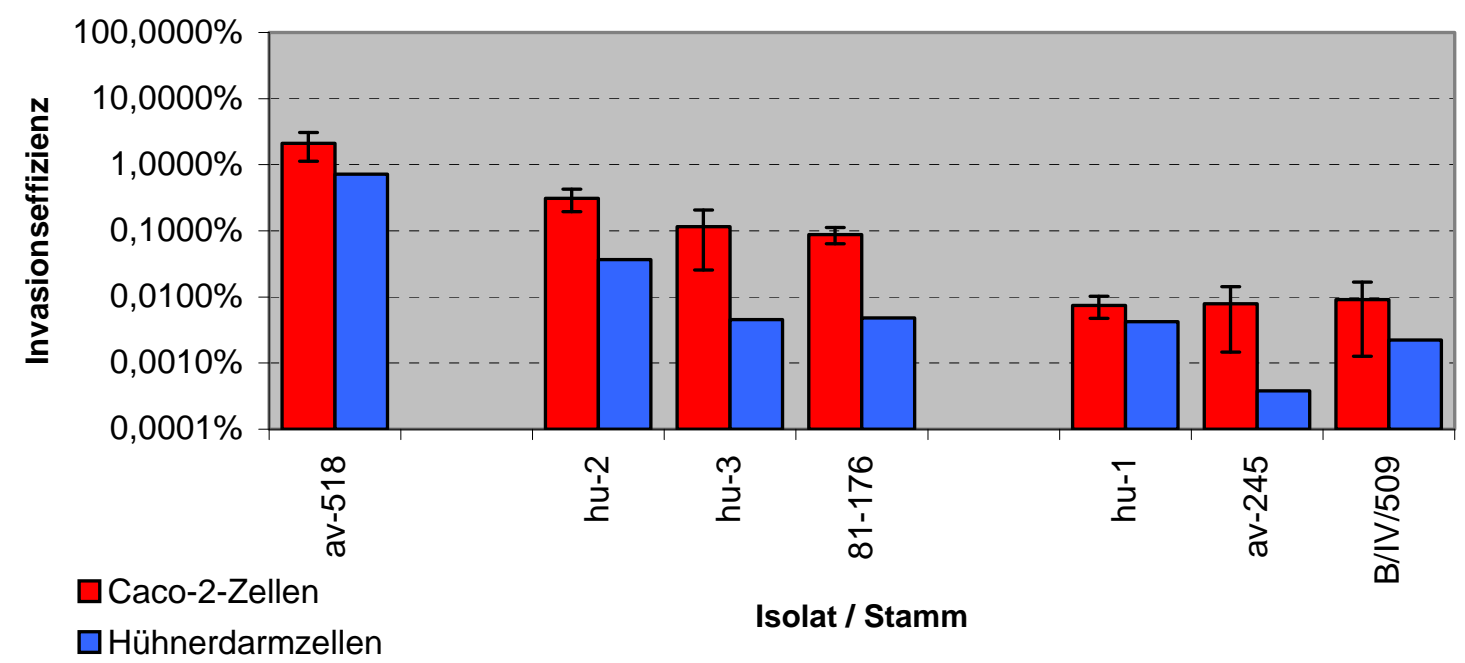

Abbildung 4: Dargestellt sind die Mittelwerte der Invasionseffizienzen der untersuchten Isolate für Caco-2-Zellen (mindestens drei Versuche) und Hühnerdarmzellen (einfache Versuchsdurchführung) bei einer MOI von 300 im Invasionstest. Aufgrund der großen Differenzen wurde eine logarithmische Darstellung gewählt.

Als zweite, direktere Methode wurde daher zur Bestätigung der beschriebenen Ergebnisse ein Immunfluoreszenzverfahren gewählt. Nach Infektion intrazellulär befindliche, durch fluoreszenzfarbstoffgekoppelte Antikörper markierte, Bakterien wurden ausgezählt und die Invasionseffizienz unter Berücksichtigung von MOI und Zellzahl pro Gesichtsfeld berechnet. Auch hier ließ sich die vorherige Einteilung in drei Kohorten mit variablem Invasionsvermögen beibehalten. Die Unterschiede in der Invasionseffizienz zwischen den Isolaten waren jedoch nicht so deutlich ausgeprägt wie im zuvor durchgeführten Invasionstest. Weiterhin ergaben sich nun auch gute Übereinstimmungen mit den Resultaten der Invasionstests des FLI Jena (Hänel et al. 2006), obwohl dort mit einer geringeren MOI von 100 gearbeitet wurde (Tab.4, Abb.5).

Stamm av-518 zeigte mit 2.12\% bzw. $2.47 \%$ erneut die höchsten Invasionseffizienzen für Caco-2- bzw. Hühnerzellen. In einer zweiten Gruppe folgten hu-2, hu-3 und der Referenzstamm 81-176 mit Werten zwischen 0,73\% und 0,44\% (beide Zelltypen). Die 
geringsten Invasionseffizienzen zeigten wiederum hu-1, av-245 und B/IV/509 mit Werten zwischen 0,19\% und 0,06\% (beide Zelltypen).

Tabelle 4: Mittelwerte der Invasionseffizienzen der untersuchten Isolate für Caco-2- und Hühnerdarmzellen (MOI von 300), bestimmt mittels Immunfluoreszenztest. Im Vergleich Ergebnisse des FLI Jena für dieselben Isolate bei leicht veränderten Bedingungen (MOI von 100), bestimmt mittels Invasionstest.

\begin{tabular}{|c|c|c|c|c|}
\hline Stamm I Isolat & $\begin{array}{c}\text { Caco-2 } \\
\text { (IFT) }\end{array}$ & $\begin{array}{c}\text { Caco-2 } \\
\text { (FLI Jena) }\end{array}$ & $\begin{array}{c}\text { Hühnerzellen } \\
\text { (IFT) }\end{array}$ & $\begin{array}{c}\text { Hühnerzellen } \\
\text { (FLI Jena) }\end{array}$ \\
\hline av-518 & $2,12 \%$ & $1,12 \%$ & $2,47 \%$ & $1,53 \%$ \\
\hline hu-2 & $0,73 \%$ & $0,24 \%$ & $0,53 \%$ & $0,85 \%$ \\
\hline hu-3 & $0,64 \%$ & $0,39 \%$ & $0,66 \%$ & $0,76 \%$ \\
\hline $81-176$ & $0,44 \%$ & $0,14 \%$ & $0,52 \%$ & $2,05 \%$ \\
\hline hu-1 & $0,06 \%$ & $0,05 \%$ & $0,09 \%$ & $0,29 \%$ \\
\hline av-245 & $0,17 \%$ & $0,10 \%$ & $0,16 \%$ & keine Angaben \\
\hline B/IV/509 & $0,19 \%$ & $0,13 \%$ & $0,19 \%$ & keine Angaben \\
\hline
\end{tabular}

Weiterhin zeigte sich mit dieser direkten Bestimmungsmethode, dass die untersuchten Isolate gegenüber beiden Zelltypen jeweils vergleichbare Invasionseffizienzen aufweisen. Die limitierten Daten des FLI Jena (Hänel et al. 2007b: nur einfache Versuchsdurchführung) hatten hingegen zunächst ein scheinbar höheres Invasionsvermögen von Campylobacter jejuni gegenüber primären Hühnerdarmzellen im Gegensatz zu Caco-2-Zellen vermuten lassen (Tab.4).

\section{Immunfluoreszenztest}

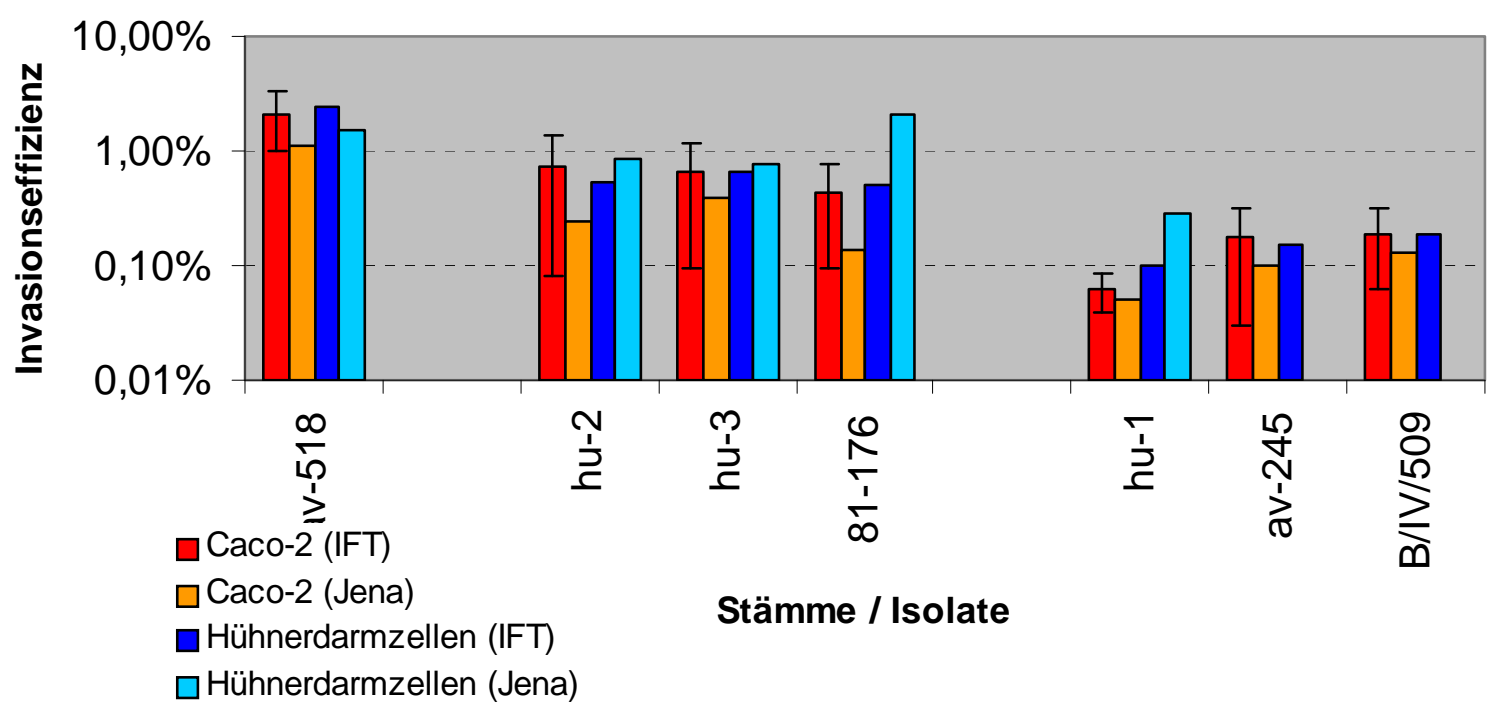

Abbildung 5: Dargestellt sind die Mittelwerte der Invasionseffizienzen der untersuchten Isolate für Caco-2- und Hühnerdarmzellen (MOI von 300), bestimmt mittels Immunfluoreszenztest (IFT). Im Vergleich Ergebnisse des FLI Jena für dieselben Isolate bei leicht veränderten Bedingungen (MOI von 100), bestimmt mittels Invasionstest (limitierte Daten, einfache Versuchsdurchführung, Standardabweichungen nicht bekannt). 
Die interindividuellen Unterschiede in der Invasionseffizienz der Isolate zueinander waren signifikant und betrugen zwischen den Extremwerten teilweise mehr als Faktor 20. Es ergab sich auch mit dieser Methode kein Zusammenhang zwischen Herkunft des Bakteriums und dessen Invasionseffizienz.

Zusammenfassend lässt sich festhalten, dass bei den untersuchten Campylobacter-Isolaten keine Assoziation zwischen ihrer Herkunft (Mensch versus Huhn) und ihrer Invasionseffizienz nachgewiesen werden konnte. Unabhängig von ihrer Herkunft wiesen die Isolate signifikante Unterschiede hinsichtlich ihres Invasionsvermögens auf, was die Vergleichbarkeit von Messergebnissen ihrer intrazellulären Wirkung auf Zellen nach Invasion deutlich erschwert. Weiterführende Experimente zur Bestimmung von intrazellulärem Überleben und Replikation wurden daher für nicht mehr sinnvoll erachtet. Die aus Hühnern isolierten Stämme zeigen jedoch für mindestens $48 \mathrm{~h}$ nach Infektion noch ein intrazelluläres Überleben (Hänel et al. 2007a). Mittels Immunfluoreszenz konnten sämtliche verwendete Isolate ebenfalls noch mindestens $72 \mathrm{~h}$ nach Infektion intrazellulär nachgewiesen werden.

\subsection{Caspase-3-Aktivitäten nach Infektion}

Wie bereits beschrieben, führt das Cytolethal distending toxin (Cdt) über Unterbrechung des Zellzyklus letztendlich zur Aktivierung des Apoptoseprogramms der Zelle mit konsekutiver Initiierung der Caspasekaskade, an deren Ende als Effektor die Caspase-3 steht. Die Messung der Caspase-3-Aktivität erlaubt damit indirekt Rückschlüsse auf die Wirkung des aus intrazellulären Bakterien freigesetzten Cdts, vorausgesetzt der Einfluß von extrazellulärem Toxin ist vernachlässigbar. Aus diesem Grund erfolgten nach Abtötung der extrazellulären Bakterien regelmäßige Waschschritte und Medienwechsel unter Zugabe von $20 \mu \mathrm{g} / \mathrm{ml}$ Gentamicin, um eventuell aus lysierten Zellen freigesetzte Bakterien abzutöten und das Toxin $\mathrm{zu}$ entfernen. Ein weiterer, direkter zu beobachtender, Parameter der Toxinwirkung ist die Entwicklung der Gesamtzellzahl in infizierten Zellkulturproben. Blockierung des Zellzyklus und Initiierung des Apoptoseprogramms sollte sich im Falle infizierter Zellen in einer Verringerung der relativen Zellzahl gegenüber der nicht-infizierten Negativkontrolle niederschlagen.

In Vorversuchen mit Caco-2-Zellen ließen sich $24 \mathrm{~h}$ bzw. $48 \mathrm{~h}$ nach Infektion deutliche Unterschiede in der Caspase-3-Aktivität gegenüber einer nicht-infizierten Negativkontrolle nachweisen, weshalb diese beiden Messpunkte für die nachfolgenden Versuche gewählt 
wurden. Zu späteren Zeitpunkten war der Zellrasen in einigen infizierten Proben bereits zu großen Teilen lysiert.

Die zu beiden Messpunkten bestimmten relativen Zellzahlen der infizierten Proben zeigten eine inverse Korrelation $\mathrm{zu}$ den unter 3.1 ermittelten Invasionseffizienzen der untersuchten Bakterienisolate, ein Effekt der besonders zum zweiten Messpunkt nach 48h deutlich wird (Abb.6). So ergaben die mit dem hochgradig invasiven Stamm av-518 infizierten Proben jeweils die geringsten relativen Zellzahlen. Es folgten wiederum in einer zweiten Kohorte hu-2, hu-3 und der Referenzstamm 81-176. Für die nur geringgradig invasiven Isolate hu-1 und av-245 war der beobachtete Effekt am schwächsten. Stamm B/IV/509 hingegen, welcher zwar eine geringe Invasionseffizienz aufweist, gleichzeitig aber auch als nicht Cdtproduzierend beschrieben wurde (Hänel et al. 2007a), zeigte im Vergleich mit der nichtinfizierten Negativkontrolle keine signifikanten Änderungen der relativen Zellzahlen.

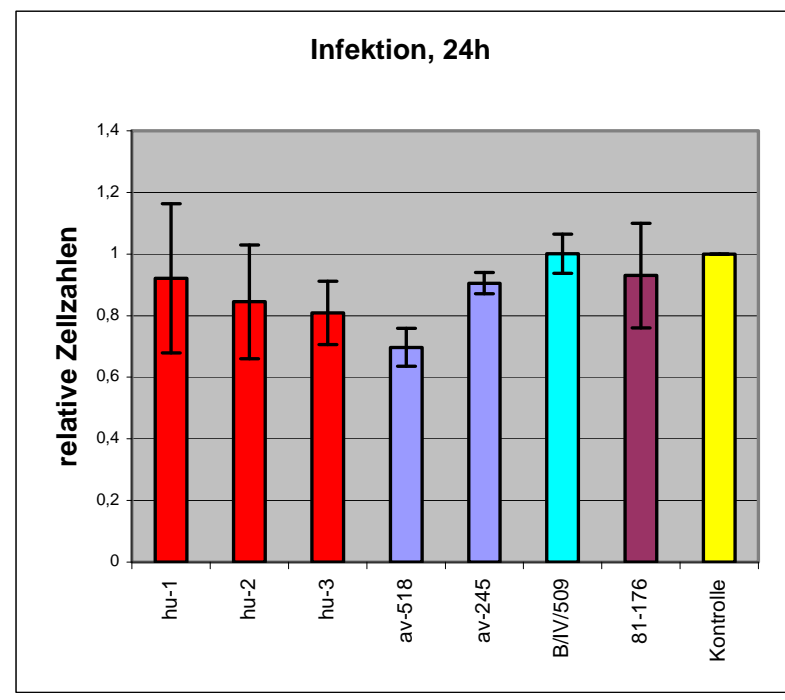

a)

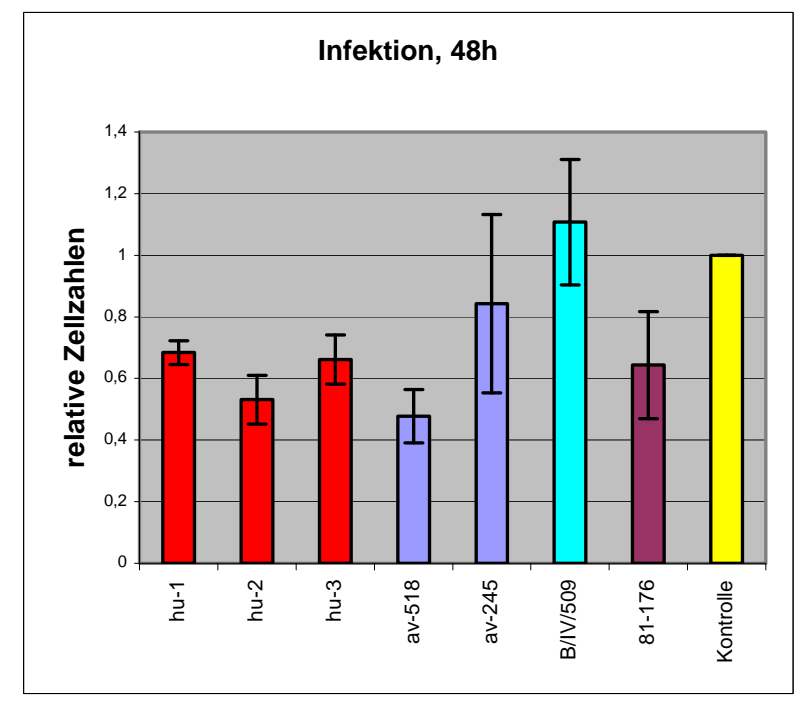

b)

Abbildung 6: Relative Caco-2-Zellzahlen der infizierten Proben im Vergleich zur nicht-infizierten Negativkontrolle, Mittelwerte aus mindestens 3 Versuchen, humane Isolate = rot, aviäre Isolate = blau bzw. türkis, Negativkontrolle = gelb; a) $24 \mathrm{~h}$ nach Infektion b) $48 \mathrm{~h}$ nach Infektion

Auch die relativen Caspase-3-Aktivitäten lassen sich mit den Resultaten der Invasivitätsexperimente zur Deckung bringen (Abb.7). Die untersuchten Isolate induzierten in den infizierten Proben mit abnehmendem Invasionsvermögen gegenüber Caco-2-Zellen (siehe oben) konsekutiv geringere relative Caspase-3-Aktivität im Vergleich zur nicht-infizierten Negativkontrolle. Dieser Effekt wird ebenfalls zum zweiten Messpunkt 48h nach Infektion zunehmend deutlicher. 
Die gemessenen Veränderungen sind dennoch nicht so stark ausgeprägt, wie es aufgrund der ausgeprägten Differenzen in der Invasionseffizienz zu erwarten gewesen wären. So zeigten die mit Stamm av-518 infizierten Zellen nur eine etwa zweieinhalbfach erhöhte relative Caspase-3-Aktivität im Vergleich zur nicht-infizierten Negativkontrolle. In den mit dem Cdtnegativen Stamm B/IV/509 infizierten Proben ergab sich sogar eine geringfügig, jedoch nicht signifikant, verringerte Caspase-3-Aktivität gegenüber der nicht-infizierten Negativkontrolle. Anzumerken bleibt weiterhin, dass das Ausmaß der Differenzen in den Caspase-3-Aktivitäten nicht die teilweise sehr deutlich ausgeprägten Unterschiede in der Invasionseffizienz der Isolate widerspiegelt. Allerdings wurden auch in den folgenden (siehe Versuch 3.3) Inkubationsversuchen mit bakteriellem Lysat nur maximal dreifach erhöhte relative Caspase3-Aktivitäten im Vergleich zur unbehandelten Negativkontrolle beobachtet.

Aufgrund der nur in begrenzter Menge verfügbaren Hühnerzellen wurden die entsprechenden Versuche mit diesen nur einmalig durchgeführt (Daten nicht gezeigt). Ein Zusammenhang von Invasionseffizienz und Caspase-3-Aktivität konnte für Caco-2-Zellen zuvor jedoch hinlänglich nachgewiesen werden. Ein direkter Vergleich der zu untersuchenden Bakterienisolate bezüglich Toxinproduktion und daraus resultierender Apoptose-Induktion scheint mit dieser Methode durch die variierenden Invasionseffizienzen allerdings deutlich erschwert, wenn nicht unmöglich. Weiterhin zeigte eine Infektion mit dem Cdt-negativen Stamm B/IV/509 im Vergleich zu den übrigen Isolaten keinerlei signifikanten Effekt auf die Caspase3-Aktivität, was einen alleinigen Einfluss des Cdt auf die Apoptose-Induktion vermuten lässt.

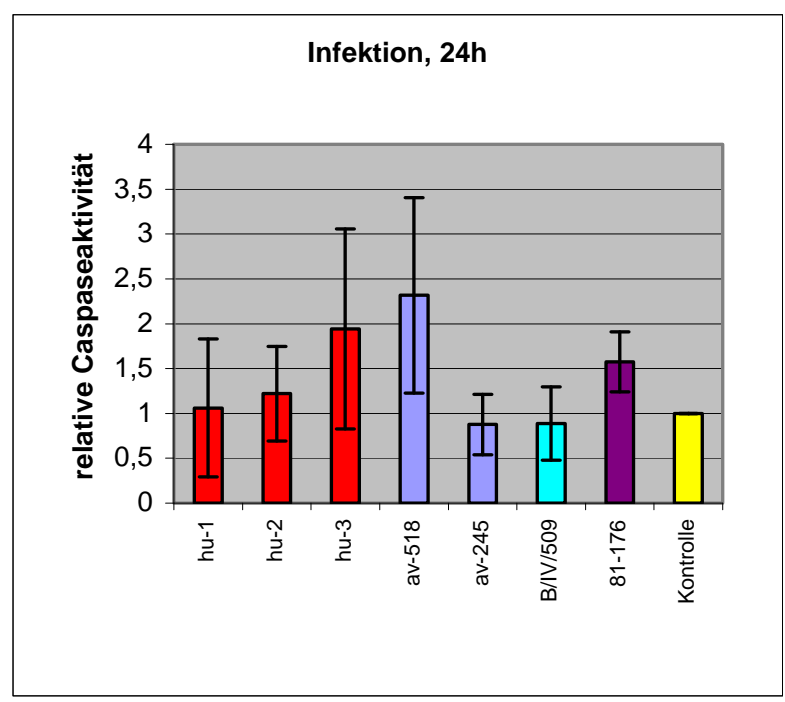

a)

Abbildung 7: Relative Caspase-3-Aktivtäten der infizierten Caco-2-Zellen im Vergleich zur nicht-infizierten Negativkontrolle, Mittelwerte aus mindestens drei Versuchen, humane Isolate $=$ rot, aviäre Isolate $=$ blau bzw. türkis, Negativkontrolle $=$ gelb; a) $24 \mathrm{~h}$ nach Infektion b) $48 \mathrm{~h}$ nach Infektion

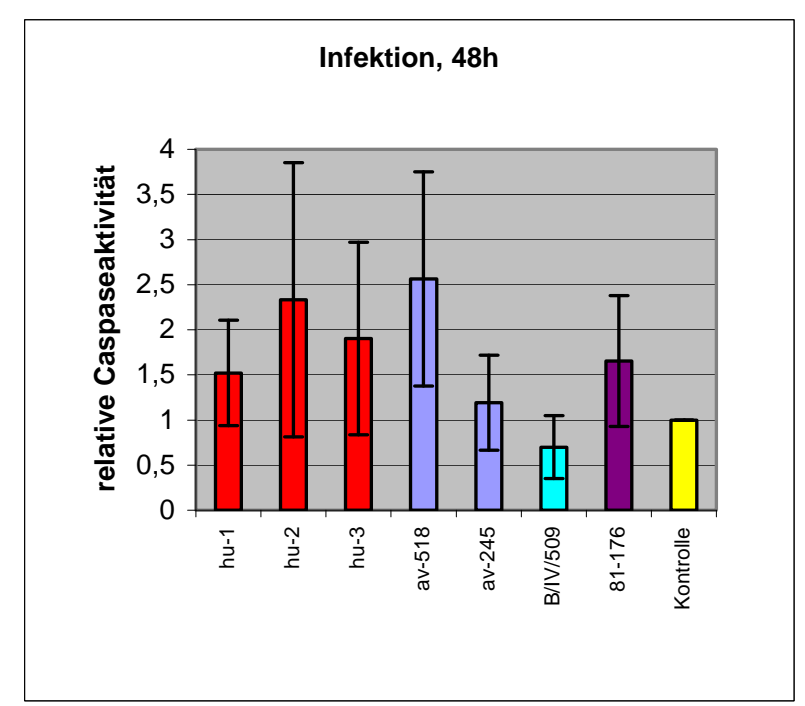

b) 


\subsection{Caspase-3-Aktivitäten nach Inkubation mit bakteriellem Lysat}

Da durch die unterschiedlichen in-vivo-Charakteristika der bakteriellen Isolate bezüglich Invasionseffizienz und intrazellulären Verhaltens ausgeglichene Voraussetzungen für den Vergleich der toxinbedingten Apoptose-Induktion nicht gewährleistet werden können, wurde die Toxinwirkung nach Freisetzung aus äquivalenten Mengen abgetöteter Bakterien untersucht. Hierzu wurden diese nach photometrischer Mengenbestimmung mittels Ultraschall aufgespalten und das Lysat zusammen mit Caco-2-Zellen beziehungsweise primären Hühnerdarmzellen inkubiert. Cdt übersteht diesen Freisetzungsvorgang unbeschadet und gelangt durch den in der Einleitung beschriebenen Aufnahmemechanismus in den Intrazellulärraum, wo es seine Wirkung entfaltet. Verwendet wurde Lysat der humanen Stämme hu-1 und hu-3, sowie der aviären Stämme av-518, av-245 und des Cdt-negativen Stammes B/IV/509. Die Auswahl erfolgte, da diese Stämme in den vorangegangenen Experimenten die stärksten Unterschiede bezüglich Invasionseffizienz und Caspase-3Induktion gezeigt hatten. Die bakteriellen Proteinkonzentrationen im Medium betrugen 58,82 $(+/-10,30) \mu \mathrm{g} / \mathrm{ml}$.

Für die primären Hühnerdarmzellen zeigten sich nach 24-stündiger Inkubation keine signifikanten Unterschiede bezüglich der relativen Zellzahlen, weder zwischen Lysaten von humanen und aviären, noch geringgradig und hochgradig invasiven Stämmen (Abb.8). Nach 48h lieferte Stamm hu-3 jedoch eine leichtgradig stärkere Reduktion der relativen Zellzahlen gegenüber den übrigen Isolaten. Inkubation mit Lysat des Stammes B/IV/509 führte hingegen $\mathrm{zu}$ keiner Verringerung der relativen Zellzahl im Vergleich zur unbehandelten Negativkontrolle. Die Messung der relativen Caspase-3-Aktivitäten ergab nach 24h ebenfalls vergleichbare Werte zwischen den einzelnen Isolaten. Der Effekt war auch hier mit einer zwei- bis zweieinhalbfach erhöhten Aktivität gegenüber der unbehandelten Negativkontrolle (vergleiche 3.2) nicht übermäßig deutlich ausgeprägt. Nach 48h zeigten alle Proben erneut leicht gestiegene Caspase-3-Aktivitäten gegenüber dem vorherigen Messwert. Auch hier zeigte eine Inkubation mit Lysat des Stammes hu-3 mit einer 3,1-fach erhöhten relativen Caspase-3-Aktivität wiederum den stärksten Effekt (jedoch ohne signifikant gegenüber den übrigen Isolaten zu sein). Die mit Lysat des Cdt-negativen Stammes B/IV/509 inkubierten Proben zeigten zu beiden Messpunkten interessanterweise sogar eine zwar geringgradig, jedoch signifikant, erniedrigte Caspase-3-Aktivität gegenüber der unbehandelten Negativkontrolle. 


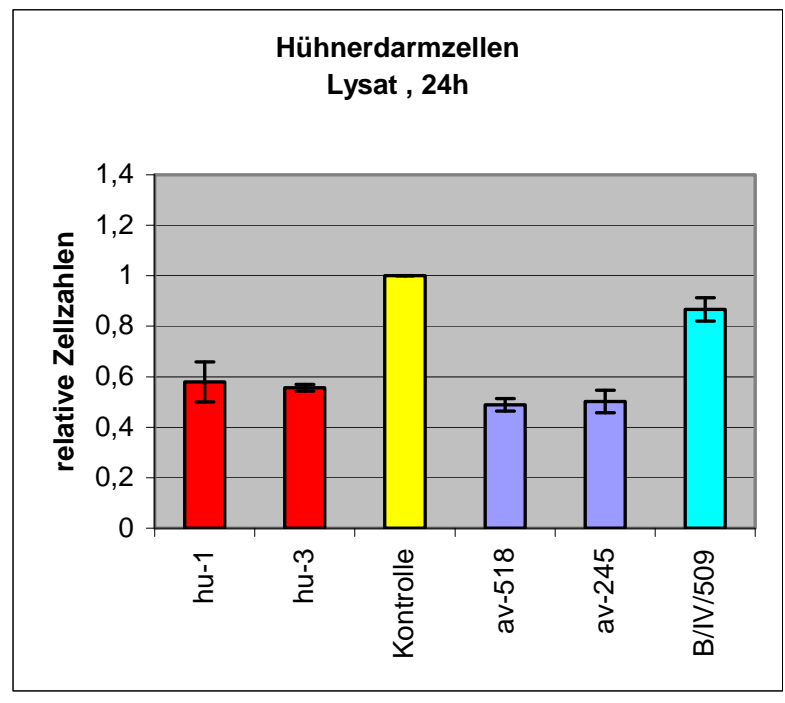

a)

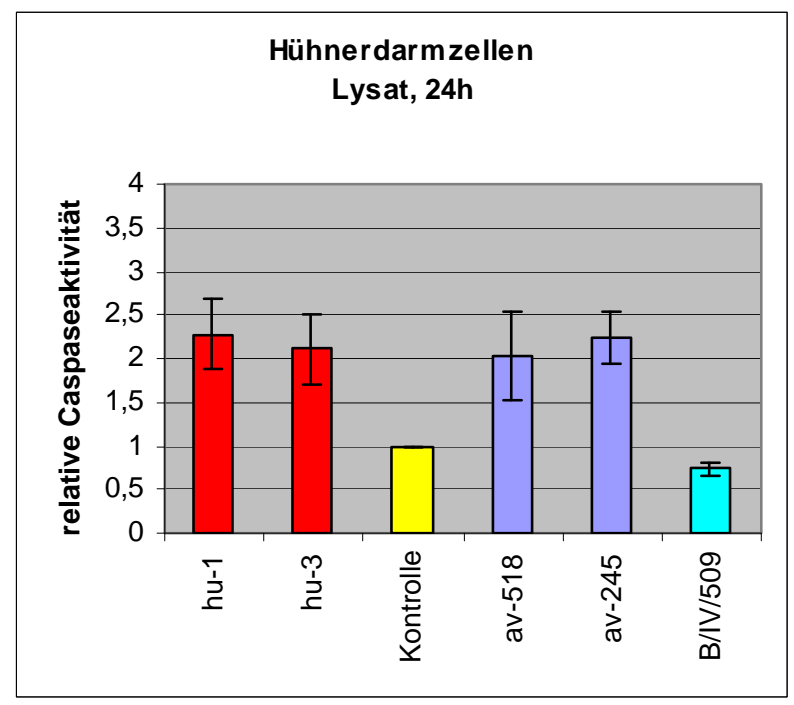

c)

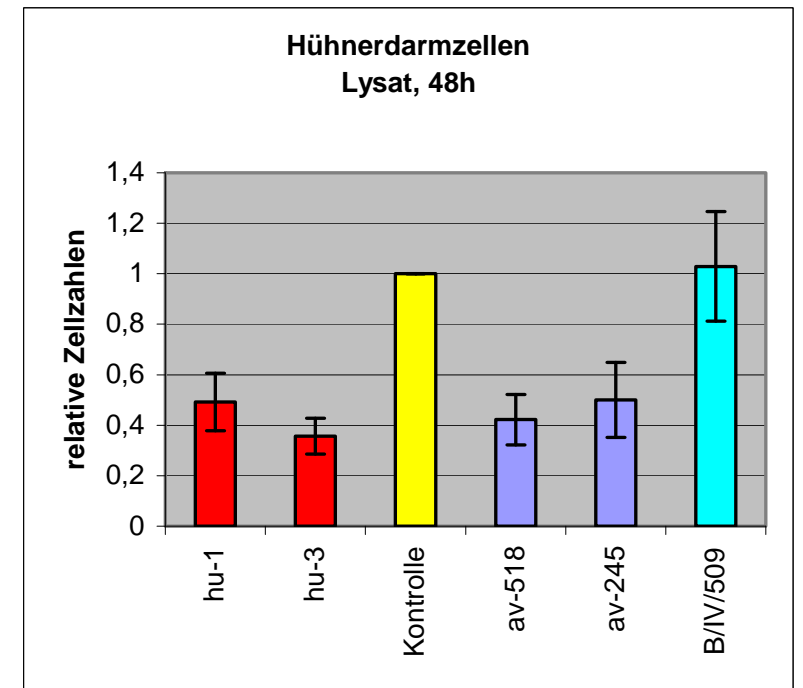

b)

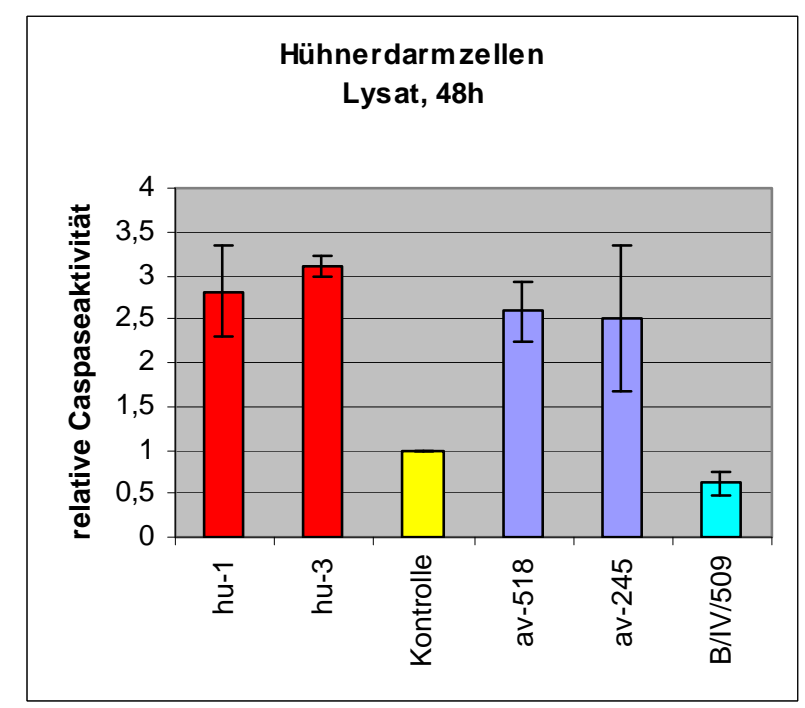

d)

Abbildung 8: Inkubation von primären Hühnerdarmzellen mit bakteriellem Lysat, Mittelwerte aus mindestens drei Versuchen, humane Isolate $=$ rot, aviäre Isolate $=$ blau bzw. türkis, Negativkontrolle $=$ gelb; relative Zellzahlen im Vergleich zur Negativkontrolle a) $24 \mathrm{~h}$ nach Infektion b) $48 \mathrm{~h}$ nach Infektion; relative Caspase-3-Aktivität c) $24 \mathrm{~h}$ nach Infektion d) $48 \mathrm{~h}$ nach Infektion

Ähnliche Resultate, wie für die primären Hühnerdarmzellen, ergaben sich auch gegenüber den Caco-2-Zellen (Abb.9). Die relativen Zellzahlen der mit Lysat von den toxinproduzierenden Stämmen behandelten Proben ergaben keine signifikanten Unterschiede zueinander. Die relativen Caspase-3-Aktivitäten lagen zu beiden Messpunkten etwa zwei- bis zweieinhalbfach über der unbehandelten Negativkontrolle. Lichtmikroskopisch zeigten diese Zellen außerdem die charakteristische der Toxinwirkung zugeschriebene Zellschwellung (Johnson und Lior 1988). Lysat des Cdt-negativen Stammes B/IV/509 ergab hingegen keinen Unterschied zur Negativkontrolle hinsichtlich Morphe und relativer Zellzahl. Jedoch zeigte sich hier zu beiden Messpunkten eine zwar nur geringfügig, aber signifikant erhöhte relative Caspase-3-Aktivität. 


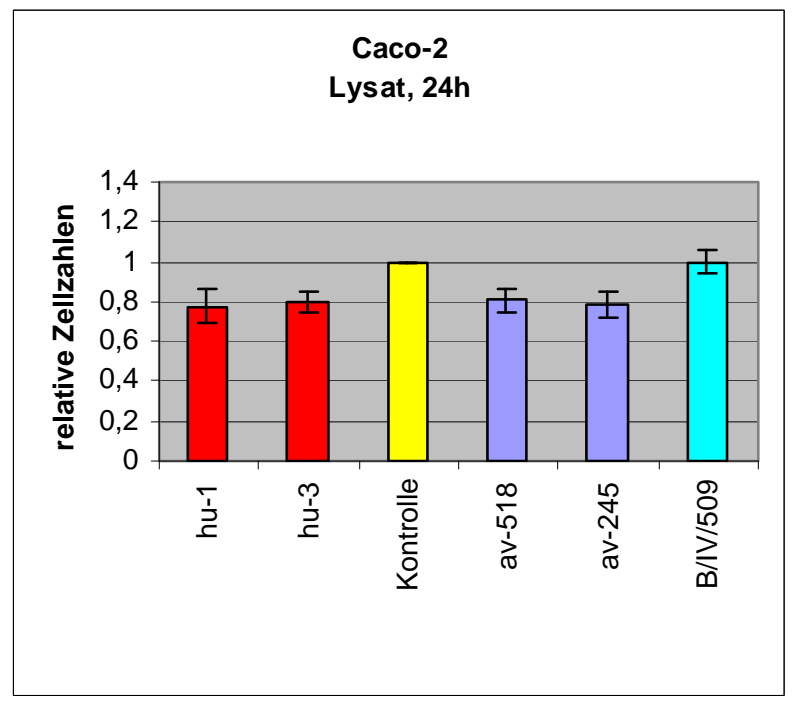

a)

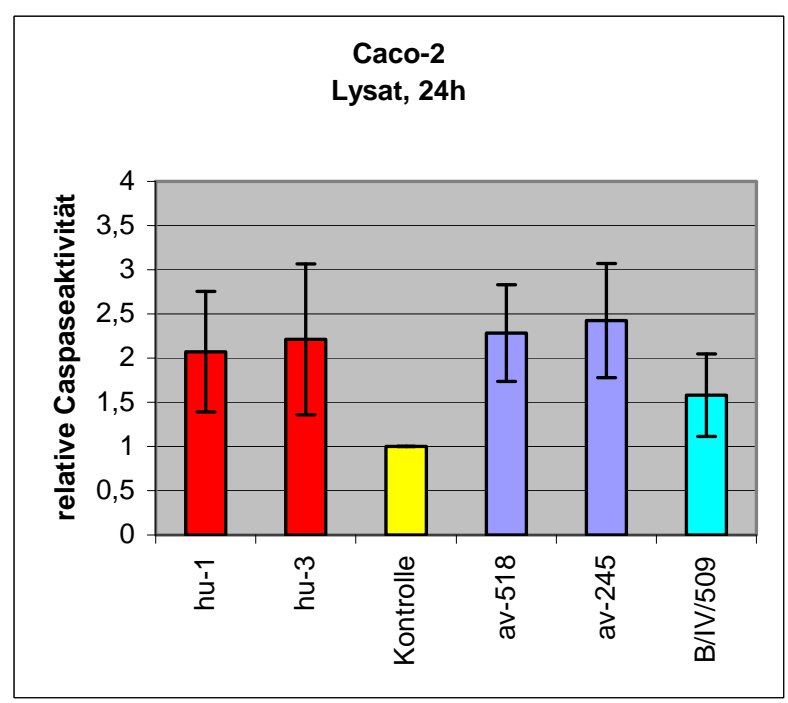

c)

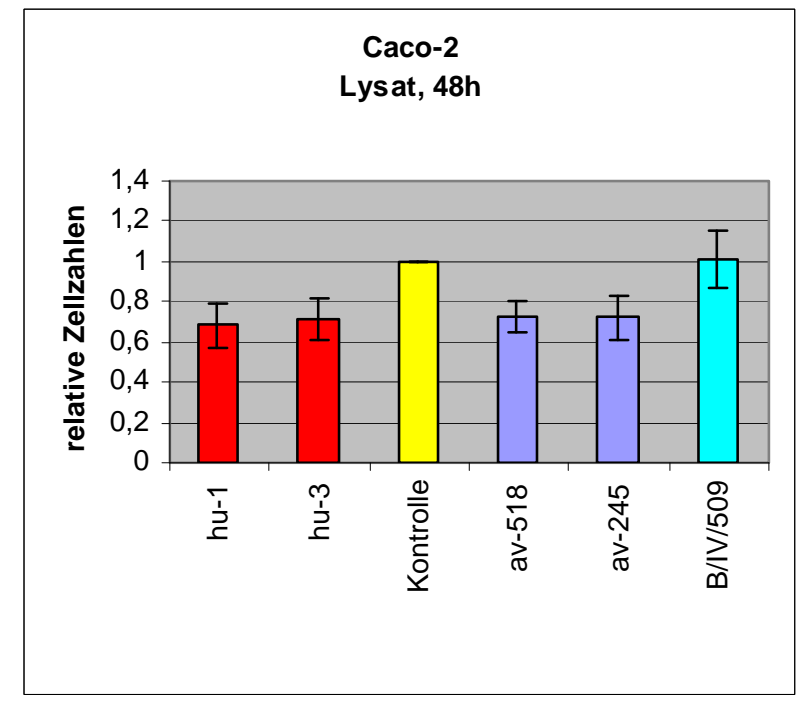

b)

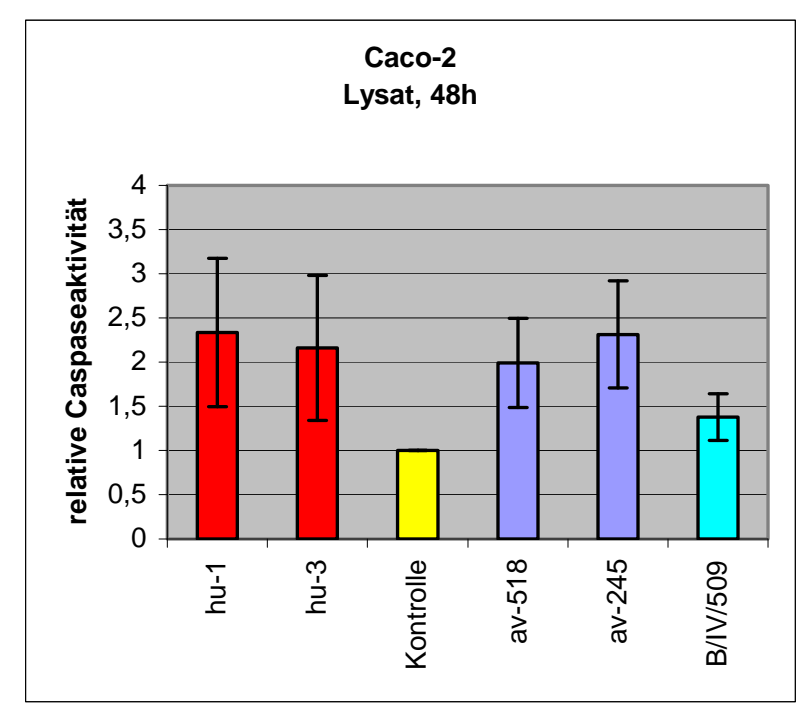

d)

Abbildung 9: Inkubation von Caco-2-Zellen mit bakteriellem Lysat, Mittelwerte aus mindestens drei Versuchen, humane Isolate = rot, aviäre Isolate $=$ blau bzw. türkis, Negativkontrolle $=$ gelb; relative Zellzahlen im Vergleich zur Negativkontrolle a) $24 \mathrm{~h}$ nach Infektion b) $48 \mathrm{~h}$ nach Infektion; relative Caspaseaktivität c) $24 \mathrm{~h}$ nach Infektion d) $48 \mathrm{~h}$ nach Infektion

In der Zusammenschau der Ergebnisse erscheint die Wirkung von Inkubation mit Lysaten der toxinproduzierenden Campylobacter-Isolate von unterschiedlicher Herkunft und Invasionsvermögen gegenüber beiden Zelltypen hinsichtlich der erreichten relativen Caspase3-Aktivitäten vergleichbar. Die relativen Zellzahlen im Vergleich zur unbehandelten Negativkontrolle zeigten sich bei den behandelten primären Hühnerdarmzellen etwas stärker verringert als bei den Caco-2-Zellen. Hierbei gilt es aber zu beachten, dass diese Zellen nicht nur einer anderen Wachstumskinetik folgen, sondern als primäre Zellen auch eine höhere Empfindlichkeit gegenüber äußeren Einflüssen und darüberhinaus noch intakte Proliferationsregulaturmechanismen besitzen. So stellten die Epithelzellen der unbehandelten Negativkontrolle nach dem 24h-Messpunkt mit dem Erreichen einer dichten und konfluenten 
Zellschicht jegliche weitere Teilungen ein. Bei den Caco-2-Zellen hingegen handelt es sich um eine Krebszelllinie, deren Replikationsrate höher und deren Empfindlichkeit gegenüber schädigenden Einflüssen geringer ist als die primärer Zellen. Folglich ist es schwierig, aus diesen Ergebnissen generelle Aussagen über Unterschiede in der Wirkung von Cdt auf Zellen humanen oder aviären Ursprungs zu treffen.

\subsection{Bestimmung der Mitose- und Apoptose-Raten im Immunfluoreszenzverfahren}

Um die in den Versuchen 3.2 und 3.3 erzielten Resultate vergleichen und ihre Auswirkungen direkter quantifizieren zu können, wurden Apoptose- und Mitose-Raten der verwendeten Zellen nach bakterieller Infektion bzw. Inkubation mit bakteriellem Lysat mittels Immunfluoreszenzverfahren bestimmt. Getestet wurde in drei Ansätzen jeweils:

(i) Inkubation mit Lysat der Stämme hu-3, av-518 und B/IV/509 (Proteinkonzentration im Medium: 58,82 (+/- 10,30) $\mu \mathrm{g} / \mathrm{ml})$,

(ii) Infektion mit Bakterien der Stämme hu-3, av-518 und B/IV/509

(MOI: 300, Inkubationsmedium plus Gentamicin $(20 \mu \mathrm{g} / \mathrm{ml}))$ und

(iii) Inkubation mit Lysat (s.o.) plus Infektion mit Bakterien (s.o.)

Nach 24 Stunden zeigten gegenüber beiden Zelltypen weder die Inkubation mit Lysat noch die Infektion mit Bakterien des Cdt-negativen Stammes B/IV/509 einen signifikanten Effekt hinsichtlich einer Veränderung der Apoptose- oder Mitose-Raten im Vergleich zur unbehandelten Negativkontrolle (Abb.10). Inkubation mit Lysaten der beiden toxinproduzierenden Stämme bewirkte hingegen deutliche und miteinander vergleichbare Veränderungen des zellulären Wachstums, wobei die Caco-2-Zellen nach 24h mit nur einer geringfügigen Steigerung der Apoptose-Rate jedoch bereits starken Reduktion der MitoseRate reagierten. Die primären Hühnerdarmzellen entwickelten hingegen bereits zu diesem frühen Messpunkt eine deutliche Steigerung der Apoptose-Rate. Mitosen fanden hier gar nicht mehr statt, was zum einen erneut die größere Empfindlichkeit der primären Zellen unterstreicht, zum anderen auf vergleichbare Lysateffekte der beiden toxinproduzierenden Isolate schließen lässt. 


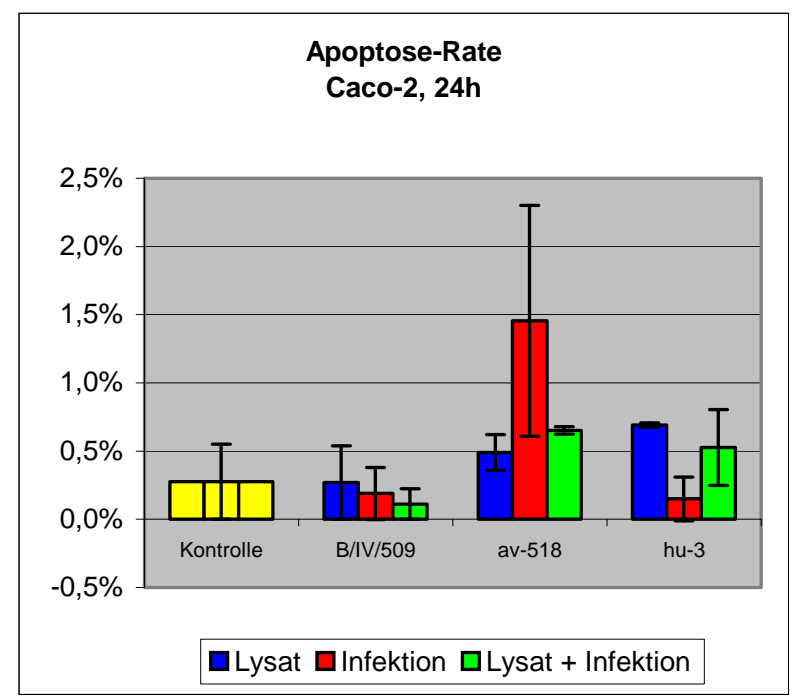

a)

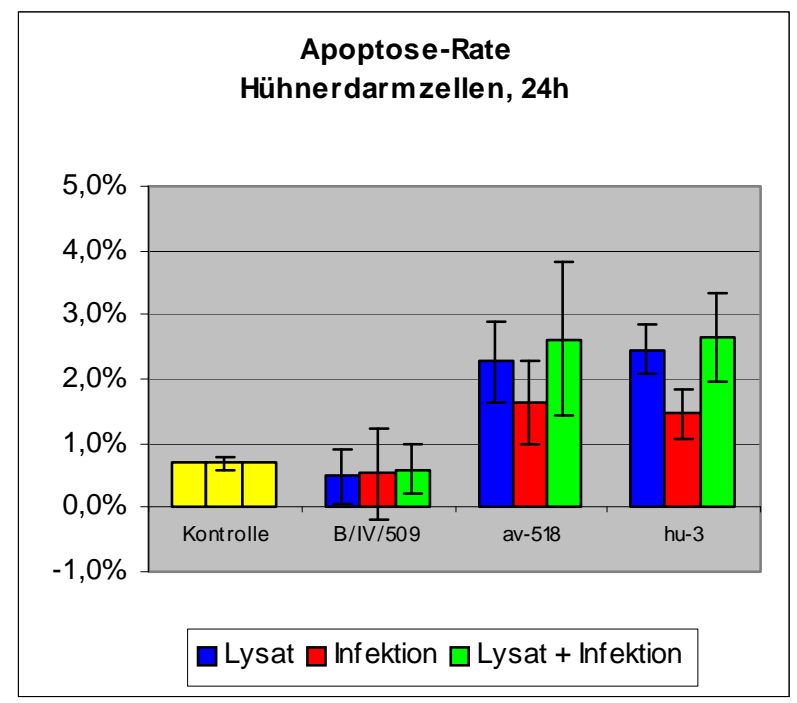

c)

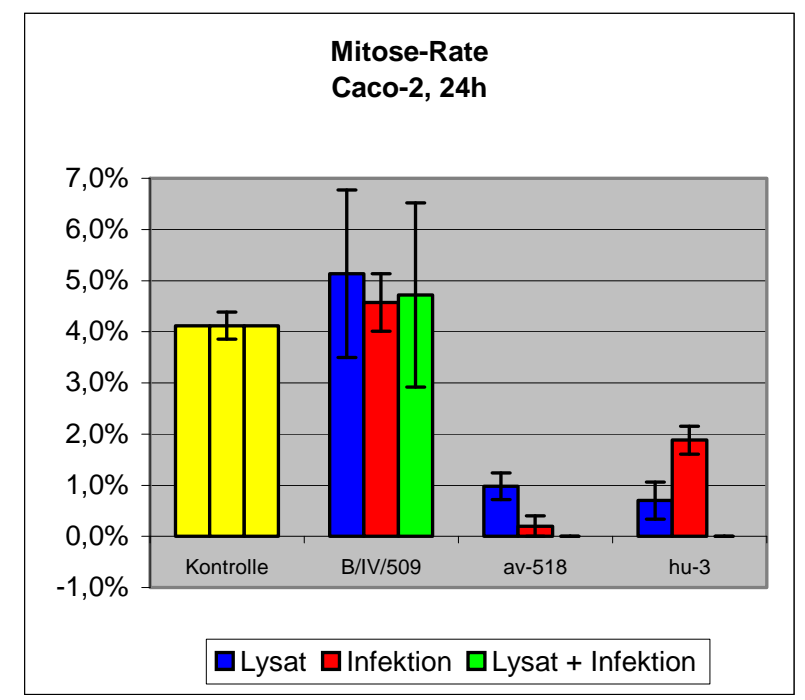

b)

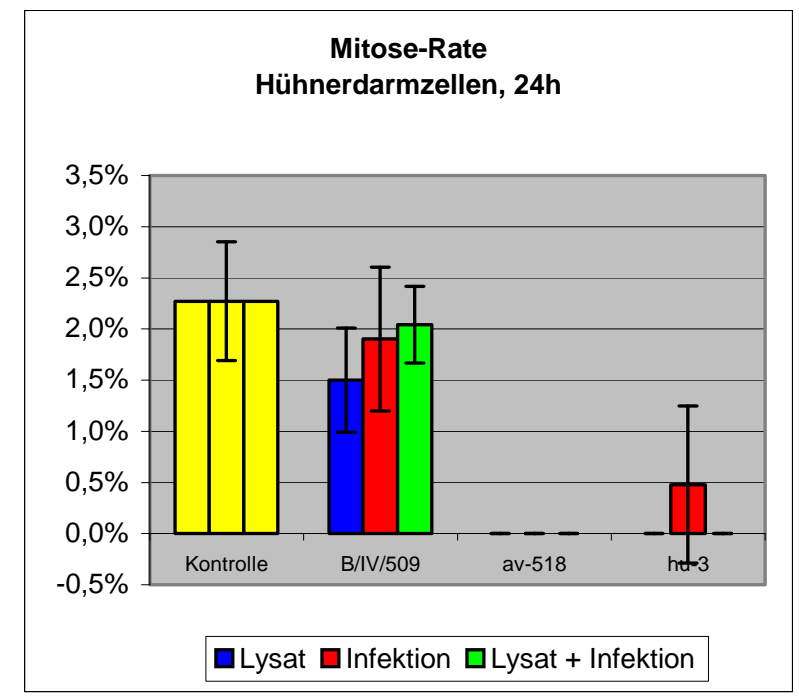

d)

Abbildung 10: Immunofluoreszenzverfahren: Vergleich von unbehandelter Negativkontrolle (gelb), Inkubation mit bakteriellem Lysat (blau), Infektion (rot) und Inkubation plus Infektion (grün) der Stämme hu-3, av-518 und B/IV/509, a) Apoptose-Rate Caco-2-Zellen (24h), b) Mitose-Rate Caco-2-Zellen (24h), c) Apotoserate primäre Hühnerdarmzellen (24h), d) Mitose-Rate primäre Hühnerdarmzellen (24h)

Eine Infektion mit Bakterien der Stämme av-518 bzw. hu-3 zeigte andererseits erneut die, durch die stark differierenden Invasioneffizienzen zu erwartenden, Unterschiede auf. Der hochgradig invasive Stamm av-518 verursachte gegenüber Caco-2-Zellen bereits nach $24 \mathrm{~h}$ einen ausgeprägten Anstieg der Apoptose-Raten, Mitosen fanden nahezu keine mehr statt. Hingegen zeigte Infektion mit hu-3 zu diesem Messpunkt noch keinen signifikanten Effekt auf Apoptosen, jedoch eine deutliche Reduktion der Mitosen. In primären Hühnerdarmzellen steigerte eine Infektion mit beiden Stämmen die Apoptose-Raten zu einem vergleichbaren Grad, jedoch nicht so stark wie durch Inkubation mit bakteriellem Lysat. Mitosen wurden hingegen durch Infektion mit dem stark-invasiven Stamm av-518 vollständig verhindert, wobei zum Messzeitpunkt nahezu 100\% der Zellen infiziert waren. Die Infektion mit dem 
mäßig-invasiven Stamm hu-3 verursachte immerhin noch eine signifikante Reduktion der Mitose-Raten, wobei jedoch berücksichtigt werden muss, dass hierbei nicht alle Zellen infiziert waren.

Im dritten Versuchsansatz, in welchem nach der Infektion zusätzlich mit bakteriellem Lysat des gleichen Isolates inkubiert wurde, zeigten sich die Resultate gegenüber beiden Zelltypen nach $24 \mathrm{~h}$ bezüglich Apoptose-Induktion mit dem ersten Versuchsansatz (nur Lysat) vergleichbar. Mitosen traten hingegen sowohl bei den primären Hühnerdarmzellen als auch insbesondere bei den Caco-2-Zellen überhaupt nicht mehr auf, was hier einen additiven Effekt von Infektion und Inkubation vermuten lässt. Eine Infektion plus Inkubation mit Lysat des Cdt-negativen Stammes B/IV/509 zeigte weiterhin keinen Effekt auf Mitose- und ApoptoseRate der beiden untersuchten Zelltypen.

Auch zum zweiten Messpunkt nach 48 Stunden führten in beiden Zelltypen weder Infektion, Inkubation mit Lysat noch die Kombination aus beiden mit dem Cdt-negativen Stamm B/IV/509 gegenüber beiden Zelltypen zu einem Anstieg der Apoptose-Raten (Abb.11). Die Mitose-Raten schienen hingegen leicht, jedoch nicht signifikant, verringert zu sein.

Eine Inkubation mit Lysaten der toxinbildenden Stämme av-518 und hu-3 führte nach $48 \mathrm{~h}$ bei beiden Zelltypen $\mathrm{zu}$ einem deutlichen und untereinander vergleichbaren Anstieg der Apoptose-Raten um den Faktor zwei- bis dreieinhalb im Vergleich zur unbehandelten Negativkontrolle. Mitosen wurden durch beide Lysate bei den Caco-2-Zellen ebenfalls nahezu vollständig, bei den Hühnerdarmzellen vollständig verhindert und traten auch zu späteren Beobachtungszeitpunkten nicht mehr auf.

Die mit dem invasiveren Stamm av-518 infizierten Proben beider Zelltypen zeigten im Vergleich weiterhin stärkere Anstiege der Apoptose-Raten bzw. Verhinderung sämtlicher Mitosen, obwohl sich der Effekt einer Infektion mit Stamm hu-3 hier dem des hochgradig invasiven Stammes av-518 langsam annäherte. Mitosen traten nur noch zu einem äußerst geringen Prozentsatz auf.

Im dritten Ansatz aus Infektion plus anschließender Inkubation mit bakteriellem Lysat zeigten sich nach $48 \mathrm{~h}$ für die beiden toxinproduzierenden Isolate ähnliche Effekte hinsichtlich Apoptose-Induktion wie bereits zum vorausgegangenen Messpunkt. Die induzierten 
Apoptose-Raten waren mit denen des ersten Versuchsansatzes vergleichbar. Mitosen traten bei beiden Zelltypen nicht mehr auf.

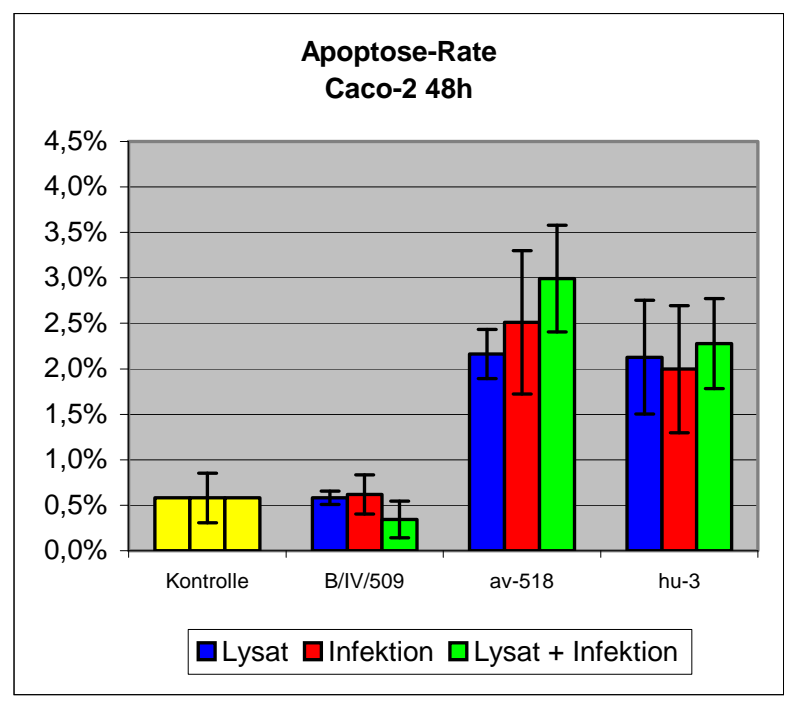

a)

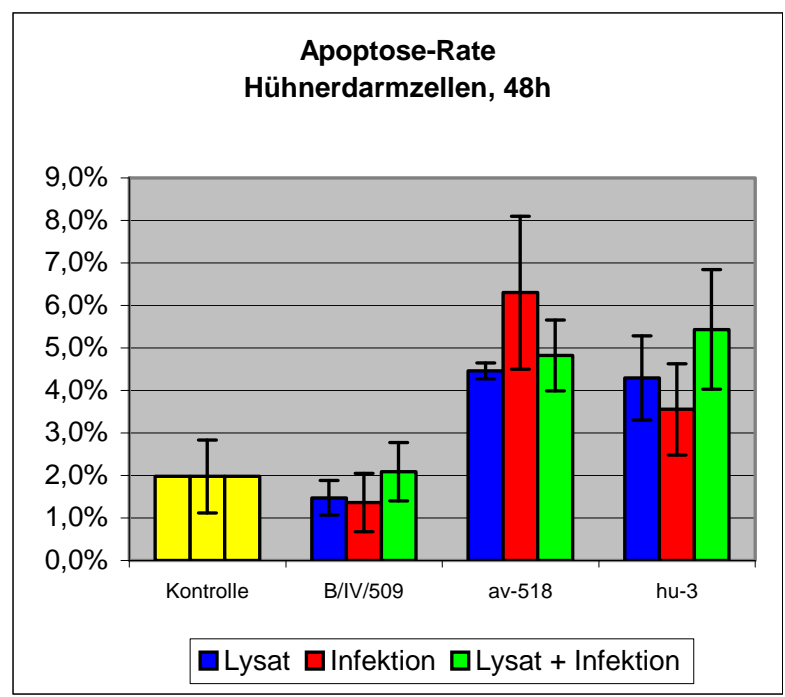

c)

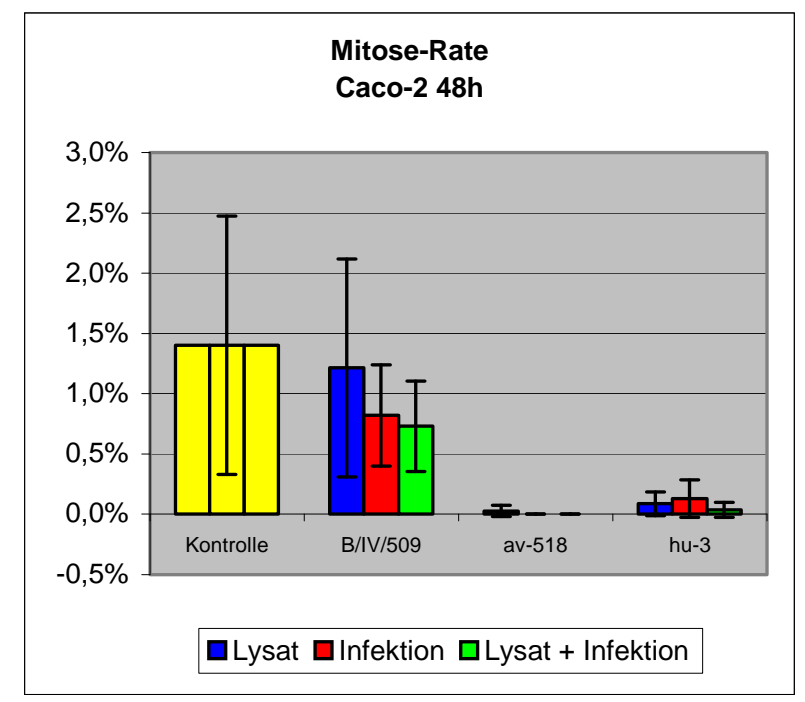

b)

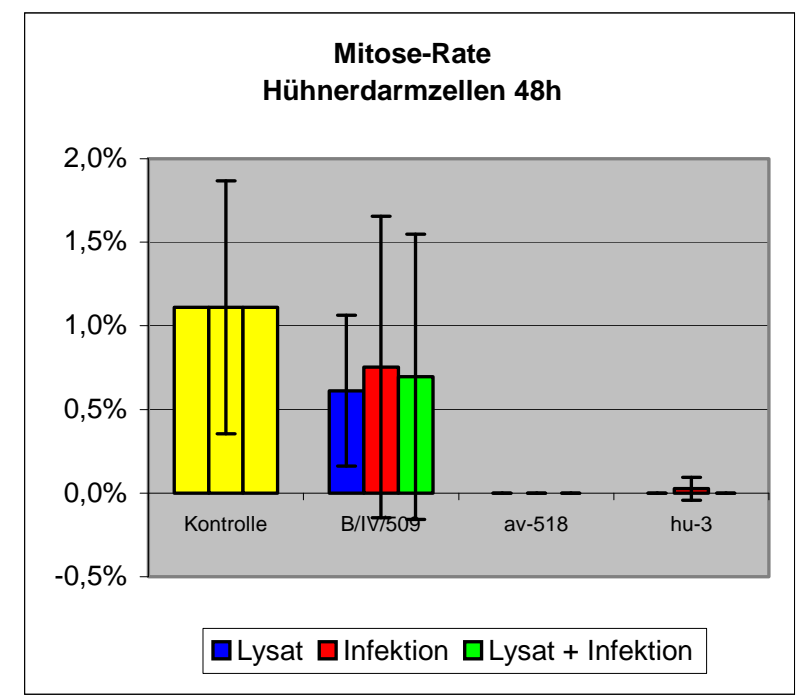

d)

Abbildung 11: Immunfluoreszenzverfahren: Vergleich von unbehandelter Negativkontrolle (gelb), Inkubation mit bakteriellem Lysat (blau), Infektion (rot) und Inkubatio plus Infektion (grün) der Stämme/Isolate hu-3, av-518 und B/IV/509, a) Apoptose-Rate Caco-2-Zellen (48h), b) Mitose-Rate Caco-2-Zellen (48h), c) Apoptoserate primäre Hühnerdarmzellen (48h), d) Mitose-Rate primäre Hühnerdarmzellen (48h)

Zusätzlich zur oben verwendeten Methode, in welcher der Effekt einer Infektion bzw. Inkubation des Versuchsansatzes in der prozentualen Wirkung auf das gesamte Kollektiv der Zellen gemessen wurde, sollte die Wirkung einer Infektion auch für die einzelne infizierte Zelle untersucht werden. Aufgrund des großen zeitlichen Aufwandes und methodisch bedingter Schwierigkeiten in der Bearbeitung der primären Hühnerdarmzellen, aber auch aufgrund der repräsentativen Resultate, wurden hierfür Caco-2-Zellen zum Messpunkt 48h nach Infektion ausgewählt (Tab.5). Zu diesem Zeitpunkt waren die beobachteten Effekte 
(siehe oben) am deutlichsten nachweisbar. Für die primären Hühnerdarmzellen war dieses Verfahren aufgrund ihres ungeordneten und mehrlagigen Wachstums, welches eine genaue Zuordnung eines intrazellulären Bakteriums zu einer bestimmten Zellen mit den verwendeten Geräten nicht zuließ, leider nicht anwendbar.

Untersucht wurde, welcher Prozentsatz des gesamten Zellkollektivs infiziert war und ob in Abhängigkeit von der Fähigkeit zur Toxinproduktion eine Korrelation mit der Infektionsrate unter den apoptotischen bzw. mitotischen Zellen hergestellt werden konnte.

Tabelle 5: Anteil apoptotischer und mitotischer Caco-2-Zellen auf Einzelzellebene: Messpunkt nach 48h, Mittelwerte zweier unabhängiger, repräsentativer Experimente

\begin{tabular}{|c|c|c|c|}
\hline Stamm I Isolat & Zellen infiziert & $\begin{array}{c}\text { apoptotische Zellen, } \\
\text { Anteil infiziert }\end{array}$ & $\begin{array}{c}\text { mitotische Zellen, } \\
\text { Anteil infiziert }\end{array}$ \\
\hline B/IV/509 & $40,44 \%(+/-4,33 \%)$ & $41,18 \%$ & $37,83 \%(+/-8,83 \%)$ \\
\hline av-518 & $100,00 \%$ & $100,00 \%$ & keine mitotischen Zellen \\
\hline hu-3 & $54,92 \%(+/-2,92 \%)$ & $86,16 \%(+/-0,05 \%)$ & $9,39 \%(+/-0,82 \%)$ \\
\hline
\end{tabular}

Der Cdt-negative Stamm B/IV/509 zeigte nach 48h im Mittel einen Anteil infizierter Zellen von 40,44\% (+/- 4,33\%). Unter den apoptotischen bzw. mitotischen Zellen waren mit einem Anteil infizierter Zellen von je 41,18\% bzw. 37,83\% (+/- 8,83\%) nur geringe Abweichungen von dieser Quote zu beobachten. Eine Infektion mit diesem nicht-toxinproduzierenden Stamm übte also weder einen antimitotischen noch konsekutiv einen apoptotischen Einfluss auf die Caco-2-Zellen aus.

Wie bereits mehrfach erwähnt, zeigten sich mit dem hochgradig invasiven Stamm av-518 nach 48 Stunden nahezu alle Zellen infiziert. Demzufolge waren alle apoptotischen Zellen infiziert, Mitosen traten zum Zeitpunkt 48h nach Infektion keine mehr auf.

Bei einer Gesamtinfektionsrate aller Zellen von 54,92\% (+/- 2,92\%) ergab sich für den mäßig-invasiven Stamm hu-3 unter den apoptotischen Zellen hingegen eine Infektionsrate von 86,16\% (+/- 0,05\%), unter den mitotischen Zellen jedoch von nur 9,39\% (+/- 0,82\%). 
Zusammenfassend erwies sich Inkubation mit Lysaten der Stämme av-518 (Huhn) und hu-3 (Mensch) auch im direkten optischen Vergleich mittels Immunfluoreszenz gegenüber beiden Zelltypen als gleichermaßen wirksam hinsichtlich einer Unterbrechung des Zellzyklus' mit Inhibierung der Mitosen und konsekutiver Induktion der Apoptose. Inkubation mit Lysat des Cdt-negativen Stammes B/IV/509 zeigte hingegen keine signifikanten Effekte im Vergleich zur unbehandelten Negativkontrolle.

Die Infektion mit Bakterien der untersuchten Stämme zeigte hingegen aufgrund der bereits beschriebenen Unterschiede in der Invasionseffizienz der untersuchten Stämme variierende Resultate. Es konnte ein direkter Zusammenhang zwischen Infektion mit einem toxinproduzierenden Stamm und Verringerung der Mitose- bzw. Erhöhung der Apoptose-Rate und ein Ausbleiben solcher Effekte im Falle einer Infektion mit einem Cdt-negativen Stamm gezeigt werden. Auch scheint es, dass mit einem sich vergrößernden zeitlichen Intervall zwischen bakterieller Infektion und Messpunkt der relative Toxineffekt auf ein Zellkollektiv hinsichtlich Apoptose-Induktion im Vergleich zur Inkubation mit bakteriellem Lysat zunimmt. Augenscheinlich geschieht dies aufgrund einer fortlaufenden Toxinproduktion der Bakterien bei prolongiertem intrazellulären Überleben und weiterer Replikation. Eine Infektion plus Inkubation mit bakteriellem Lysat zeigte für die zunächst auftretende Unterbrechung des Zellzyklus mit Verhinderung der Mitose additive Effekte; bei der verzögert eintretenden Apoptose ergab sich im Vergleich mit den Einzelansätzen jedoch kein signifikanter Unterschied.

Ein direkter Vergleich der Wirkung des Cdt von Campylobacter jejuni auf Caco-2-Zellen und primäre Hühnerdarmzellen erwies sich durch die unterschiedlichen Eigenschaften der verwendeten Zelltypen naturgemäß als schwierig. Schon im alltäglichen Gebrauch zeigte sich die Caco-2-Tumorzelllinie gegenüber äußeren Einflüssen als wesentlich widerstandsfähiger. Auch hatten die unbehandelten Negativkontrollen dieser Zellen zu jedem Zeitpunkt ein größeres mitotisches Kompartiment und einen geringeren Anteil an Zellen, die von sich aus der Apoptose unterliefen (Abb.12). Die primären Hühnerdarmzellen erlitten unter vergleichbaren Kulturbedingungen hingegen schon früher einen Mitosestop mit nachfolgend vermehrtem Auftreten von Apoptosen. Berücksichtigt und relativiert man jedoch diese Aspekte, so scheinen die Auswirkungen von Infektion oder Inkubation mit Toxin auf beide Zelltypen durchaus vergleichbar. 


\section{Ergebnisse}

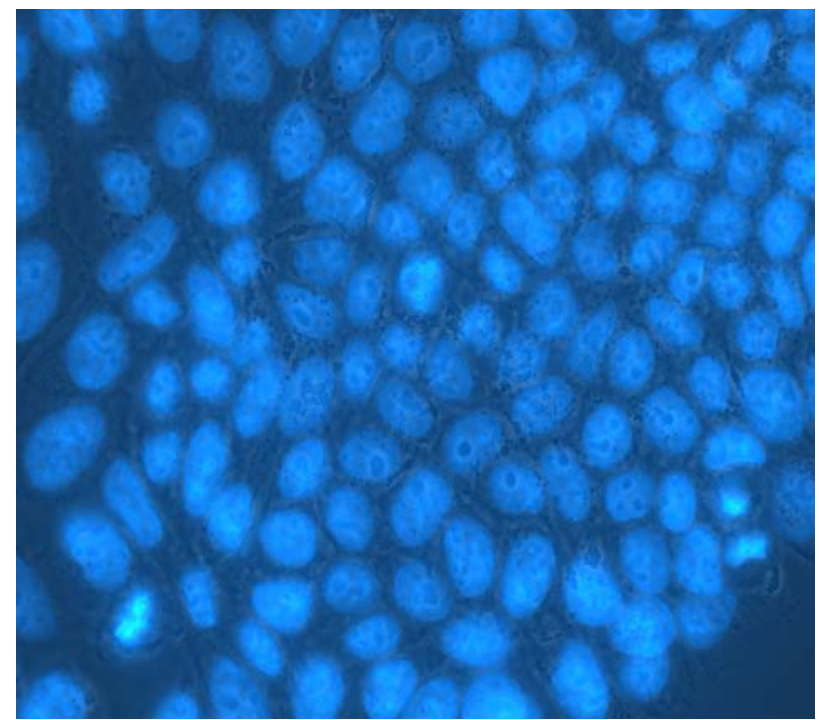

a)

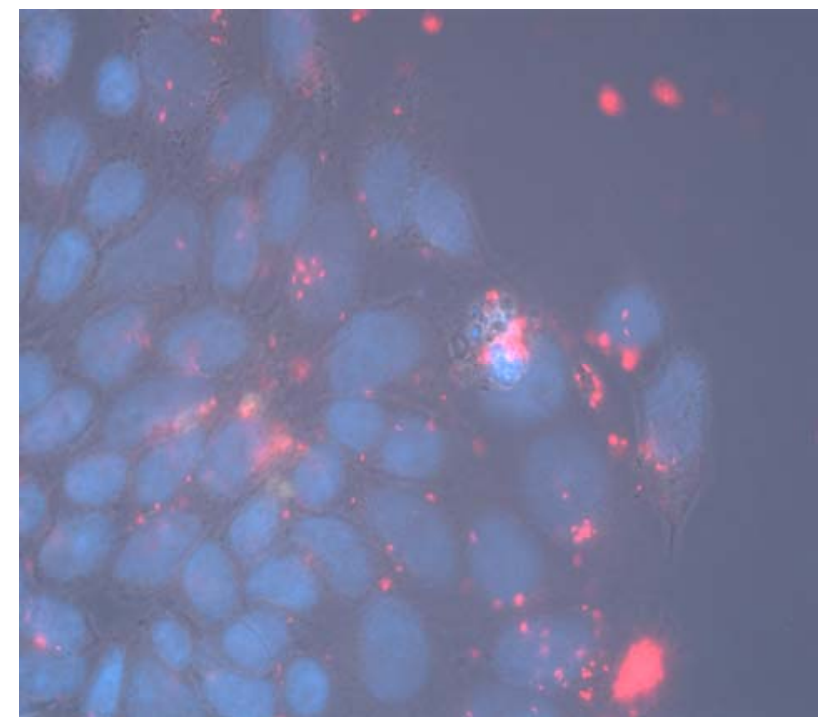

c)

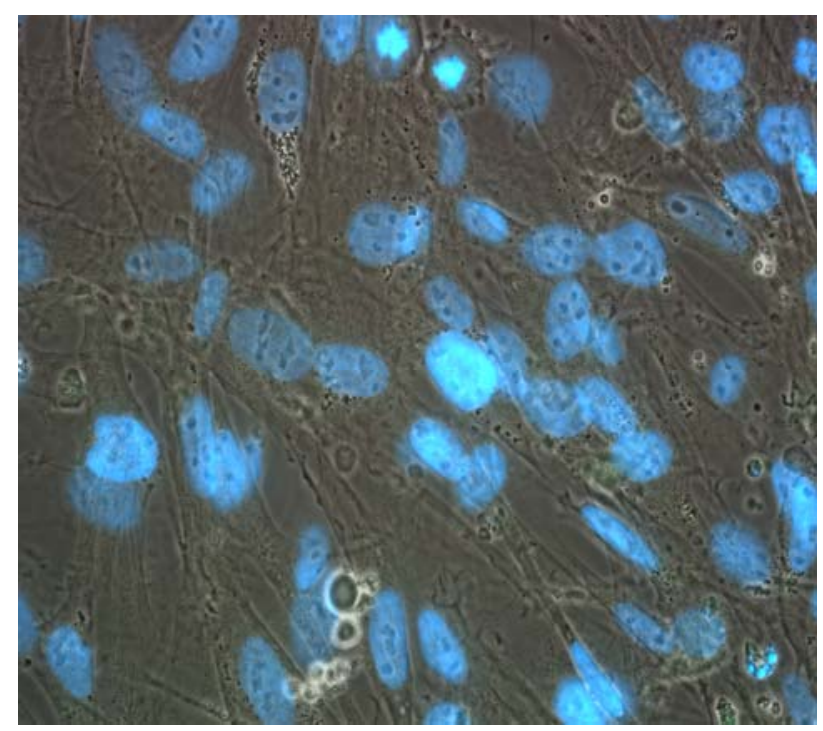

b)
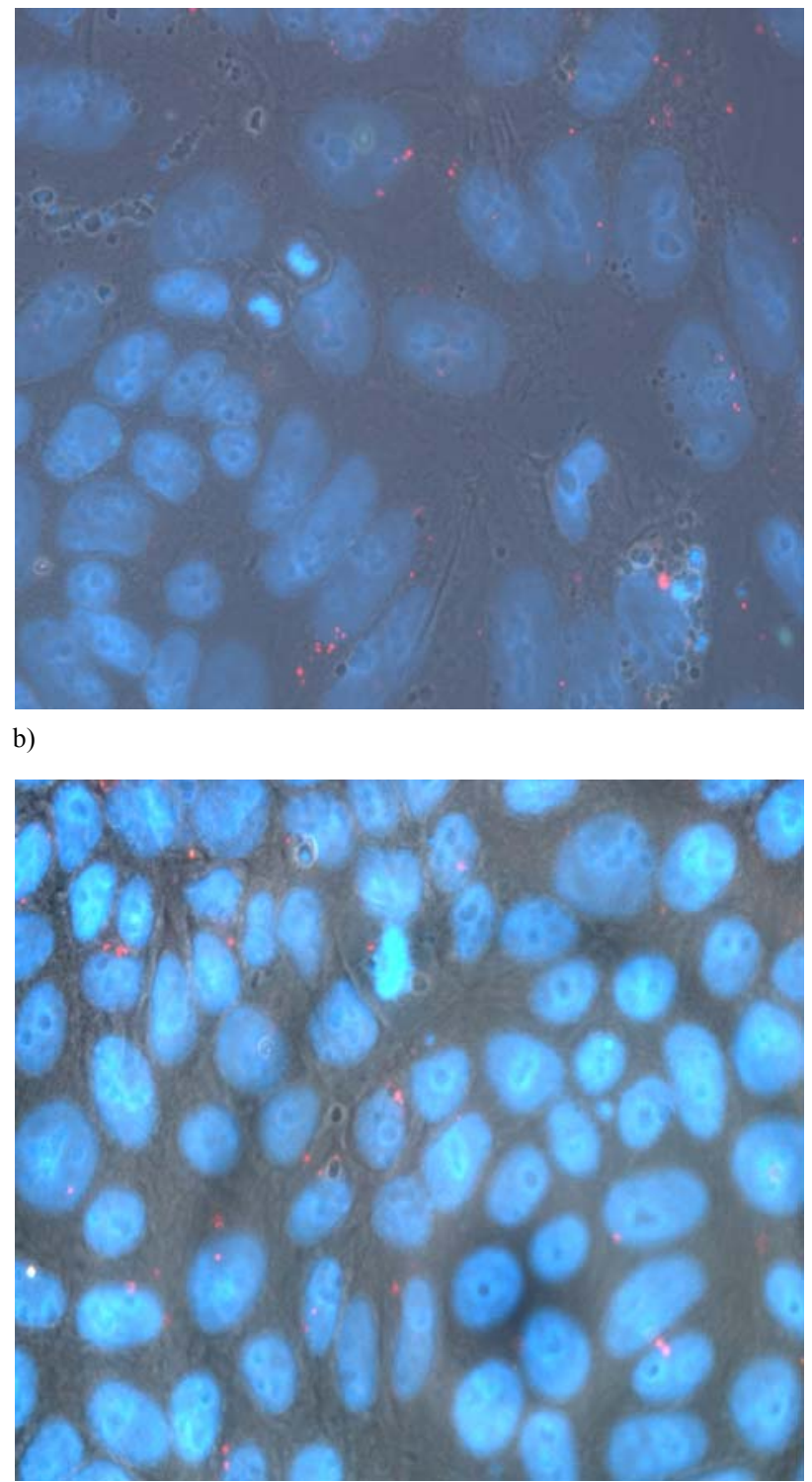

d)

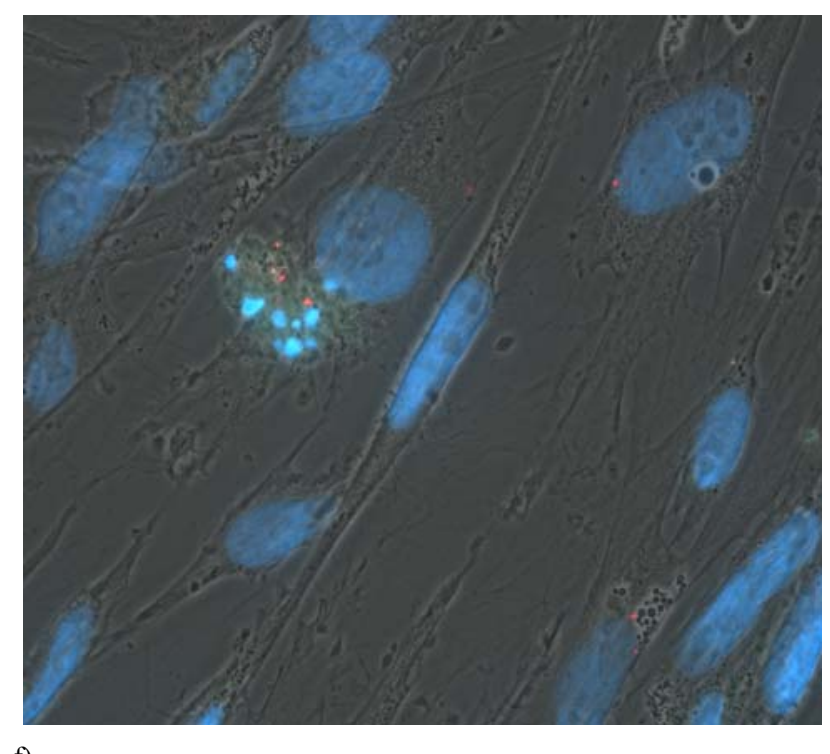

e) 


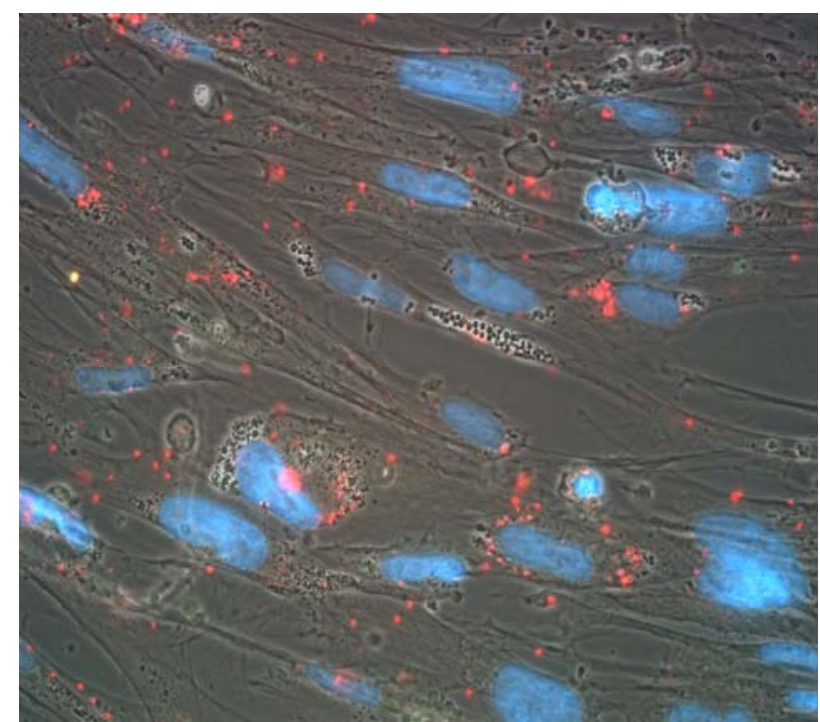

g)

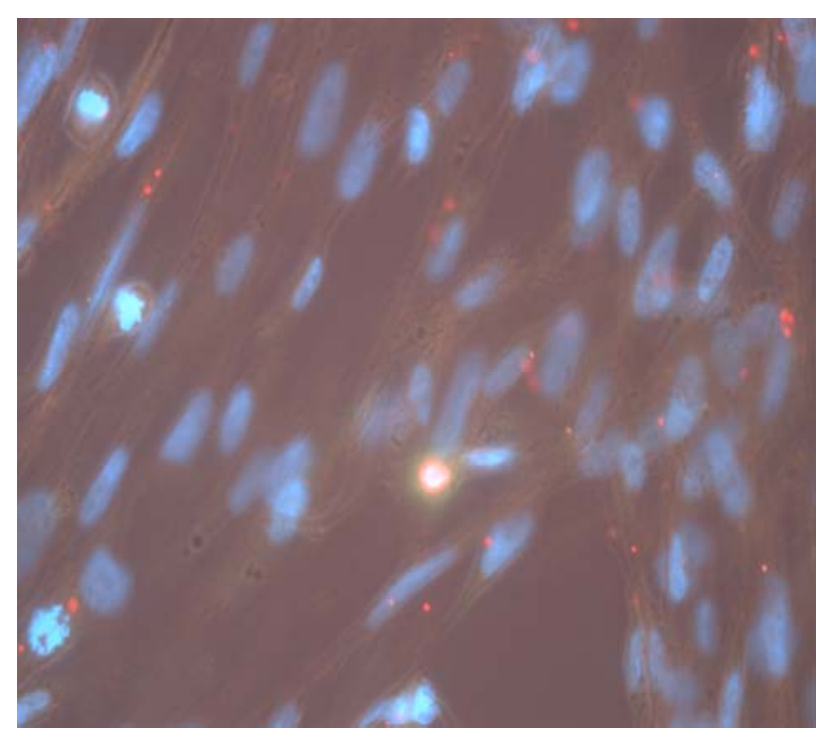

h)

Abbildung 12: Beispielhafte fluoreszenz- und phasenkontrastmikroskopische Aufnahmen der untersuchten Zellen

a) Caco-2-Zellen, Negativkontrolle: 3 Mitosefiguren in verschiedenen Stadien, einschichtiges Zellwachstum

b) Caco-2-Zellen, infiziert mit Isolat hu-3: Mitose einer nicht infizierten Zelle (links oben), Apoptose einer infizierten Zelle (rechts unten) erkennbar an charakteristischen apoptotic bodies

c) Caco-2-Zellen, infiziert mit Stamm av-518: Apoptose einer mehrfach infizierten Zelle (Bildmitte), deutlich erkennbar das vergleichsweise hohe Invasionsvermögen des Stammes av-518

d) Caco-2-Zellen, infiziert mit dem Cdt-negativen Stamm B/IV/509: Mitose einer Zelle trotz Infektion (Bildmitte oben)

e) Hühnerdarmzellen, Negativkontrolle: Mitosefigur (Bildmitte oben), apoptotische Zelle erkennbar an apoptotic bodies (rechts unten), mehrschichtiges Zellwachstum erschwert Begutachtung

f) Hühnerdarmzellen, infiziert mit Isolat hu-3: Infizierte apoptotische Zelle in der Vergrößerung, 4 intrazelluläre Bakterien (rot), 1 extrazelluläres (gelb)

g) Hühnerdarmzellen, infiziert mit Stamm av-518: 2 beginnende Apoptosefiguren infizierter Zellen (rechts), deutlich erkennbar das vergleichsweise hohe Invasionsvermögen mit teilweise mehrfach infizierten Zellen

h) Hühnerdarmzellen, infiziert mit Cdt-negativem Stamm B/IV/509: 3 Mitosefiguren (links), davon 2 trotz Infektion

\subsection{Molekularbiologie - Vergleich der cdt-Transkription unter zellfreien Bedingungen}

Bevor die Frage behandelt wurde, welchen Einfluss das intrazelluläre Milieu nach Infektion der untersuchten humanen und aviären Zellen auf die Cdt-Transkription von Campylobacter jejuni hat, erschien es zunächst sinnvoll zu untersuchen, ob sich die Toxin-Transkription der verschiedenen Stämme bereits unter zellfreien Bedingungen unterscheidet.

Hierzu wurden vierundzwanzigstündige, auf Columbia-Blutagar unter Standardbedingungen (s.o.) gezüchtete, Bakterienkulturen verwendet. Die gewählte Dauer der Inkubationszeit nach Rekultivierung gewährleistete, dass die Stämme unter vergleichbaren und optimalen Bedingungen ihren individuellen Stoffwechsel entfalten konnten, sich jedoch noch nicht in der lag-Phase oder Absterbephase des Vermehrungszyklus der bakteriellen Kolonien befanden. 


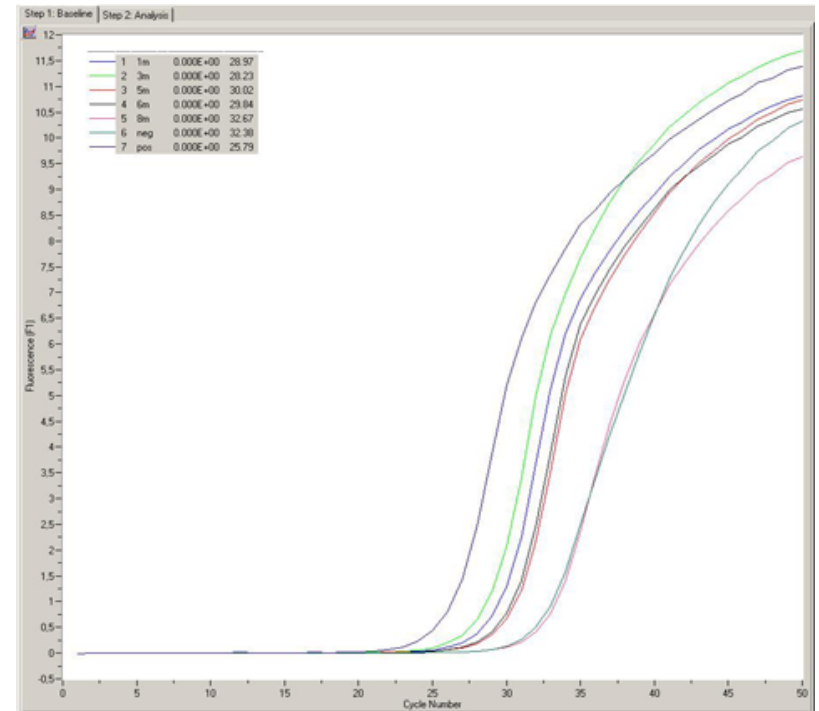

a)

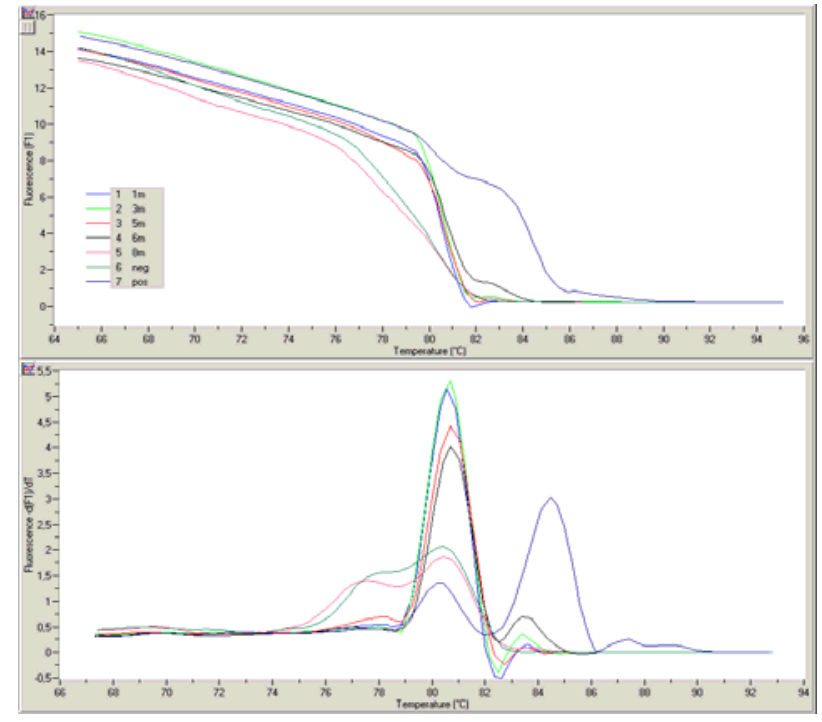

b)

Abbildung 13: Beispielhafte Darstellung des LightCycler-Analysesoftwareprogramms, Protokoll OneStep B, RNA-Proben der Stämme hu-1, hu-3, av-518, av- 245, B/IV/509, Negativ- und Positivkontrolle, a) Crossingpoint-Analyse b) Schmelzpunktanalyse

In zwei unabhängigen Experimenten wurden die Stämme hu-1, hu-3, av-518, av-245, B/IV/509 und der Referenzstamm 81-176 untersucht und (wie in Abschnitt 2.2.6.1 beschrieben) behandelt (Abb.13).

Probleme ergaben sich hierbei durch die geringen $c d t$-RNA-Mengen, vor allem nach Isolation aus internalisierten intrazellulären Bakterien (siehe auch Experimente 3.6 und 3.7), welche sich im unteren Grenzbereich der Nachweisbarkeit befanden. Dies führte konsekutiv zu größeren Schwankungen und Unsicherheiten in der Bestimmung, da sich die PCR-Reaktionen bei der Entwicklung eines spezifischen Produktes jenseits des optimalen Konzentrationsbereichs befanden und mit höheren Reaktionszyklenzahlen unspezifische Produkte die Messung störten.

Die Proben des Stammes B/IV/509 konnten zwar mit denen der übrigen Stämme auf 16SrRNA normiert werden, jedoch konnte - erwartungsgemäß - in keinem Experiment mit diesem Stamm die Expression von Transkripten für $c d t A$, $c d t B$ oder $c d t C$ nachgewiesen werden. Mittels genomischer DNA gelang hingegen der Nachweis der Toxingene $c d t B$ und cdtC. Da die drei cdt-Gene bei Campylobacter jejuni in einem polycistronischen Operon angeordnet sind, fehlt dem Stamm B/IV/509 neben dem Gen cdtA vermutlich auch die genaufwärts befindliche Promotorsequenz, weshalb es zu keiner Transkription einer cdtmRNA kommt. Da es für die übrigen Isolate durch die Transkription der drei polycistronisch angeordneten $c d t$-Gene in dieselbe mRNA in den PCR-Einzelbestimmungen der Gene zu 
zueinander proportionalen Messergebnissen kommen sollte, wurde zusätzlich ein Mittelwert aus den drei Messwerten berechnet, um Ausreißer durch Handhabungs- oder Messungenauigkeiten zu kompensieren.

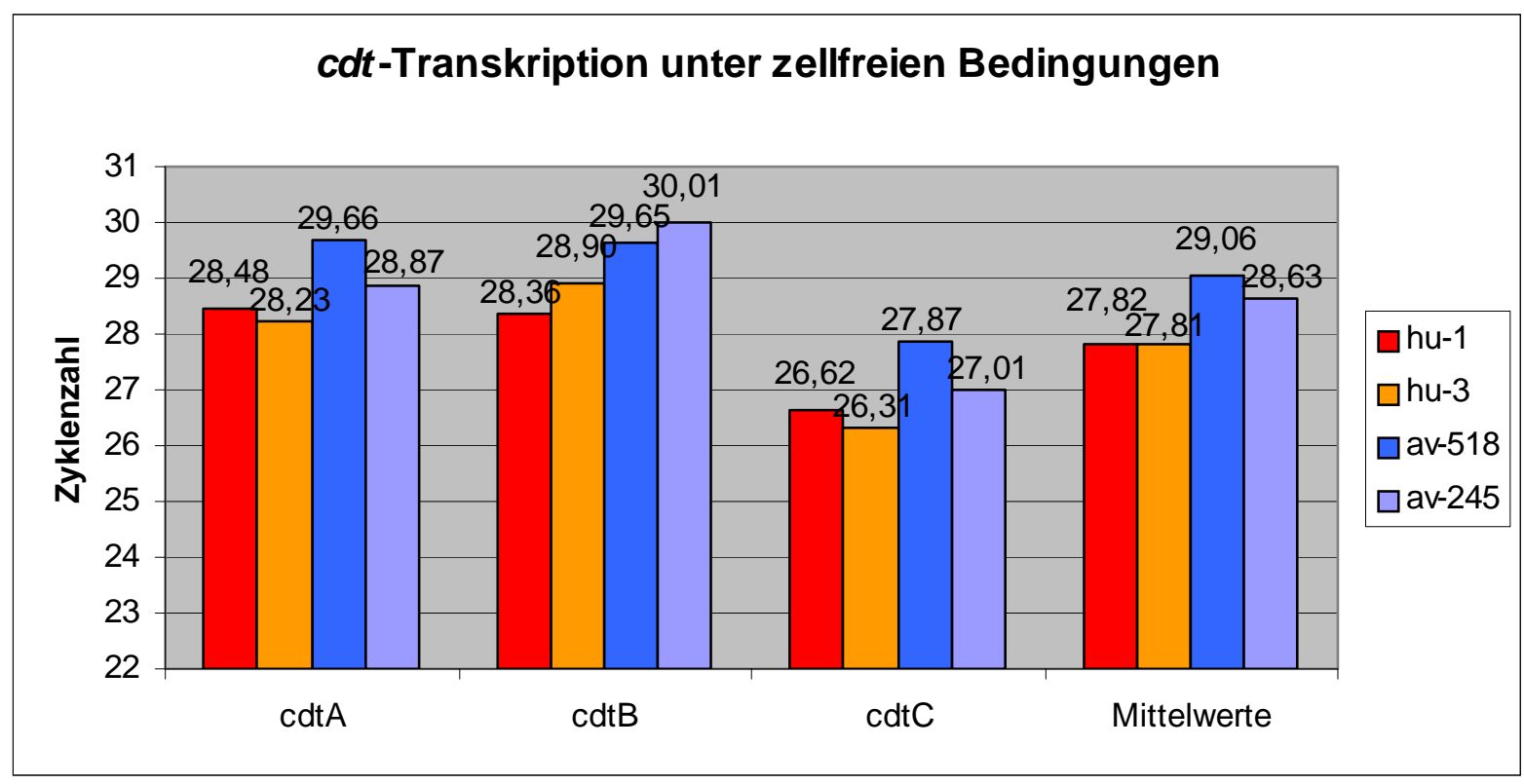

Abbildung 14 :Vergleich der $c d t$-Transkription ( $c d t A, c d t B, c d t C$ und Mittelwerte) der untersuchten humanen und aviären Isolate unter zellfreien Bedingungen (24h Inkubation auf Columbia-Blutagar unter Standardbedingungen) mittels OneStep-RT-PCR, Mittelwerte der Crossingpoint-Zyklenzahl aus zwei unabhängigen Experimenten

Im Vergleich der verbliebenen vier Proben zeigten die beiden humanen Isolate gegenüber den aviären Isolaten tendenziell geringfügig verringerte Reaktionszyklenzahlen, d.h. größere RNA-Ausgangsmengen der drei untersuchten cdt-Gene (Abb.14). Nach Berechnung der Mittelwerte für die drei cdt-Messungen aus zwei unabhängigen Experimenten ergaben sich für die Stämme hu-1 und hu-3 nahezu identische Ergebnisse mit 27,82 bzw. 27,81 Zyklen, die Stämme av-245 und av-518 benötigten hingegen 28,63 bzw. 29,06 Zyklen. Die Differenz zwischen hu-1/hu-3 und av-245 bzw. av-518 betrug 0,82 bzw. 1,25 Zyklen und ergab nach der im Methodenteil beschriebenen Formel (bei einem Exponenten von 1,8) einen Unterschied der RNA-Ausgangsmengen um den Faktor 1,61 bzw. 2,09.

Bedingt durch die methodischen Einschränkungen sind diese Differenzen allerdings zu gering, um als signifikant bewertet zu werden. Bei anzunehmenden kleineren Abweichungen in der vorausgegangenen Normierung auf 16S-rRNA, welche als Ausgangsbasis für alle nachfolgenden Messungen diente, hätten sich diese potenziert, zumal 16S-rRNA als housekeeping-Gen in allen Proben in wesentlich größeren Mengen enthalten war und daher bei geringeren Zyklenzahlen (etwa 20 Zyklen) detektiert und normiert wurde. Im Umkehrschluss kann allerdings für die untersuchten vier Isolate eine größere Differenz in der $c d t$-Transkription unter Ruhebedingungen ausgeschlossen werden. 


\subsection{Molekularbiologie - Kinetik der cdt-Transkription nach Infektion}

Im nachfolgenden Experiment wurde die Entwicklung der cdt-Transkription durch Campylobacter jejuni in Abhängigkeit vom Zeitpunkt nach Infektion der Zielzelle untersucht. Verwendet wurden Caco-2-Zellen und der Campylobacter-Referenzstamm 81-176. Die Messpunkte wurden zwischen $3 \mathrm{~h}$ und $24 \mathrm{~h}$ nach Beginn der Infektion gewählt, eingegrenzt durch das Infektionsintervall plus einer Gentamicin-Mindestinkubationszeit $(2 \mathrm{~h}+1 \mathrm{~h})$ beziehungsweise die einsetzende Lyse der Zielzellen nach 24h. Als Vergleichswert der Transkriptionskonzentration diente die zur Infektion verwendete bakterielle Lösung.

Beginnend vom ersten Messpunkt nach Start der Infektion (3h) zeigte die Transkription der drei Toxingene im zeitlichen Verlauf eine absinkende Tendenz bezüglich der gemessenen Zyklenzahlen. Auch in der gemittelten Zyklenzahl der drei cdt-Messwerte ergibt sich eine kontinuierliche Reduktion der Zyklen von 32,58 (3h) auf 31,38 (24h) (Abb.15). Diese Verringerung um 1,2 Zyklen entspricht nach der im Methodenteil beschriebenen Formel (bei einem Exponenten von 1,8) einem Unterschied in der RNA-Ausgangsmenge um den Faktor 2,02. In der Vergleichsprobe aus bakterieller Lösung wurden im Mittel 31,18 Zyklen gemessen, eine Differenz von 1,4 Zyklen zum 3h-Messpunkt beziehungsweise 0,2 Zyklen zum 24h-Messpunkt. Dies entspricht einem Unterschied der RNA-Ausgangsmengen um den Faktor 2,28 beziehungsweise Faktor 1,12 zur Vergleichsprobe.

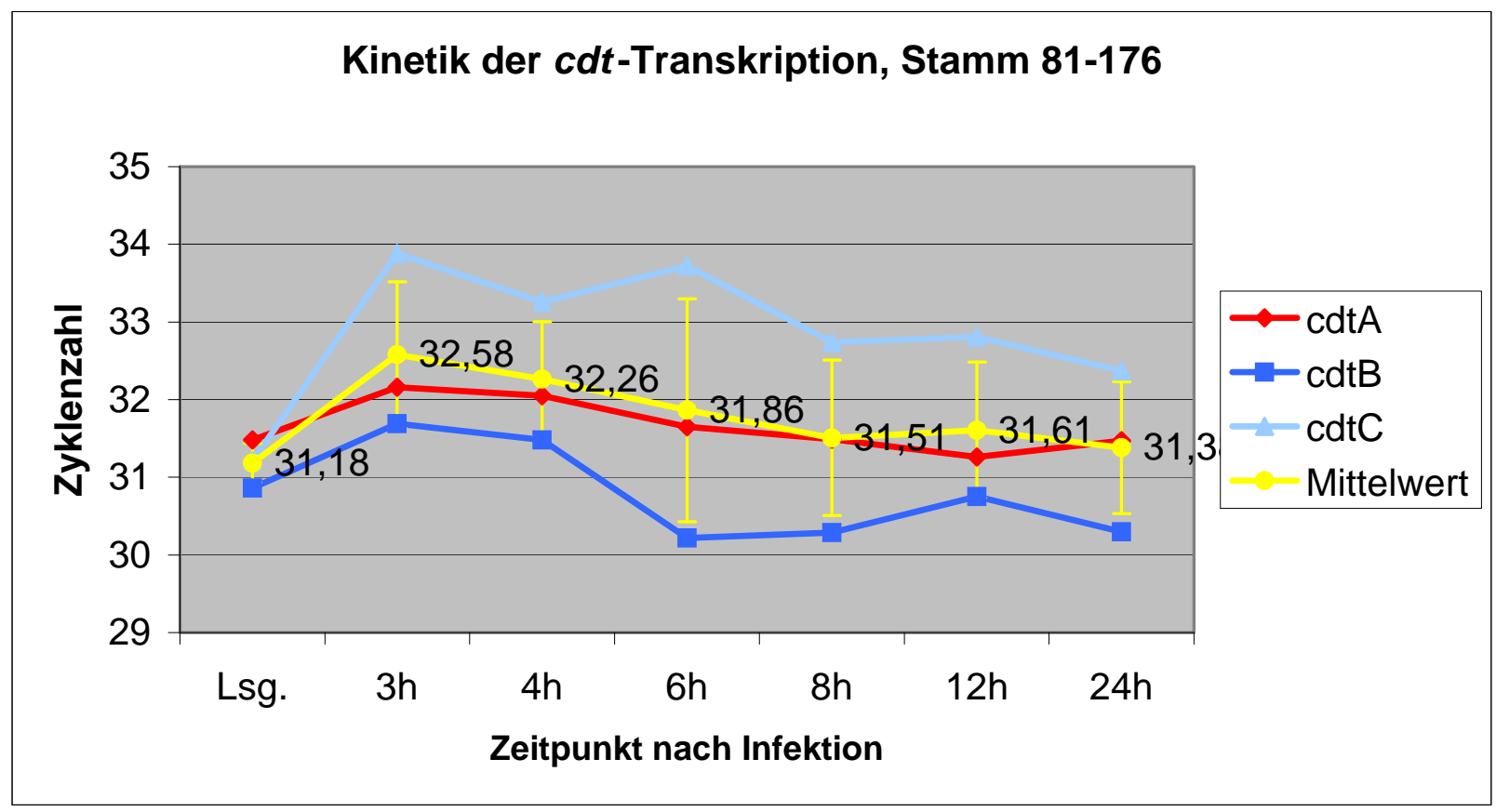

Abbildung 15: Vergleich der $c d t$-Transkription ( $c d t A, c d t B, c d t C$ und Mittelwerte) des Referenzstammes 81-176 nach Infektion in Caco-2-Zellen mittels OneStep-RT-PCR; Messpunkte: Infektionslösung, 3h, 4h, 6h, 8h, 12h und $24 \mathrm{~h}$ nach Infektion, CrossingpointZyklenzahlen eines repräsentativen Experimentes 
Auch in diesem Experiment sind die gemessenen Unterschiede nicht als signifikant zu bewerten. Auffällig ist dennoch das im zeitlichen Verlauf (von 3h nach Infektion über 24h nach Infektion bis hin zur bakteriellen Vergleichslösung unter optimalen Inkubationsbedingungen) kontinuierliche Absinken der Reaktionszyklenzahlen entsprechend einer kontinuierlichen Zunahme der cdt-mRNA-Menge von Messpunkten direkt nach Infektion der Zelle hin zu späteren Zeitpunkten beziehungsweise kulturellen Optimalbedingungen.

In einem zweiten, ergänzenden unabhängigen Versuch, in welchem nach konventioneller One-Step RT-PCR mittels eines semiquantitativen (und damit auch ungenaueren) Verfahrens die photometrische Messung der Bandenstärke der Reaktionsprodukte auf Agarosegel bestimmt wurde, zeigten sich ebenfalls keine signifikanten Unterschiede oder Tendenzen in der $c d t$-Transkription in Abhängigkeit vom Zeitpunkt nach Infektion (Abb.16). Die einzelnen Messwerte unterliefen (wie methodischerseits zu erwarten) größeren Schwankungen; der Mittelwert der drei Messungen variierte jedoch nur geringfügig um weniger als ein Viertel seines Maximalwertes. Eine Umrechnung von Bandenstärke auf Konzentrationsunterschiede der mRNA ist mit diesem Verfahren nicht möglich und erscheint aufgrund der Schwankungsbreite auch nicht sinnvoll.

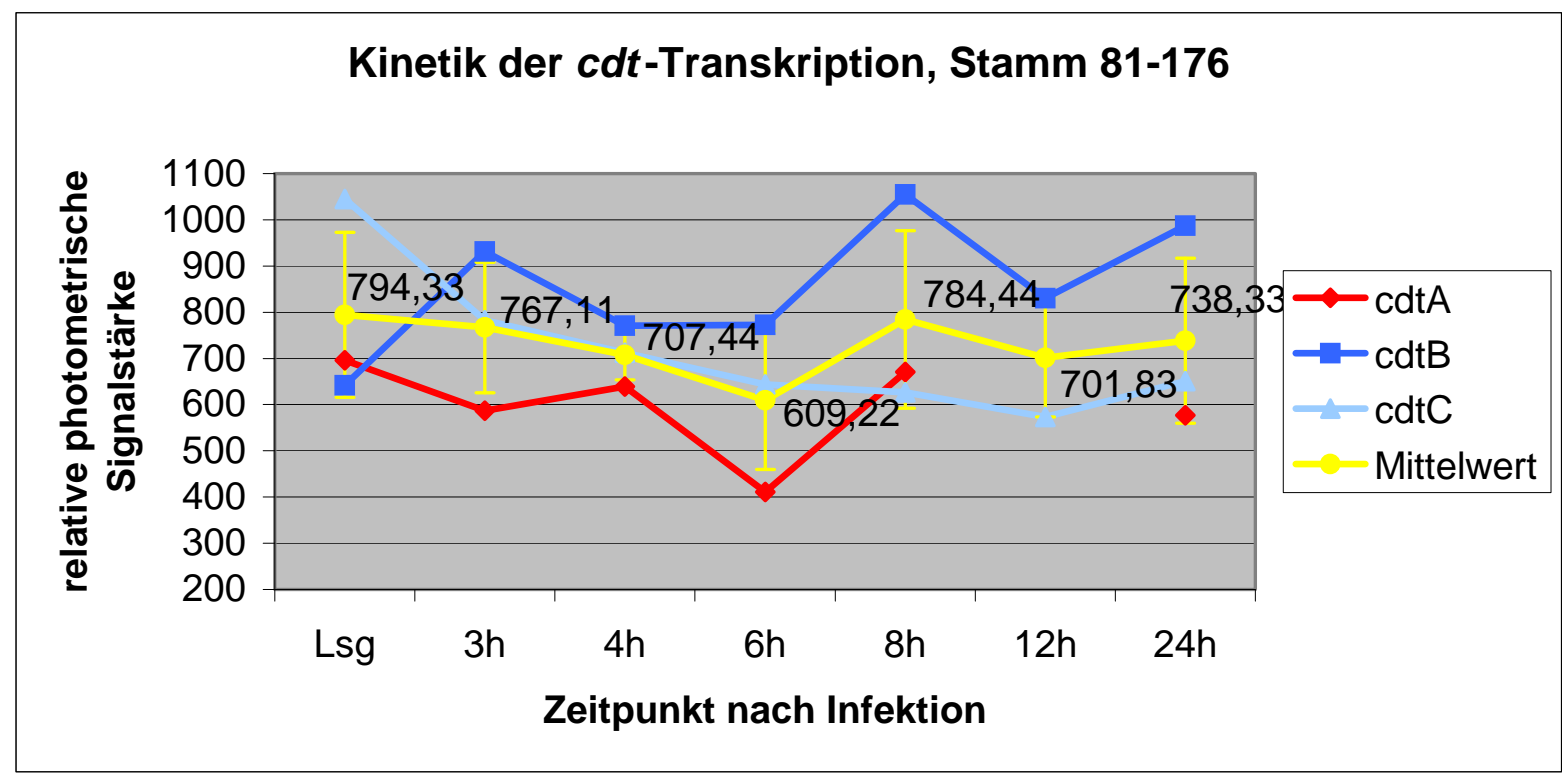

Abbildung 16: Vergleich der $c d t$-Transkription ( $c d t A, c d t B, c d t C$ und Mittelwerte) des Referenzstammes 81-176 nach Infektion in Caco-2-Zellen, photometrische Bestimmung der Bandenstärke nach konventioneller One-Step-RT-PCR und Auftragung auf Agarosegel; Messpunkte: Infektionslösung, 3h, 4h, 6h, 8h, 12h und $24 \mathrm{~h}$ nach Infektion, Crossingpoint-Zyklenzahlen eines repräsentativen Experimentes 


\subsection{Molekularbiologie - Vergleich der cdt-Transkription in verschiedenen Wirtszellen}

Im letzten Experiment wurde die cdT-Transkription von Campylobacter jejuni 24h nach Infektion von primären Hühnerdarmzellen, Caco-2-Zellen sowie unter Inkubation in zellfreiem Medium verglichen. Hierfür wurde stellvertretend die Transkription von $c d t A$ und cdtB des Stamms av-518 bestimmt. Durch die polycistronische Anordnung der drei Toxingene und Transkription in dieselbe mRNA (wie beschrieben), wären für alle drei Gene vergleichbare und zueinander proportionale Resultate $\mathrm{zu}$ erwarten, welche sich trotz einiger methodischer Nachweisschwierigkeiten, v.a. für $c d t C$, tendenziell auch zeigten.

Die Infektion von Caco-2-Zellen ergab im Vergleich zur Infektion von Hühnerdarmzellen und zur Inkubation in zellfreiem Medium leicht verringerte Zyklenzahlen, die jedoch nicht signifikant verringert waren und in Anbetracht des späten Nachweises bei hohen Zyklenzahlen auch auf die vorausgegangene Normierung auf 16S-rRNA zurückgeführt werden könnten (Tab.6). Es zeigte sich daher auch in diesen Experimenten, dass die cdtTranskription durch Campylobacter jejuni in Abhängigkeit von Infektion der Wirtszelle oder Inkubation in Kultur keiner großen Schwankungsbreite unterliegt oder - zumindest in dem von uns gewählten experimentellen Ansatz - nicht durch externe Signale beeinflusst zu werden scheint.

Tabelle 6: $c d t$-Transkription ( $c d t A$ und $c d t B$ ) des hochinvasiven Stammes av-518; Vergleich 24h nach Infektion von Caco-2-Zellen; Hühnerdarmzellen und Inkubation in Medium; Ergebnisse zweier unabhängiger Experimente; rot markierte Werte unter Vorbehalt, da Produkt aufgrund mehrere Peaks in der Schmelzpunktanalyse voraussichtlich nicht rein und daher nicht voll spezifisch

\begin{tabular}{|c|c|c|c|c|}
\hline $\begin{array}{c}\text { Stamm, } \\
\text { Kulturbedingung }\end{array}$ & \multicolumn{2}{|c|}{$\begin{array}{c}\text { Crossing points } \\
\text { cdtt }\end{array}$} & \multicolumn{2}{c|}{$\begin{array}{c}\text { Crossing points } \\
\text { cdtB }\end{array}$} \\
\hline $\begin{array}{c}\text { av-518, } \\
\text { Medium }\end{array}$ & 1. Versuch & 2. Versuch & 1. Versuch & 2. Versuch \\
\hline $\begin{array}{c}\text { av-518, } \\
\text { Caco-2 }\end{array}$ & 32,95 & 35,04 & $\begin{array}{c}\text { Kein } \\
\text { Nachweis }\end{array}$ & 31,16 \\
\hline $\begin{array}{c}\text { av-518, } \\
\text { Hühnerdarmzellen }\end{array}$ & 31,3 & 33,8 & 33,46 & $\begin{array}{c}31,58 \\
(2 \text { Peaks })\end{array}$ \\
\hline
\end{tabular}




\section{Diskussion}

Bei den meisten Spezies, wie auch dem Huhn als postulierter Hauptinfektionsquelle des Menschen, tritt kommensale Kolonisation durch Campylobacter jejuni, jedoch keine Inflammation oder gar blutiger Durchfall auf. Dem Cytolethal distending toxin $(\mathrm{Cdt})$ wird ein großer Beitrag zu dieser Pathogenese durch Induktion von Apoptose in exponierten Zellpopulationen zugeschrieben. Die generelle Zielsetzung dieser Arbeit war es folglich herauszufinden, ob eine Anpassung von Campylobacter jejuni im eigentlichen Wirt bezüglich Apoptose-Induktion durch Cdt existiert, beziehungsweise ob die Herkunft von Campylobacter-Wildtypisolaten oder die Art der befallenen Wirtszelle einen Einfluss auf die bakterielle Toxin-Transkription und die daraus resultierenden zytotoxischen Effekte haben. Lebendige bakterielle Isolate sowie bakterielle Lysate unterschiedlicher Herkunft wurden daher mit verschiedenen Methoden in ihrer Fähigkeit untersucht gegenüber humanen und aviären epithelialen Zellen Apoptosevorgänge zu induzieren. Des Weiteren wurde in diesem Kontext die bakterielle cdt-Transkription in Abhängigkeit von den genannten Konditionen bestimmt.

Die Entscheidung für Caco-2 als Beispielzelllinie für das menschliche Darmepithel erfolgte aufgrund der relativ einfachen Zellkulturhandhabung und der breiten Verwendung für Experimente mit Campylobacter jejuni in der Fachliteratur (z.B. Everest et al. 1992). Im Vergleich zu anderen humanen epithelialen Zelllinien zeigt Campylobacter jejuni gegenüber Caco-2-Zellen eine höhere Kapazität zur Adhäsion und Invasion als etwa gegenüber HeLaoder Vero-Zellen (Coote et al. 2007). Ein Versuchsansatz mit primären humanen Enterozyten, z.B. aus klinischen Biopsien, hätte das humane intestinale Milieu sicherlich präziser widergespiegelt. Die ethischen und praktischen Schwierigkeiten eines solchen Experimentaldesigns und die in den nachfolgenden Versuchen mit primären intestinalen Hühnerdarmzellen (primary intestinal chicken cells, PIC) zusätzlich aufgetretenen Handhabungsprobleme lassen die getroffene Wahl aber richtig erscheinen. Wie die nachfolgenden Experimente hinsichtlich des Invasionsverhaltens und auch die Vergleichsliteratur (Byrne et al. 2007) zeigen, besitzt Campylobacter jejuni gegenüber Caco2-Zellen zudem ein ähnliches Invasionsvermögen wie gegenüber primären Epithelzellen. Weiterhin stellt die Verwendung einer immortalisierten Zelllinie in vergleichenden Experimenten zur Apoptose-Induktion naturgemäß einen schwerkalkulierbaren Einflussfaktor dar. Tatsächlich erweisen sich die primären Hühnerdarmzellen demgegenüber schon in der 
alläglichen Handhabung als äußerst empfindlich und produzieren unter Zellkulturbedingungen sowie konsekutiv nach Inkubation mit bakteriellem (Toxin-)Lysat geringradig höhere relative Caspase-3-Spiegel und zeigen niedrigere relative Zellzahlen im Vergleich zur unbehandelten Negativkontrolle. Es erscheint jedoch sehr wahrscheinlich, dass diese geringgradigen Unterschiede durch die immortalisierenden Eigenschaften der Caco-2Krebszelllinie bedingt sind und keine größere speziesspezifische Cdt-Empfindlichkeit der Hühnerdarmzellen wiedergeben, zumal ein solcher Effekt der in vivo beobachteten klinischen Unempfindlichkeit von Geflügel gegenüber einer Kolonisation mit Campylobacter jejuni widersprechen würde. Vielmehr scheint es nach den vorliegenden Ergebnissen, dass beide Zellpopulationen (human und aviär) unter Zellkulturbedingungen eine vergleichbare Empfindlichkeit gegenüber einer Inkubation mit Cdt besitzen.

Um die Vergleichbarkeit des Effekts von Infektion und Toxinwirkung auf Caspase-3Aktivität und Apoptosinduktion durch die $\mathrm{zu}$ untersuchenden Campylobacter-Isolate unterschiedlicher Herkunft gewährleisten zu können, war es initial notwendig, die Fähigkeiten zur Invasion gegenüber den verwendeten epithelialen Zellen zu bestimmen. Dies erscheint umso mehr sinnvoll, da auch schon in früheren Experimenten eine klare Korrelation zwischen Zellinvasion und Zytotoxizität nachgewiesen wurde (Coote et al. 2007) und die Bedeutung eines hohen Invasionsvermögens als wichtiger bakterieller Pathogenitätsfaktor allein schon vom logischen Verständnis auf der Hand zu liegen scheint.

Die beiden gewählten Methoden zur Bestimmung des Invasionsvermögens ergaben hierbei valide und untereinander tendenziell vergleichbare Ergebnisse. Jedoch lieferte das IFTVerfahren trotz des größeren Arbeitsaufwandes, welcher es im Vergleich zum Invasionstest für großangelegte Screeningtests ungeeignet erscheinen lässt, wesentlich reproduzierbarere und mit einer geringeren Schwankungsbreite behaftete Resultate. Dies wundert nicht, da es sich hierbei um eine direkte Nachweismethode ohne die bereits beschriebenen, potenziell fehlerbehafteten Zwischenschritte des Invasivitätstests handelt. Weiterhin zeigte sich, dass das Invasionsvermögen der jeweiligen Campylobacte-jejuni-Isolate, zumindest unter in-vitro Bedingungen, keine signifikanten Unterschiede im Hinblick auf die verwendeten Wirtszellen (human versus aviär) aufweist und somit auf den ersten Blick ebenfalls nicht für die ausgeprägte klinischen Symptomatik einer Infektion beim Menschen verantwortlich zu sein scheint. Dieses deckt sich mit Experimenten von Byrne et al. aus dem Jahre 2007, in denen dieses Ergebnis ebenfalls für bioptisch aus menschlichem und Hühnerdarm gewonnenen und 
kultivierten primären intestinalen Zellen gezeigt werden konnte. Frühere Experimente von Konkel et al. aus dem Jahr 1992 hatten hingegen nahegelegt, dass Campylobacter jejuni zwar an Zellen menschlicher und nicht-menschlicher Herkunft in vergleichbarem Maße bindet, jedoch viel effizienter in Zellen menschlicher Herkunft internalisiert wird (Konkel et al. 1992). Hänel und Kollegen haben darüber hinaus gezeigt, dass auch das in-vitro Invasionsverhalten gegenüber Caco-2-Zellen mit der Kolonisationsfähigkeit des Hühnerdarmes unter in-vivo-Bedingungen korreliert (Hänel et al. 2004).

Die einzelnen untersuchten Stämme zeigten weiterhin eine große Schwankungsbreite hinsichtlich ihrer individuellen Invasionsfähigkeit. Der aviäre Stamm av-518 erwies sich mit einer Effizienz von über 2\% als mindestens eine log-Stufe invasiver als die am geringsten invasiven Stämme hu-1, av-245 und B/IV/509 (je nach gewählter Methode) und ist damit auch im Vergleich zu anderen in der Fachliteratur beschriebenen Isolaten als hochinvasiv anzusehen (vgl. Hänel et al. 2004).

Schon mehrere Autoren hatten zuvor gezeigt, dass teilweise große interindividuelle Unterschiede von mehr als 2 log-Stufen bezüglich Invasionsvermögen zwischen verschiedenen Wildtypstämmen von Campylobacter jejuni bestehen (Konkel et al 1992, Everest et al. 1992, Hänel et al. 2004, Byrne et al. 2007). Interessanterweise hatten auch schon andere Autoren zuvor (wie hier angewendet) eine generelle Einteilung von Campylobacter-Wildtypisolaten in drei Kohorten von abgestufter Invasions- bzw. Kolonisationsfahigkeit unter in-vitro- und in-vivo-Bedingungen getroffen (Korolik et al. 1998, Hänel et al. 2004).

Es scheint von Bedeutung zu sein, dass die Herkunft der Isolate keine offensichtlichen Rückschlüsse auf deren Invasionsvermögen zulässt, obwohl Fauchere et al. schon 1986 in Zellkulturexperimenten eine generell grössere Invasivität von klinischen als von nichtklinischen Campylobacter-Isolaten postuliert hatten (siehe ebenfalls Everest et al. 1992). Das hier untersuchte Bakterienkollektiv ist zwar sicherlich zu klein, um diesbezüglich eine valide Aussage treffen zu können. Jedoch zeigte sich auch in einer Untersuchung von Van Deun et al. aus dem Jahr 2007, in welcher 20 Hühnerisolate und 24 menschliche Isolate verschiedenster Herkunft und großer genetischer Variabilität untersucht wurden, kein signifikanter Unterschied im durchschnittlichen Invasionsvermögen zwischen den beiden Gruppen. Weiterhin traten ebenfalls starke interindividuelle Unterschiede zwischen den 
einzelnen Stämmen auf. Unter den humanen Isolaten fanden sich mehr hochgradig-invasive Stämme als unter den aviären (jedoch nicht signifikant). Alle Isolate, bis auf jeweils eines aus beiden Kollektiven, waren invasiv (Van Deun et al. 2007). Auch Coote und Kollegen konnten keine signifikanten Differenzen zwischen menschlichen, bovinen und aviären Isolaten bezüglich Adhärenz und Invasion gegenüber verschiedenen Zelllinien nachweisen (Coote et al. 2007).

Nach Bestimmung dieser ausgeprägten Differenzen im Invasionsvermögen der untersuchten Isolate erscheinen die Schwankungen der Caspase-3-Aktivitäten nach Infektion von Caco-2Zellen plausibel. Diese korrelierten v.a. nach $48 \mathrm{~h}$ bei allen Cdt-produzierenden Isolaten mit den in den Vorversuchen bestimmten Invasionsfähigkeiten, wenn auch nicht in proportionalem Maße. Ein Zusammenhang von Invasionsfähigkeit und Toxineffekt konnte hiermit zwar hinlänglich nachgewiesen werden, gleichzeitig jedoch erschwert dies die experimentelle Bestimmung eines direkten Zusammenhangs von stammspezifischer cdtTranskriptionsstärke und dem daraus resultierenden Grad der Apoptose-Induktion.

Um dies zu umgehen, wurde in den nachfolgenden Versuchansätzen daher die Caspase-3Aktivität der Zellen nach Inkubation mit äquivalenten Mengen bakteriellen Cdt-haltigen Lysats (Van Deun et al. 2007) der einzelnen Isolate bestimmt. Hiermit lässt sich zwar der aktuelle Toxingehalt der verschiedenen Isolate unter Inkubationsbedingungen vergleichen, jedoch erfolgt der gemessene Wirkeffekt durch das extrazellulär vorliegende Toxin und erlaubt keine Rückschlüsse auf eine eventuelle Adaptation der Toxinproduktion der normalerweise intrazellulär vorliegenden Bakterien durch eine spezifische Wechselwirkung mit der Wirtszelle oder geänderte Umweltbedingungen. Untersucht wurden jeweils (Toxin-) Lysate eines hoch- und eines mäßiggradig invasiven Stammes menschlicher und aviärer Herkunft sowie des Cdt-negativen Stammes B/IV/509. Die Stufe der verwendeten Lysatverdünnungen wurde in Vorversuchen bestimmt, in welchen durch Caspase-3-Messung $\mathrm{zu}$ verschiedenen Zeitpunkten in einem praktikablen Zeitfenster (unter anderem definiert durch Wachstums- und Absterberate der unbehandelten Negativkontrolle) ein signifikanter Toxin-Effekt nachweisbar war.

Unter den gegebenen Bedingungen zeigten sich sowohl gegenüber Caco-2-Zellen als auch gegenüber primären Hühnerdarmzellen zu den Messzeitpunkten keine Unterschiede in der Toxinwirkung von äquivalenten Mengen an Campylobacter-Lysat unterschiedlicher Herkunft (human versus aviär). Die vier Cdt-produzierenden Isolate induzierten vergleichbare Caspase- 
3-Aktivitäten und Reduktionen der relativen Zellzahlen. Lysat des Cdt-negativen Stammes B/IV/509 zeigte hingegen gegenüber beiden Zelltypen nur geringgradige Varianzen zur unbehandelten Negativkontrolle bezüglich einer Beeinflussung von Caspase-3-Aktivität und Zellzahlen. Es liegt daher nahe zu schlussfolgern, dass es sich bei Cdt um die wirksame, apoptose-induzierende Komponente im Campylobacter-Lysat handelt.

Die große Übereinstimmung der gemessenen, durch Lysat der vier Cdt-produzierenden Isolate induzierten, Caspase-3-Aktivitäten überrascht, zumal in der Literatur regelmäßig zum Teil sehr stark variierende Unterschiede beschrieben werden (siehe unten). Neben der daraus resultierenden Annahme einer nahezu identischen präformierten Cdt-Produktion in den vier verwendeten Stämmen ist es auch durchaus möglich, dass es durch den eingangs beschriebenen Wirkmechanismus des Cdt, welcher eine lange Latenzzeit zwischen Toxinexposition und Eintritt der Caspasekaskade aufweist, zu einer Verfälschung der Messergebnisse gekommen sein kann. Die Blockade des Zellzyklus' kann mehrere Stunden bis Tage andauern, wohingegen die Caspasekaskade, sobald diese erst einmal angestoßen wurde, in einem wesentlich kürzeren Zeitintervall abläuft. Andere Autoren quantifizierten bei ihren Experimenten mit $C d t$ daher zum Beispiel den Anteil der in der $\mathrm{G}_{2}$-Phase blockierten Zellen mittels Durchflusszytometrie (Van Deun et al. 2007) und konnten somit frühere Messpunkte nach Exposition wählen. Auch lässt sich nicht sicher ausschließen, dass es bei den verwendeten Lysat-Konzentrationen aufgrund supramaximaler Toxin-Spiegel in den Proben zu einem Übersättigungseffekt gekommen ist, infolgedessen alle Zellen im Zellzyklus blockiert wurden und deshalb konsekutiv (mit Ausnahme zum Cdt-negativen Stamm B/IV/509) keine Unterschiede in Caspase-3-Aktivität zwischen den einzelnen bakteriellen Lysaten gemessen werden konnten. Die effektiven Toxinkonzentrationen konnten mit den uns zur Verfügung stehenden Methoden leider nicht direkt bestimmt werden. Allerdings zeigt Cdt, zumindest gegenüber menschlichen T-Lymphozyten, eine sowohl dosis- wie auch zeitabhängige Toxinwirkung bis hin zu sehr hohen Toxinkonzentrationen von 50ng/ml (Shenker et al. 2006), welche in unseren Experimenten wohl nicht erreicht wurden. Im Folgenden zeigte sich auch im Vergleich der $c d t$-Transkription unter Inkubationsbedingungen mittels RT-PCR (siehe unten) kein signifikanter Unterschied zwischen den vier untersuchten Isolaten.

Bang und Kollegen verwendeten in Versuchen mit Verozellen geringere CampylobacterLysat-Titer, größtenteils in Verdünnungsstufen zwischen 1:10 und 1:100, jedoch über längere 
Inkubationszeiträume. Dieses Verfahren quantifiziert den Toxineffekt mittels PhasenKontrast-Mikroskopie durch Veränderungen in der Zellmorphologie, welche durch den Arrest in der $\mathrm{G}_{2}$-Phase auftreten, in Abhängigkeit von verschiedenen Titerstufen eines bakteriellen Zelllysats. Allerdings variierten auch hier die Titerstufen bei 99 von 101 untersuchten Isolaten nur um den Faktor 4 (Bang et al. 2001). Zudem erlauben die so beobachteten Morphologieveränderungen wiederum nur Rückschlüsse auf den Stopp des Zellzyklus mit Zellschwellung, jedoch nicht den zweizeitigen Eintritt der Apoptose durch Initialisierung der Caspasekaskade. Ähnlich unseren Ergebnissen lieferten Untersuchungen von AbuOun und Kollegen mit 24 Campylobacter-Stämmen verschiedenster Herkunft gleichfalls nur eine geringe Varianz der Lysat-Titer. Auch trat hierbei ebenfalls keine Korrelation mit der Herkunft der Isolate auf (AbuOun et al. 2005).

In den aktuellsten vergleichenden Experimenten dieser Art verwendeten Van Deun und Kollegen im Jahr 2007 Lysate von 20 aviären und 24 humanen Campylobacter-Isolaten von großer genetischer Variabilität (Vergleich der PFGE-Muster). Die menschliche Isolate blockierten hierbei im Durchschnitt mehr Zellen in der Zellzyklusprogression $(55.3 \%$ +/$3.6 \%)$ als die Hühnerisolate $(43.5 \%+/-4.4 \%)(\mathrm{P}=0.041)$. Für die Extremwerte konnten jedoch keine Unterschiede in den Proportionen zwischen menschlichen und aviären Isolaten gefunden werden. Weiterhin implizierten die Daten über Herkunft der Isolate einen Zusammenhang zwischen Cdt-Produktion und klinischer Ausprägung der Erkrankung. Allerdings waren zwei der klinischen Isolate sogar Cdt-negativ (Van Deun et al. 2007). Cdt scheint also nicht die einzige Determinante für den Grad der klinischen Ausprägung beim Patienten zu sein, obwohl sich auch in unseren Experimenten unter in-vitro Bedingungen weder für Inkubation mit Lysat des Cdt-negativen Stammes B/IV/509 noch nach Infektion mit diesem Stamm ein signifikanter Effekt auf Mitose- oder Apoptose-Induktion nachweisen liess. Auch fanden Van Deun und Kollegen keinen statistisch signifikanten Unterschied zwischen Hühnerisolaten und menschlichen klinischen Isolaten in ihrer Fähigkeit durch T84 Zellen eine Interleukin-8-Freisetzung zu induzieren (Van Deun et al. 2007). Cdt-Produktion hatte sich in vorherigen Experimenten unter in-vitro-Bedingungen als einer der hauptverantwortlichen Faktoren für die Interleukin-8-Freisetzung durch infizierte intestinale Zellen und damit auch für die inflammatorische Reaktion der Wirts-Mukosa gezeigt (Hickey et al. 2000). 
In einem etwas weiter angelegten Versuchsansatz zum Vergleich der Virulenz von Campylobacter-jejuni - Isolaten unter in-vitro-Bedingungen untersuchten Coote und Kollegen schließlich 40 Isolate aus ebenfalls unterschiedlichsten Quellen bezüglich ihrer hämolytischen Aktivität gegenüber Kaninchenerythrozyten sowie ihren zytotoxischen Aktivitäten gegenüber einigen weiteren Zelllinien (inklusive Caco-2). Trotz uneinheitlicher Ergebnisse mit einer weiten Variationsbreite zeigte sich jedoch auch hier für alle untersuchten Stämme in keinem Versuchsansatz eine klare Beziehung zwischen Quelle der Isolierung und Toxizität (Coote et al. 2007, siehe ebenfalls Nadeau et al. 2003).

Das im Anschluss verwendete IFT-Verfahren zur direkten Bestimmung des Anteils apoptotischer Zellen nach Infektion schließt ein noch größeres Zeitintervall zwischen Toxinexposition und möglicher Beobachtung eines Effektes ein und ist infolgedessen ebenfalls nicht unkritisch $\mathrm{zu}$ sehen. Es erlaubt andererseits jedoch eine direkte Differenzierung bezüglich der Auswirkung einer Infektion mit lebendigen Bakterien bzw. Inkubation mit Lysat auf Induktion von Apoptose bzw. Unterbrechung der Mitose der einzelnen betroffenen Zelle.

Wie aus den bisherigen Beobachtungen nicht anders zu erwarten, zeigten sich die primären Hühnerdarmzellen im Vergleich zu den Caco-2-Zellen wiederum etwas empfindlicher gegenüber einer Toxinexposition infolge Infektion oder Inkubation mit Lysat. Weiterhin bestätigte sich erneut der direkte Zusammenhang zwischen hohem Invasionsvermögen eines Isolates und Auswirkung auf Mitose- und Apoptose-Rate. Lysate der beiden untersuchten Cdt-produzierenden Stämme hu-3 und av-518 zeigten gegenüber beiden Zellpopulationen vergleichbare Effekte. Hingegen bewirkte weder die Infektion noch die Inkubation mit dem Cdt-negativen Stamm B/IV/509 einen signifikanten Effekt hinsichtlich einer Veränderung der Apoptose- oder Mitose-Raten im Vergleich zur unbehandelten Negativkontrolle. Dies deckt sich mit Beobachtungen von Jain und Kollegen, in welchen in Epithelzellen nach Inkubation mit Lysat von fünf Cdt-positiven und fünf Cdt-negativen klinischen Campylobacter-Isolaten durch letztere Gruppe in keinem Fall weder die klassische Zellschwellung, noch Zellzyklusarrest oder Apoptose (bestimmt durch DNA-Fragmentation) hervorgerufen werden konnte (Jain et al. 2009). Auch für die einzelne untersuchte infizierte Zelle konnte mit den Cdt-produzierenden Stämmen hu-3 und av-518 ein direkter Zusammenhang zwischen Infektion und nachfolgender Unterbrechung des Mitosezyklus mit konsekutiver Induktion der 
Apoptose beobachtet werden. Nach Infektion mit dem Cdt-negativen Stamm B/IV/509 zeigte sich in den befallenen Zellen hingegen kein zu beobachtender Effekt.

Nachdem sich nach den bisherigen Resultaten für die untersuchten Cdt-produzierenden Bakterien-Isolate keine sicheren Hinweise auf stammspezifisch-variierende Toxinproduktion fanden und aufgrund der unterschiedlichen Invasionsfähigkeiten ein direkter in-vivoVergleich der induzierten Caspase-3-Spiegel nicht möglich war, sollte nun in ergänzenden Experimenten die Fragestellung der cdt-Transkription mittels RT-PCR weiter behandelt werden. Weiterhin sollte geklärt werden, ob die Expression des bakteriellen Cdt vom intrazellulären Milieu der jeweils benutzten Wirtszelle beeinflusst wird.

Generell ist noch nicht geklärt, ob überhaupt Umweltbedingungen oder Einflussfaktoren existieren, unter denen Campylobacter jejuni die Transkription von Cdt verändert. So konnten in frühen Untersuchungen mit dem häufig verwendeten Referenzstamm Campylobacter jejuni 81-176 keine Auswirkungen von Veränderungen in Eisengehalt und Temperatur des Kulturmediums oder der Wachstumsphase der Bakterien auf die Cdt-Produktion festgestellt werden (Pickett 2000). Im Allgemeinen benötigt die Initiierung der Transkription eines Genes oder Operons durch das eubakterielle RNA-Polymerase-Holoenzym spezifische Co-Faktoren, sogenannte Sigmafaktoren. Zusammen erkennen und binden diese an Promotorsequenzen stromaufwärts von einer abzulesenden Gensequenz. Die Stärke eines Promotors wird dadurch bestimmt, wie genau er eine bestimmte „Konsens-Sequenz“ widerspiegelt und welche Position er in einem definiertem Bereich vor dem transkriptionellen Startpunkt einnimmt. Im Gegensatz zu Bacillus subtilis mit 14 Sigmafaktorgenen und Escherichia coli mit immerhin noch sieben, wurden im Genom von Campylobacter jejuni bisher hingegen nur drei Sigmafaktorgene $\left(\sigma^{28}, \sigma^{54}\right.$ und $\left.\sigma^{70}\right)$ entdeckt (Parkhill et al. 2000). Wie bereits eingangs erwähnt, konnte im Bereich $81 \mathrm{bp}$ stromaufwärts des cdtA-Startcodons eine potentielle Promotorsequenz mit Homologien zur „Konsens-Sequenz“ des $\sigma^{70}$ Promotors von Campylobacter jejuni gefunden werden. Ob und wie die Erkennung und Bindung des $\sigma^{70}$ Promotors von Campylobacter jejuni reguliert wird, ist derzeit jedoch noch unklar.

Obwohl Campylobacter jejuni in einer breiten Spanne von ökologischen Nischen überleben kann, scheint seine Fähigkeit zur Regulation der Gen-Transkription als Antwort auf umweltbedingte Stressoren im Vergleich mit anderen Bakterienspezies, wie zum Beispiel E. coli und B. subtilis, generell sehr limitiert. Campylobacter jejuni scheint darüber hinaus 
ebenfalls keine „traditionellen“ Hitzeschock- oder Stationärphase-Sigmafaktorgene zu besitzen (Petersen et al. 2003), welche bei anderen Keimen eine wichtige Rolle in der flexiblen Anpassung an wechselnde Umweltbedingungen spielen. Verschiedene Bakterienspezies unterscheiden sich sehr stark in ihren Antwortmöglichkeiten auf umweltbedingten Stress, doch alle haben zumindest eine gewisse Kapazität zur Überwachung von Veränderungen der Umweltbedingungen, welche eine adaptive Antwort erfordern um ein Überleben zu ermöglichen (Elvers und Park 2002). So wurde für Campylobacter jejuni zuletzt mittels Microarray-Analysen ein Genäquivalent (spoT) zur bakteriellen stringent response im Rahmen der Infektion von epithelialen Zellen postuliert, welches als globale Stressantwort durch Genregulation Einfluss auf Adhärenz, Invasion und intrazelluläres Wachstum sowie Langzeitüberleben und Antibiotikaresistenz ausüben soll. Ein Zusammenhang mit der CdtRegulation wurde hierfür jedoch nicht beschrieben (Gaynor et al. 2005).

In dieser Arbeit wurde untersucht, ob die verwendete Art der Wirtszelle einen Einfluss auf die $c d t$-Transkription hat. Diese Fragestellung wurde auf die vier verwendeten Cdtproduzierenden Stämme fokussiert. Es konnte gezeigt werden, dass die Cdt-spezifische RNAKonzentration des Referenzstammes 81-176 nach Infektion nur unwesentlich abfällt und innerhalb weniger Stunden wieder auf das Niveau der unter zellfreien Inkubationsbedingungen vergleichend mitgeführten Negativkontrolle ansteigt. Dieser allenfalls dezente Effekt auf die cdt-Transkription kann aber keinesfalls als signifikant bewertet werden. Eine postinvasive Down-Regulation der Toxinproduktion bzw. eine generelle Anpassung der globalen Proteinproduktion zugunsten anderer adaptiver Vorgänge mit im Verlauf nachfolgender Rückregulierung auf das Ausgangsniveau scheint somit zwar denkbar, aber unwahrscheinlich.

Weiterhin scheint sich die cdt-Transkription zwischen verschiedenen Stämmen unter vergleichbaren Kulturbedingungen nicht $\mathrm{zu}$ unterscheiden, was Carrillo und Kollegen ebenfalls mittels Microarray-Analysen nachweisen konnten (Carrillo et al. 2004). Dies deckt sich insofern mit unseren Ergebnissen, als dass auch die beiden humanen Isolate hu-1 und hu-3 unter Inkubationsbedingungen im Vergleich zu den beiden aviären Isolaten av-245 und av-518 nur geringfügig niedrigere Reaktionszyklen, d.h. geringfügig größere cdt-RNAKonzentrationen, zeigten. Der gemessene Unterschied kann aufgrund der im Ergebnisteil genannten methodischen Einschränkungen nicht als signifikant bewertet werden. 
Auch im Vergleich der cdt-Transkription unter verschiedenen Wirtszellbedingungen nach Infektion humaner und aviärer Zellen bzw. zellfreien Inkubationsbedingungen konnten zum Zeitpunkt 24h nach Infektion keine signifikanten Unterschiede zwischen den verwendeten Proben festgestellt werden.

Zusammenfassend konnten wir daher die in der Literatur beschriebene Variabilität der Toxinproduktion verschiedener Isolate mit den angewandten Methoden der cdtTranskriptbestimmmung nicht nachvollziehen. Die Frage, ob die Aktivität definierter Promotorsequenzen bzw. Sigmafaktoren unter verschiedenen Isolaten oder bei Infektion verschiedener Wirtszellen variiert oder ob posttranskriptionelle und posttranslationelle Faktoren für die beobachteten Unterschiede verantwortlich sind, bedarf weiterer Untersuchungen. Es ist somit folglich schwierig, über wirts- oder zell-spezifische Auswirkungen auf die bakterielle Toxinproduktion und eine möglicherweise daraus resultierende veränderte Klinik zwischen der Infektion bei Huhn und Mensch zu spekulieren (Eyigor et al. 1999).

Wie bereits erläutert, zeigt exponiertes Geflügel bei natürlich erworbener Besiedlung durch Campylobacter jejuni im Gegensatz zur akuten Enterokolitis des Menschen trotz prolongierter Kolonisation keine Hinweise auf pathologische Veränderungen im Darm. In in-vivoExperimenten treten nach intestinaler Kolonisierung von Vögeln jenseits des Jungtieralters keine Anzeichen für intestinale Inflammation, zelluläre Adhäsion oder Invasion in das Darmepithel auf (Meinersmann et al. 1991). In vitro zeigte sich jedoch in unseren Untersuchungen für primäre Hühnerdarmepithelien und menschliche Darmzellen eine vergleichbare Adhäsion und Invasion von Campylobacter jejuni, sowie eine ebenfalls vergleichbare Empfindlichkeit der Zellen gegenüber Cdt. Welche weiteren Faktoren könnten also für die von anderen Arbeitsgruppen zum Teil beschriebenen Unterschiede verantwortlich sein?

Erwähnt sei in diesem Zusammenhang die umweltbedingte Regulation des Flagellarkomplexes von Campylobacter jejuni als weiterem wichtigen Virulenzfaktor. Die Transkription der beiden Haupt-Flagellingene flaA und flaB wird durch die beiden anderen bisher bekannten Promotorgene $\left(\sigma^{28}\right.$ und $\left.\sigma^{54}\right)$ von Campylobacter jejuni gesteuert (Bereswill und Kist 2002). Im Falle von flaB konnte klar gezeigt werden, dass eine Modulation von physikalischen Umweltbedingungen wie $\mathrm{pH}-\mathrm{Wert}$, Wachstumstemperatur und Viskosität 
sowie der Konzentration von bestimmten anorganischen Salzen und divalenten Kationen $\left(\mathrm{Zn}^{2+}\right.$ und $\left.\mathrm{Mg}^{2+}\right)$ im Medium regulativen Einfluss auf dessen Expression mit konsekutiven Auswirkungen auf Motilität und Bewegungsverhalten und somit auch Adhäsions- und Invasionsfähigkeit des Keimes ausübt (Alm et al. 1993, Szymanski et al 1995). Den stärksten positiv-regulativen Einfluss auf die flaB-Promotoraktivität übte hierbei ein Anheben der Wachstumstemperatur von $37^{\circ} \mathrm{C}$ auf $42^{\circ} \mathrm{C}$ aus (Alm et al. 1993). Die Untersucher stellten die Hypothese auf, dass die Regulation des Flagellarapparates ein wichtiger Faktor für die Kolonisation von anderen biologischen Nischen mit höherer Körpertemperatur, wie z.B. dem Intestinaltrakt von Hunden und Vögeln, sei und damit einen Beitrag zum unterschiedlichen klinischen Verhalten gegenüber diesen Organismen leistet (Szymanski et al 1995). Dies deckt sich ebenfalls mit den Vermutungen von On und Kollegen, dass bestimmte fla-GenKonfigurationen am besten für die Kolonisation von Geflügel geeignet seien, da in ihren Untersuchungen eine genetische Divergenz dieser Gene nur unter Geflügel-Isolaten aufgetreten war (On et al. 2006).

Auch andere Autoren sehen die teilweise signifikant differierenden physikalischen Umweltbedingungen zwischen aviärem und humanem Darm als mitverantwortlich für die größere Empfindlichkeit des menschlichen Organismus gegenüber Campylobacter jejuni an. Khanna et al. haben gezeigt, dass sowohl Wachstumsrate als auch chemotaktische Beweglichkeit (entgegen obiger Resultate) verschiedener Campylobacter-Isolate bei $37^{\circ} \mathrm{C}$ größer sind als bei $42^{\circ} \mathrm{C}$ und somit die menschliche Körpertemperatur gegenüber der aviären bessere Inkubationsbedingungen bietet (Khanna et al. 2006). Eine höhere Populationsdichte durch gesteigertes Wachstum könnte u. U. auch regulative Auswirkungen auf die Expression von Cdt als potenziellem Virulenzfaktor haben.

Die Ergebnisse anderer Studien lassen jedoch vermuten, dass die Temperaturdifferenz zwischen menschlichem und aviärem Organismus keinen signifikanten Einfluss auf die Virulenz von Campylobacter jejuni ausübt (Byrne et al. 2007). In Untersuchungen mittels RNA-Microarrays konnte gezeigt werden, dass sich nach Anheben der Inkubationstemperatur von $37^{\circ} \mathrm{C}$ auf $42^{\circ} \mathrm{C}$ das Transkriptom von Campylobacter jejuni nur transient verändert und nur eine kleine Subpopulation von Genen dauerhaft verändert exprimiert bleibt (Stintzi 2002). Interessanterweise betrifft dies vor allem Gene, die in Membranstrukturveränderungen involviert sind. Dies könnte auf einen modifizierten zellulären Protein- und Glycosylmembranaufbau hinweisen, der es dem Keim ermöglicht, verschiedenste ökologische 
Nischen, wie z. B. den Intestinaltrakt von Vögeln und Säugetieren, zu kolonisieren oder durch Veränderungen der äußeren Proteinschicht dem Wirtsimmunsystem zu entgehen (Stintzi 2002).

Auch dem Einfluss von unter in-vivo-Bedingungen durch die Enterozyten in das Darmlumen exkretierten, spezifischen Substanzen wird ein Beitrag an der selektiven Unempfindlichkeit von Hühnern zugeschrieben. So reduzieren sich die Infektionsraten primärer menschlicher Darmepithelzellen nach Inkubation unter Zugabe von aus Hühnerndarm isoliertem Mukus in signifikanter und dosisabhängiger Art und Weise. Aviärer Dickdarmmukus reduziert die Internalisationeffizienz um 54\% (+/-18\%) $(\mathrm{P}=0.035)$, aviärer Dünndarmmukus sogar um 98\% (+/- 2\%) $(\mathrm{P}=0.00)$. Humaner Mukus zeigt hingegen nicht nur keinerlei derartigen protektiven Effekt, er erhöht sogar die Internalisationsraten gegenüber primären Zellen um $35 \%(+/-22 \%)$ (nicht signifikant, $\mathrm{P}=0.61$ ) (Byrne et al. 2007). Dieser Effekt wurde auch gegenüber Caco-2-Zellen in dosisabhängiger Weise beobachtet. Schon 2\%-iger aviärer Mukus reduziert signifikant die Menge internalisierter Bakterien in den Versuchsansätzen (Byrne et al. 2007). Des Weiteren übt aviärer Mukus keinerlei negativen Einfluss auf die Viabilität und Replikationsfähigkeit von Campylobacter jejuni (Byrne et al. 2007, Van Deun et al. 2008) aus. Die Autoren schlussfolgerten, dass aviärer Mukus einen inhibitorischen Einfluss auf die Interaktion von Campylobacter jejuni mit epithelialen Zelloberflächen ausübt (Byrne et al. 2007). Weiterhin vermuteten sie, dass spezifische luminale intestinale Faktoren im aviären Darmmukus, und nicht ein Gewebetropismus, den klinisch asymptomatischen Campylobacter-Kommensalismus bei Hühnern begründen. Zum gegenwärtigen Zeitpunkt ist jedoch noch nicht bekannt, welche Mukuskomponente die Virulenz von Campylobacter jejuni in dieser Studie reduzierte. Frühere Studien mit INT407 Zellen legten einen Einfluss von spezifischen sekretorischen IgA-Immunglobulinen bei der Blockierung der zellulären Adhärenz von Campylobacter nahe. Dies scheint jedoch unwahrscheinlich, da trotz reduziertem Invasionsvermögen kein Einfluss auf die bakterielle Viabilität ausgeübt wurde und der in den Experimenten verwendete Mukus von Hühner stammte, welche in biologisch überwachten Aufzuchtstationen dem Bakterium Campylobacter jejuni bisher nicht ausgesetzt waren (Byrne et al. 2007).

Aviärer und menschlicher Mukus differieren hinsichtlich Aufbau und Struktur in vielerlei Hinsicht. So könnten Unterschiede in Mukusstruktur, Faltung und Glykolisierung sowie den assoziierten Molekülen und Elektrolyten zu einer Art Trapping-Effekt im Hühnermukus 
führen. Auch besitzen Hühner einen niedrigeren pH-Wert im Intestinaltrakt (pH 5,7-6,4) als Menschen, welcher Beweglichkeit und Virulenz beeinflussen könnte (Alm et al. 1993, Szymanski et al 1995, Byrne et al. 2007). Der Mukus wurde in den oben zitierten Experimenten jedoch gepuffert und auf einen neutralen $\mathrm{pH}$-Wert eingestellt (Byrne et al. 2007). Auch der Einfluss der begleitenden regionalen Mikroflora im Hühnerdarm sollte nicht außer Acht gelassen werden, jedoch trat eine intestinale pathologische Reaktion selbst bei experimenteller Infektion von eintägigen Hühnchen nur äußerst selten auf (Beery et al. 1988).

Weitere tierexperimentelle Studien zeigten in der Folgezeit (McAuley et al. 2007), dass auch Zelloberflächenmucine (MUC) eine ebenfalls kritische Komponente in der mukosalen Abwehr gegen Campylobacter jejuni spielen könnten. Diese transmembranären Glycoproteine werden an den apikalen Oberflächen aller mukosalen epithelialen Zellen exprimiert. Beim Menschen wurden bisher 10 Mucingene identifiziert und multiple Gene werden in infektionsgefährdeten Geweben exprimiert. Es wird angenommen, dass die Zelloberflächenmucine auf zwei Ebenen an der Wirtsabwehr der Infektion beteiligt sind:

Zum einen agieren sie als freisetzbare Köderliganden für bakterielle Adhesine und limitieren damit die Anlagerung von Pathogenen an andere Zelloberflächenmoleküle und folglich deren Invasion. Damit könnte es sich bei ihnen eventuell um die oben genannte unbekannte Mukuskomponente handeln. Zum anderen wird angenommen, dass die cytoplasmatische Domäne der Zelloberflächenmucine nach Freisetzung der extrazellulären Domäne durch Translokation zu den Mitochondrien und zum Nukleus, durch Bindung an die regulatorische Untereinheit von p53, die intrinsischen Signalwege der Apoptose inhibiert (McAuley et al. 2007). MUC1exprimierende intestinale Zellen zeigen in vitro erhöhte Widerstandskraft gegenüber Cdt im Vergleich zu MUC1-negativen Mutanten (McAuley et al. 2007).

Polymorphismen der Mucingene sowie der verantwortlichen Genen für Regulation der Glycosyltransferasen, welche die Komplexen Kohlenhydrate bereitstellen, oder der Gene, die Mucinproduktion und -sekretion regulieren, könnten einige Individuen für akute Infektion oder chronische Persistenz prädisponieren (McAuley et al. 2007) oder die in-vivo-Resistenz aviärer Epithelzellen gegenüber den apoptotischen Enflüssen von Campylobacter jejuni erklären, obwohl die zytoplasmatischen Domänen der Zelloberflächenmucine zwischen verschiedenen Spezies in der Regel hochkonserviert sind (McAuley et al. 2007) und beide von uns verwendeten Zelltypen sich gegenüber dem Toxin als gleichermaßen empfindlich erwiesen. 
Mehrere Autoren vermuten schließlich einen immunmodulatorischen Einfluss von Campylobacter jejuni auf die Abwehrfunktionen des Wirtes als Ursache seiner speziesspezifischen Wirkung. Schon frühe Untersuchungen legten nahe, dass Campylobacter jejuni die Immunantwort von Hühnern durch Induktion von Apoptose in Lymphozyten herunterreguliert und deshalb dort keine Krankheitszeichen verursacht. Dies deckt sich mit der Annahme, dass die inflammatorische Antwort des Wirtes einen Großteil der klinischen Symptomatik verursacht (Ketley 1997).

Hochinvasive Campylobacter-Wildtypisolate zeigen in vivo sehr gute und langandauernde Kolonisationsfähigkeiten, führen zu einem IgG-Anstieg bei Hühnern, und können sogar aus Lebergewebe reisoliert werden, obwohl sie keine klinische Beeinflussung im Sinne von Diarrhoe oder inflammatorische Reaktion hervorrufen (Hänel et al. 2004). Campylobacter jejuni scheint also im Sinne eines kommensalen Bakteriums in der Lage zu sein, die Immunantwort des Huhnes zu manipulieren, um eine destruktive inflammatorische Antwort des Darmes zu verhindern. Hierfür verantwortlich gemacht wurde schon in frühen Studien ein Proteinase-sensibles, membranassosziiertes Protein (Zhu et al. 1999), bei welchem es sich höchstwahrscheinlich um Cdt handelt. Eine spezifische, auf bestimmte Zellpopulationen eingegrenzte Wirkung des Toxins wäre daher am ehesten durch selektive Exposition bzw. Aufnahme zu erklären, wie sie z.B. im Falle von zellspezifischen Rezeptormechanismen gegenüber den Untereinheiten CdtA und CdtC auftreten könnte. Für eine solche Rezeptorspezifität gegenüber Cdt von Campylobacter jejuni gibt es zum jetzigen Zeitpunkt jedoch keinerlei Anhaltspunkte. $\mathrm{CD}_{4+}$ und $\mathrm{CD}_{8+}$ Hühnerlymphozyten zeigen in Zellkulturexperimenten keine signifikanten Unterschiede bezüglich der Apoptose-Rate, auch alle anderen Hühnerlymphozytenpopulationen erscheinen sensibel (Zhu et al. 1999).

Menschliche Immunzellen, sowohl Jurkat T-Lymphozyten als auch B-Lymphozyten (Hickey et al. 2000, Cortes-Bratti et al. 2001), erweisen sich ebenfalls als hochsensibel gegenüber dem Toxin. So wird vermutet, dass Cdt von H. ducreyi und A. actinomycetocomitans durch seine suppressiven Effekte auf die T-Zellantwort des Wirtes mit einer lokalen oder systemischen Immunparalyse zur Aufrechterhaltung chronischer Infektionen wie dem Ulcus molle und Parodontose beiträgt (Cortes-Bratti et al. 2001). Auch für die akute selbstlimitierende Campylobacter-Enteritis soll ein Apoptose-induzierender Effekt von Cdt auf Lymphozyten zur Pathogenese beitragen. Die Selektivität der Wirkung ließe sich hierbei zu einem gewissen Grade auch dadurch erklären, dass $C d t$ in primären Lymphozyten keinen Zellzyklusarrest mit 
konsekutiver Apoptose induziert, sofern diese nicht zuvor durch Mitogene aktiviert worden sind (Shenker et al. 2001). Somit wird keine oder nur eine geringere Wirkung auf nichtaktivierte und nicht-proliferierende Immunzellen hervorgerufen.

Für die beobachtete Apoptose-Induktion von infizierten humanen Makrophagen wird hingegen ein Caspase-1- und Cdt-unabhängiger Mechanismus angenommen, welcher es der Wirtsabwehr erlaubt, durch Antigenpräsentation und Verhinderung einer Vermehrung des Keimes in einer Nische jenseits des Immunsystems dem pathogenetischen Ziel einer Ausbreitung über das Intestinum hinaus entgegenzuwirken (Siegesmund et al. 2004).

Weiterhin wirkt Cdt gegenüber dem Hühnerimmunsystem nicht immunogen. Beim Menschen sind nach gesicherter, klinisch manifester Infektion in der Regel nicht nur spezifische CdtAntikörper-Spiegel nachweisbar, diese sind auch höher als in einer nicht akut infizierten Kontrollgruppe. Das Huhn zeigt hingegen bei Kolonisation keine Cdt-Antikörper, jedoch Antikörper gegen verschiedene andere Campylobacter-Antigene (AbuOun et al. 2005).

Ein selektiver, spezies-abhängiger Effekt der Toxinwirkung in vivo erscheint nach diesen Erkenntnissen somit natürlich plausibel und denkbar. Die postulierten spezies-spezifischen Unterschiede in den Regulaturmechanismen des Immunsystems, welche in die selektive Induktion von Apoptose in bestimmten Subpopulationen von Immunzellen münden, sind jedoch viel zu komplex, als dass man sie nur durch Untersuchungen unter Zellkulturbedingungen nachvollziehen könnte. Vielmehr steht die Forschung bei Campylobacter jejuni trotz verschiedener theoretischer Überlegungen und vielversprechender Versuchsansätze diesbezüglich noch am Anfang und es bedarf noch einer Reihe weiterer Untersuchungen, sowohl auf Zellkulturebene als auch mit einem passenden Kleintiermodell. 


\section{$5 \quad$ Zusammenfassung}

Während Hühner und andere Vögel oft klinisch inapparent mit Campylobacter jejuni im Darm kolonisiert sind, führt die Infektion des Menschen mit diesem Erreger meistens zu einer Durchfallsymptomatik. Es sollte deshalb in dieser Arbeit die Hypothese überprüft werden, ob eine Adaptation zwischen bestimmten bakteriellen Isolaten und ihrem Wirt für die unterschiedlichen Folgen einer Campylobacter-Infektion verantwortlich ist.

Als für die Virulenz wichtige bakterielle Faktoren sind unter anderem (i) die Invasionsfähigkeit von Campylobacter jejuni, sowie (ii) das die Wirtszellapoptose induzierende Cytolethal Distending Toxin (Cdt) bekannt. Es sollte daher in in-vitro-Modellen geklärt werden, ob sich die bakterielle Invasivität, die induzierten apoptotischen Effekte und die Transkription von Cdt bei Verwendung von aviären und humanen Campylobacte-jejuniIsolaten in Abhängigkeit von den verwendeten aviären und humanen Wirtszellen unterscheiden. Hierzu wurden mehrere aviäre und humane Isolate, sowie Referenzstämme von Campylobacter jejuni in Kokultur mit humanen Caco-2-Zellen und Hühnerdarmepithelzellen untersucht. Obwohl eine große interindividuelle Variabilität zwischen den untersuchten Campylobacter-Isolaten sowohl hinsichtlich ihres Invasionsvermögens als auch hinsichtlich der in der Wirtszelle induzierten Apoptose nachweisbar war, konnte unter den gewählten in-vitro-Bedingungen keine Assoziation zwischen der Herkunft der untersuchten Campylobacter-Isolate (aviär oder human) und der infizierten Wirtszellen (aviär oder human) im Sinne einer Anpassung der cdt-Transkription des Bakteriums oder der in der Wirtszelle induzierten Apoptose nachgewiesen werden. Daher scheinen weder Unterschiede in der Invasionsfähigkeit oder in der Cdt-Produktion von Campylobacter jejuni noch eine größere zellspezifische Empfänglichkeit für das unterschiedliche infektionsbiologische Verhalten dieser Bakterienart im Huhn im Vergleich zum Menschen eine zentrale Rolle zu spielen.

Andere mögliche pathogenetische Faktoren, wie z. B. die unterschiedliche Körpertemperatur $\left(42^{\circ} \mathrm{C}\right.$ im Huhn versus $37^{\circ} \mathrm{C}$ im Menschen), die Muzinzusammensetzung und immunmodulatorische Prozesse sollten Anlass für weitergehende Untersuchungen sein. 


\section{$6 \quad$ Literaturverzeichnis}

Abu-Halaweh M, Bates J, Patel KKC (2005): Rapid detection and differentiation of pathogenic Campylobacter jejuni and Campylobacter coli by real-time PCR. Res Microbiol $\underline{156}, 107-114$

AbuOun M, Manning G, Cawthraw SA, Ridley A, Ahmed IH, Wassenaar TM, Newell DG (2005): Cytolethal Distending Toxin (CDT)-Negative Campylobacter jejuni Strains and AntiCDT Neutralizing Antibodies are induced during human infection but not during colonization in chickens. Infect Immun $\underline{73}, 3053-3062$

Allos BM (2001): Campylobacter jejuni infections: update on emerging issues and trends. Clin Infect Dis $\underline{32}, 1201-1206$

Alm RA, Guerry P, Trust TJ (1993): The Campylobacter sigma 54 flaB flagellin promotor is subject to environmental regulation. J Bacteriol $\underline{175}, 4448-4455$

Bang DD, Scheutz F, Ahrens P, Pedersen K, Blom J, Madsen M (2001): Prevalence of cytolethal distending toxin (cdt) genes and CDT production in Campylobacter spp. Isolated from Danish broilers. J Med Microbiol 50, 1087-1094

Beery JT, Hugdahl MB, Doyle MP (1988): Colonization of gastrointestinal tracts of chicks by Campylobacter jejuni. Appl Environ Microbiol 54, 2365-2370

Bereswill S, Kist M (2002): Molecular microbiology and pathogenesis of Helicobacter and Campylobacter updated: a meeting report of the $11^{\text {th }}$ conference on Campylobacter, Helicobacter and related organisms. Mol Microbiol 45, 255-262

Biswas D, Itoh K, Sasakawa C (2003): Role of microfilaments and microtubules in the invasion of INT-407 cells by Campylobacter jejuni. Microbiol Immunol 47, 469-473

Black RE, Levine MM, Clements ML, Hughes TP, Blaser MJ (1988): Experimental Campylobacter jejuni infections in humans. J Infect Dis $\underline{157,472-479}$ 
Blaser MJ: Campylobacter and related species; in: Priciples and Practice of infectious Diseases; hrsg. v. Mandell GL, Benett JE, Dolin R; Churchill Livingstone, Inc., New York, $1995,1948-1956$

Boesze-Battaglia K, Besack D, McKay T, Zekavat A, Otis L, Joradan-Sciutto K, Shenker BJ (2006): Cholesterol-rich membrane microdomains mediate cell cycle arrest induced by Actinobacillus actinomycetocomitans cytolethal-distending toxin. Cell Microbiol $\underline{8}, 823-836$

Byrne CM, Clyne M, Bourke B (2007): Campylobacter jejuni adhere to and invade chicken intestinal epithelial cells in vitro. Microbiology $\underline{153}, 561-569$

Carrillo CD, Taboada E, Nash JHE, Lanthier P, Kelly J, Lau PC, Verhulp R, Mykytczuk O, Sy J, Findlay WA, et al. (2004): Genome-wide Expression Analyses of Campylobacter jejuni NCTC11168 Reveals Coordinate Reguation of Motility and Virulence by flhA. J Biol Chem $\underline{279}, 20327-20338$

Coote JG, Stewart-Tull DES, Owen RJ, Bolton FJ, Siemer BL, Candlish D, Thompson DH, Wardlaw AC, On SLW, Candlish A, Billcliffe B, Jordan PJ, Kristiansen K, Borman P (2007): Comparison of virulence-associated in vitro properties of typed Campylobacter jejuni from different sources. J Med Microbiol 56, 722-732

Corry JE, Atabay HI (2001): Poultry as a source of Campylobacter and related organisms. Symp Ser Soc Appl Microbiol 30, 96S-114S

Cortes-Bratti X, Chaves-Olarte E, Lagergard T, Thelestam M (2000): Cellular internalisation of cytolethal distending toxin from Haemophilus ducreyi. Infect Immun $\underline{68}, 6903-6911$

Cortes-Bratti X, Karlsson C, Lagergard T, Thelestam M, Frisan T (2001): The Haemophilus ducreyi Cytolethal Distending Toxin Induces Cell Cycle Arrest ans Apoptosis via the DNA Damage Checkpoint Pathways. J Biol Chem 276, 5296-5302

Elsinghorst EA (1994): Measurment of Invasion by Gentamicin Resistance. Methods Enzymol 236, 405-420 
Elvers KT, Park SF (2002): Quorum sensing in Campylobacter jejuni: detection of a luxS encoded signaling molecule. Microbiology $\underline{148}, 1475-1481$

Elwell CA, Dreyfus LA (2000): Dnase I homologous residues in CdtB are critical for cytolethal distending toxin-mediated cell cycle arrest. Mol Microbiol 37, 952-963

Epidemiol Bull, Robert Koch Institut, $\underline{36 / 2007}$

Epidemiol Jahrb, Robert Koch Institut, 2009

Everest PH, Goosens H, Butzler JP, Lloyd D, Knutton S, Ketley JM, Williams PH (1992): Differentiated Caco-2 cells as a model for enteric invasion by Campylobacter jejuni and $\mathrm{C}$ coli. J Med Microbiol 37, 319-325

Eyigor A, Dawson KA, Langlois BE, Pickett CL (1999): Detection of cytolethal distending toxin activity and cdt genes in Campylobacter spp. Isolated from chicken carcasses. Appl Environ Microbiol $\underline{65}, 1501-1505$

Fauchere JL, Rosenau A, Veron M, Moyen EN, Richard S, Pfister A (1986): Association with HeLa cells of Campylobacter jejuni and Campylobacter coli isolated from human feces. Infect Immun $\underline{54}, 283-287$

Fischer SF, Schwarz C, Vier J, Häcker G (2001): Characterization of antiapoptotic activities of Chlamydia pneumonia in human cells. Infect Immun 69, No.11, 7121-7129.

Friedman CR, Neimann J, Wegener HC, Tauxe RV: Epidemiology of Campylobacter jejuni infections in the United States and other industrialized nations; in: Campylobacter $2^{\text {nd }}$ Edition; hrsg. v. Nachamkin I, Blaser MJ; ASM Press, Washington 2000, 121-138

Gaynor EC, Wells DH, MacKichan JK, Falkow S (2005): The Campylobacter jejuni stringent response controls specific stress survival and virulence-associated phenotypes. Mol Microbiol 56, 8-27 
Ge Z, Schauer DB, Fox JG (2008): In vivo virulence properties of bacterial cytolethaldistending toxin. Cell Microbiol $\underline{10}, 1599-1607$

Guerra L, Teter K, Lilley BN, Stenerlöw B, Holmes RK, Ploegh HL, Sandvig K, Thelestam M, Frisan T (2005): Cellular internalisation of cytolethal distending toxin: a new end to a known pathway. Cell Microbiol , 921-934

Hänel I, Müller J, Müller W, Schulze F (2004): Correlation between invasion of Caco-2 eukaryotic cells and colonization ability in the chick gut in Campylobacter jejuni. Vet Microbiol 101, 75-82

Hänel I et al. (2006): persönliche Mitteilung, Jena

Hänel I, Borrmann E, Müller J, Alter T (2007a): Relationships between bacterial genotypes and in vitro virulence properties of Campylobacter jejuni and Campylobacter coli isolated from turkeys. J Appl Microbiol 102, 433-441

Hänel I et al (2007b): persönliche Mitteilung zum Invasionstest, einfache Versuchdurchführung, Jena

Heywood W, Henderson B, Nair SP (2005): Cytolethal distending toxin: creating a gap in the cell cycle. J Med Microbiol 54, 207-216

Hickey TE, McVeigh AL, Scott DA, Michielutti RE, Bixby A, Carrol SA, Bourgeois AL, Guerry P (2000): Campylobacter jejuni Cytolethal Distending Toxin Mediates Release of Interleukin-8 from Intestinal Epithelial Cells. Infect Immun $\underline{68}, 6535-6541$

Hickey TE, Majam G, Guerry P (2005): Intracellular Survival of Campylobacter jejuni in Human Monocytic cells and Induction of Apoptotic Death by Cytolethal Distending Toxin. Infect Immun $\underline{73}$, 5194-5197

Hof H, Dörries R: Duale Reihe: Medizinische Mikrobiologie, 3. Auflage; Georg Thieme Verlag, Stuttgart 2005, 436-437 
Hu L, Kopecko DJ (1999): Campylobacter jejuni 81-176 Associates with Microtubles and Dynein during Invasion of Human Intestinal Cells. Infect Immun $\underline{67}, 4171-4182$

Hu X, Nesic D, Stebbins CE (2006): Comparative Structure-Function Analysis of Cytolethal Distending Toxins. Proteins $\underline{62}, 421-434$

Jain D, Prasad KN, Sinha S, Hussain N (2008): Differences in virulence atributes between cytolethal distending toxin positive and negative Campylobacter jejuni strains. J Med Microbiol 57, 267-272

Jain D, Prasad KN, Sinha S, Vishwakarma AL (2009): Cell cycle arrest \& apoptosis of epithelial cell line by cytolethal distending toxin positive Campylobacter jejuni. Indian J Med Res $\underline{129}, 418-423$

Jeon B, Itoh K, Ryu S (2005): Promotor analysis of cytolethal distending toxin genes (cdtA, B and C) and effect of a luxS mutation on CDT production in Campylobacter jejuni. Microb Immunol $\underline{49}, 599-603$

Johnson WM, Lior H (1988): A new heat-labile cytolethal distending toxin (CDT) produced by Campylobacter spp. Microb Pathog $\underline{4}, 115-126$

Kalischuk LD, Inglis GD, Buret AG (2007): Strain-dependent induction of epithelial cell oncosis by Campylobacter jejuni is correlated with invasion ability and is independent of cytolethal distending toxin. Microbiology 153, 2952-2963

Ketley JM (1997): Pathogenesis of enteric infection by Campylobacter. Microbiology 143, 521

Khanna MR, Bhavsar SP, Kapadnis BP (2006): Effect of temperature on growth and chemotactic behaviour of Campylobacter jejuni. Lett Appl Microbiol 43, 84-90

Kist M: The historical background to Campylobacter infection: new aspects; in: Campylobacter III; hrsg. v. Pearson AD, Skirrow MB, Lior H, Rowe B; Public Health laboratory service, London UK 1985, 23-47 
Konkel ME, Corwin MD, Joens LA, Cieplak jr. W (1992): Factors that influence the interaction of Campylobacter jejuni with cultured mammalian cells. J Med Microbiol 37, 3037

Konkel ME, Joens LA, Mixter PF: Molecular characterization of Campylobacter jejuni virulence determinants; in : Campylobacter $2^{\text {nd }}$ Edition; hrsg. v. Nachamkin I, Blaser MJ; ASM Press, Washington 2000, 217-240

Korolik V, Alderton MR, Smith SC, Chang J, Coloe PJ (1998): Isolation and molecular analysis of colonising and non-colonising strains of Campylobacter jejuni and Campylobacter coli following experimental infection of young chickens. Vet Microbiol $\underline{60}$, 239-249

Lastovica AJ, Skirrow MB: Clinical significance of Campylobacter and related species other than Campylobacter jejuni and C. coli; in: Campylobacter $2^{\text {nd }}$ Edition; hrsg. v. Nachamkin I, Blaser MJ; ASM Press, Washington 2000, 89-120

Lindmark B, Romipikuntal PK, Vaitkevicius K, Song T, Mizunoe Y, Uhlin BE, Guerry P, Wai SN (2009): Outer membrane vesicle-mediated release of cytolethal distending toxin (CDT) from Campylobacter jejuni. BMC Microbiol 2009, $\underline{9}, 220$

McAuley JL, Linden SK, Pang CW, King RW, Pennington HL, Gendler SJ, Florin TH, Hill GR, Korolik V, McGuckin MA (2007): MUC1 cell surface mucin is a critical element of the mucosal barrier to infection. J Clin Invest $\underline{117}, 2313-2324$

Meinersmann RJ, Rigsby WE, Stern NJ, Kelley LC, Hill JE, Doyle MP (1991): Comparative study of colonizing and noncolonizing Campylobacter jejuni. Am J Vet Res $\underline{52}$, 1518-1522

Mülhardt C: Der Experimentator: Molekularbiologie/Genomics, 3.Auflage; Spektrum Akademischer Verlag, Heidelberg/Berlin 2002, 50-55

Nachamkin I, Allos BM, Ho TW: Campylobacter jejuni infection and the association with Guillain-Barre'syndrome; in: Campylobacter $2^{\text {nd }}$ Edition; hrsg. v. Nachamkin I, Blaser MJ; ASM Press, Washington 2000, 155-175 
Nadeau E, Messier S, Quessy S (2003): Comparison of Campylobacter isolates from poultry and humans: association between in vitro virulence properties, biotypes and pulse-field gel electrophoresis clusters. Appl Environ Microbiol 69, 6316-6320

Nesic D, Hsu Y, Stebbins CE (2004): Assembly and functions of bacterial genotoxin. Nature $\underline{429}, 429-433$

Newell DG, McBride H, Saunders F, Dehele Y, Pearson AD (1985): The virulence of clinical and environmental isolates of Campylobacter jejuni. J Hyg Camb 94, 45-54

Olsvik OK, Wachsmuth K, Morris G, Feeley JC (1984): Genetic probing of Campylobacter jejuni for cholera toxin and Escherichia coli heat-labile enterotoxin. Lancet 1984,1, 449 (Brief)

On SLW, Dorell N, Petersen L, Bang DD, Morris S, Forsythe SJ, Wren BW (2006): Numerical analysis of DNA microarray data of Campylobacter jejuni strains correlated with survival, cytolethal distending toxin and haemolysin analyses. J Med Microbiol 296, 353-363

Parkhill J, Wren BW, Mungall K, Ketley JM, Churcher C, Basham D, Chillingworth T, Davies RM, Feltwell T, Holroyd S, Jagels K, Karlyshew AV, Moule S, Pallen MJ, Penn CW, Quail MA, Rajandream MA, Rutherfod KM, van Vliet AH, Whitehead S, Barrel BG (2000): The complete genome sequence of the food borne pathogen Campylobacter jejuni reveals hypervariable sequences. Nature $\underline{403}, 665-668$

Perlman DM, Ampel NM, Schifman RB, Cohn DL, Patton CM, Aguirre ML, Wang WLL, Blaser MJ (1988): Persistent Campylobacter jejuni infections in patients infected with human immunodeficiency virus (HIV). Ann Intern Med 108, 540-546

Petersen L, Larsen TS, Ussery DW, On SLW, Krogh A (2003): RpoD promotors in Campylobacter jejuni exhibit a strong periodic signal instead of a -35 box. J Mol Biol $\underline{326}$, $1361-1372$ 
Pickett CL, Pesci EC, Cottle DL, Russell G, Erdem AN, Zeytin H (1996): Prevalence of cytolethal distending toxin production in Campylobacter jejuni und relatedness of Campylobacter cdtB genes. Infect Immun $\underline{64}$, 2070-2078

Pickett CL: Campylobacter toxins and their role in pathogenesis; in: Campylobacter $2^{\text {nd }}$ Edition; hrsg. v. Nachamkin I, Blaser MJ; ASM Press, Washington 2000, 179-190

Purdy D, Buswell CM, Hodgson AE, McAlpine K, Henderson I, Leach SA (2000): Characterisation of cytolethal distending toxin (CDT) mutants of Campylobacter jejuni. J Med Microbiol 49, 473-479

Ren Y, Savill J (1998): Apoptosis: the importance of being eaten. Cell Death Differ $\underline{5}$, 563568

Russel RG, Blake jr. DC (1994): Cell Association and Invasion of Caco-2 Cells by Campylobacter jejuni. Infect Immun 62, No.9, 3773-3779

Schulze F, Hänel I, Borrmann E (1998): Formation of cytotoxins by enteric Campylobacter in humans and animals. Zentralbl Bakteriol 288, 225-236

Scott DA, Tribble DR: Protection against Campylobacter infection and vaccine development; in: Campylobacter $2^{\text {nd }}$ Edition; hrsg. v. Nachamkin I, Blaser MJ; ASM Press, Washington 2000, 303-319

Shenker BJ, Hoffmaster RH, Zekavat A, Yamaguchi N, Lally ET, Demuth DR (2001): Induction of apoptosis in human $\mathrm{T}$ cells by Actinobacillus actinomycetocomitans cytolethal distending toxin is a consequence of $\mathrm{G}_{2}$ arrest of the cell cycle. J Immunol $\underline{167}, 435-441$

Shenker BJ, Demuth DR, Zekavat A (2006): Exposure of Lymphocytes to high doses of Actinobacillus actinomycetocomitans Cytolethal Distending Toxin induces rapid onset of Apoptosis-mediated DNA fragmentation. Infect Immun 74, 2080-2092

Shenker BJ, Dlakic M, Walker LP, Besack D, Jaffe E, LaBelle E, Boesze-Battaglia K (2007): A novel mode of action for a microbial-derived immunotoxin: the cytolethal distending 
subunit B exhibits phosphatidylinositol 3,4,5-triphosphate phosphatase activity. J Immunol $\underline{178}, 5099-5108$

Siegesmund AM, Konkel ME, Klena JD, Mixter PF (2004): Campylobacter jejuni infection of differentiated THP-1 macrophages results in interleukin $1 \beta$ release and caspase-1independent apoptosis. Microbiology 150, 561-569

Skirrow MB (1977): Campylobacter enteritis: a “new” disease. Br Med J 1977, 2, 9-11

Skirrow MB, Blaser MJ: Clinical aspects of Campylobacter infection; in: Campylobacter $2^{\text {nd }}$ Edition; hrsg. v. Nachamkin I, Blaser MJ; ASM Press, Washington 2000, 69-88

Smith JL, Bayles DO (2006): The contribution of cytolethal distending toxin to bacterial pathogenesis. Crit Rev Microbiol 32, 227-248

Stintzi A (2002): Gene expression profile of Campylobacter jejuni in response to growth temperature variation. J Bacteriol $\underline{185}$, 2009-2016

Szymanski CM, King M, Haardt M, Armstrong GD (1995): Campylobacter jejuni Motility and Invasion of Caco-2 Cells. Infect Immun 63, No.11, 4295-4300

Taylor WR, Stark GR (2001): Regulation of the G2/M transition by p53. Oncogene 20, 18031815

Thelestam M, Frisan T (2004): Cytolethal distending toxins. Rev Physiol Biochem Pharmacol $\underline{152}, 111-133$

Ueno Y, Ohara M, Kawamoto T, Fujiwara T, Komatsuzawa H, Oswald H, Sugai M (2006): Biogenesis of Actinobacillus actinomycetocomitans cytolethal distending toxin holotoxin. Infect Immun 74, 3480-3487

Ursing JB, Lior H, Owen RJ (1994): Proposal of minimal standards for describing new species of the family Campylobacteraceae. Int J Syst Bacteriol $\underline{44}, 842-845$ 
Vandamme P, Falesen E, Rossau R, Hoste B, Segers P, Tytgat R, DeLey J (1991): Revision of Campylobacter, Helicobacter, and Wolinella taxonomy: emendation of generic descriptions and proposal of Arcobacter gen. nov. Int J Syst Bacteriol 41, 88-103

Van Deun K, Haesebrouck F, Heyndrickx M, Favoreel H, Dewulf J, Ceelen L, Dumez L, Messnes W, Leleu S, Van Immerseel F, Ducatelle R, Pasmans F (2007): Virulence properties of Campylobacter jejuni isolates of poultry and human origin. J Med Microbiol $\underline{56}, 1284-$ 1289

Van Deun K, Pasmans F, Ducatelle R, Flahou B, Vissenberg K, Martel A, Van den Broeck W, Van Immerseel F, Haesebrouck F (2008): Colonization strategy of Campylobacter jejuni results in persistent infection of the chicken gut. Vet Microbiol 130, 285-297

van Vliet AH, Ketley JM (2001): Pathogenesis of enteric Campylobacter infection. Symp Ser Soc Appl Microbiol 30, 45-56

Vinzent R, Dumas J, Picard N (1947): Serious septicemia during pregnancy due to Vibrio, followed by abortion. Bull Acad Nat Med 131, 90-92

Welkos SL (1984): Experimental gastroenteritis in newly-hatched chicks infected with Campylobacter jejuni. J Med Microbiol 18, 233-248

Whitehouse CA, Balbo PB, Pesci EC, Cottle DL, Mirabito PM, Pickett CL (1998): Campylobacter jejuni cytolethal distending toxin causes a G2-phase cell cycle block. Infect Immun $\underline{66}, 1934-1940$

Wösten MM, Boeve M, Koot MG, van Nuene AC, van der Zeijst BA (1998): Identification of Campylobacter jejuni promoter sequences. J Bacteriol 180, 594-599

Zhu J, Meinersmann RJ, Hiett KL, Evans DL (1999): Apoptotic effect of outer membrane proteins from Campylobacter jejuni on chicken lymphocytes. Curr Microbiol $\underline{38}$, 244-249 


\section{Danksagung}

Mein Dank gilt allen, die mich bei der Verwirklichung meiner Promotion unterstützt haben.

Zuerst möchte ich mich herzlich bei meinem Doktorvater Herrn Prof. Dr. med. Uwe Groß für die Überlassung des Themas und die Möglichkeit bedanken, meine Doktorarbeit im Institut für Medizinische Mikrobiologie der Georg-August-Universität Göttingen durchführen zu können. Sein allzeit offenes Ohr für meine Probleme und seine positive Einstellung trotz gelegentlicher Rückschläge haben mich immer wieder ermuntert, am Ball zu bleiben. Sehr hilfreich waren auch die Vorschläge und Korrekturen für die schriftliche Anfertigung meiner Dissertation.

Besonders danke ich weiterhin Herrn Dr. rer. nat. Raimond Lugert für seinen Beistand und seine Geduld bei den PCR-Experimenten, die mich andernfalls an den Rande der Verzweiflung getrieben hätten. Auch danke ich Herrn PD Dr. rer. nat. Carsten Lüder und Frau Dr. med. Valeska Simon, die mich in verschiedenen Abschnitten meines Projekts betreut haben.

Weiterhin danke ich Frau Dr. Ingrid Hänel und Frau Peggy Medner vom Friedrich-LöfflerInstitut Jena für die mehrmalige Zusendung frischer Zellen und die freundlichen Beratung bezüglich des Umgangs mit diesen.

Darüber hinaus geht ein dickes Dankeschön an alle Laborkolleginnen und Kollegen, die mit mir in den letzten dreieinhalb Jahren Freud und Leid geteilt haben. Danke, Anna, Kristin, Diana, Karin, SanSan, Javid, Malik, Hannah, Jonas, Britta, Lili, Nicole (x2), Andrea (x2), Constanze, Olli, Albert, Phillip, Bernd, Marcel. Allen weiteren Mitarbeitern der Arbeitsgruppen Bohne, Lüder, Lugert und Weig möchte ich ebenfalls für die angenehme Arbeitsatmosphäre danken.Weiterhin danke ich Sebastian Gliem für konstruktiven Ideen, Anregungen und Korrekturen zu meiner Arbeit.

Vielen Dank. 


\section{Lebenslauf}

Ich wurde am 15. Dezember 1982 als zweites Kind von Doris und Friedrich Schöttelndreier in Stadthagen, Landkreis Schaumburg geboren.

Dort besuchte ich Grundschule, Orientierungsstufe und Gymnasium und legte im Sommer 2002 meine Abiturprüfung in den Leistungsfächern Mathematik und Chemie sowie den Prüfungsfächern Latein und Geschichte ab.

Nach Ausbildung in Goslar und Herford leistete ich meinen Zivildienst als Rettungssanitäter beim Deutschen Roten Kreuz in den Rettungswachen Stadthagen und Sachsenhagen ab und übte diese Tätigkeit im Anschluss bis zur Aufnahme meines Medizinstudiums an der GeorgAugust-Universität Göttingen im Wintersemester 2003 aus.

Die ärztliche Vorprüfung legte ich im August/September 2005 ab. Es folgten Famulaturen in den Bereichen Allgemein- und Unfallchirurgie, Herz- und Thoraxchirurgie, Allgemeinmedizin, Neurologie, Neuroradiologie und Neurochirurgie.

Seit September 2006 promovierte ich in der Abteilung Bakteriologie am Institut für Medizinische Mikrobiologie der Georg-August-Universität Göttingen unter der Leitung von Herrn Prof. Dr. med. Uwe Groß.

Mein Praktisches Jahr, welches im Februar 2009 begann, absolvierte ich im Klinikum Bremen Mitte (Chirurgie), St. Ansgar Krankenhaus Höxter, Spital Interlaken (jeweils Innere Medizin) und dem Universitätsklinikum Göttingen (Neurologie).

Ich absolvierte den zweiten Abschnitt der Ärztlichen Prüfung im April sowie Juni 2010 und erlangte meine ärztliche Approbation im August 2010.

Seit November 2010 bin ich als Assistenzarzt in der Neurologie der Universitätsmedizin Göttingen tätig. 